\title{
A búza (Triticum aestivum L.) kloroplasztisz lokalizált glutamin-szintetáz enzim allosztérikus szabályozása, a szubsztrátumszintü múködés tanulmányozása
}

Doktori értekezés

NÉMETH EDIT

Témavezető: Dr. Pécsváradi Attila

egyetemi docens

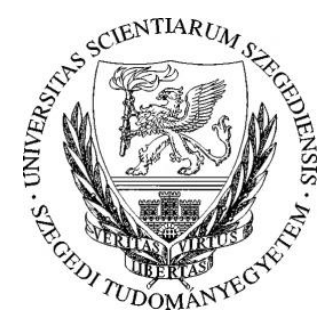

Biológia Doktori Iskola

Szegedi Tudományegyetem

Természettudományi és Informatikai Kar

Növénybiológiai Tanszék

Szeged

2018 


\section{Tartalomjegyzék}

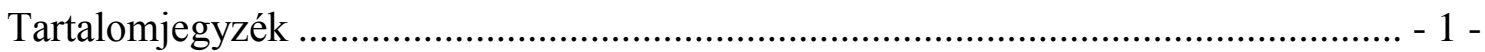

Rövidítések jegyzéke ............................................................................................... 3 -

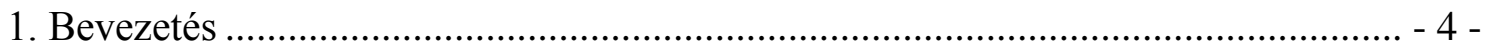

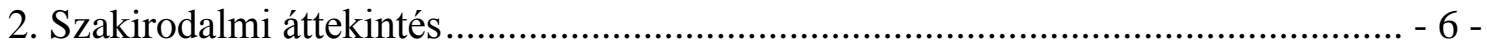

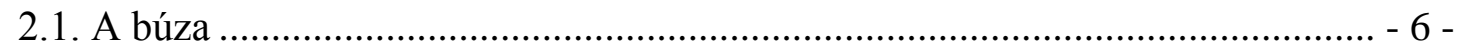

2.2. Allosztérikus kooperativitás................................................................... - 7 -

2.2.1. A szabályozási formák jelentősége, az allosztéria definíciója ................... - 7 -

2.2.2. Az allosztérikus szabályozás formái ....................................................... - 8 -

2.2.3. Az allosztérikus kooperativitás alapmodelljei...................................... - 10 -

2.3. A nitrogén: felvételtől az asszimilációig ...................................................... - 14 -

2.3.1. A nitrogén felvétele, a nitrát redukciója ............................................... - 14 -

2.3.2. A glutamin-szintetáz...................................................................... - 17 -

2.2.2.1. A glutamin-szintetázok szerkezete ................................................ - 17 -

2.2.2.2. A növényi GS jelátvitelben betöltött szerepe és ismert szabályozói . - 21 -

2.2.2.3. A glutamin-szintetáz a növényi anyagcserében ................................ - 22 -

2.2.2.4. A glutamin és glutaminsav szerepe a növényi anyagcserében .......... - 25 -

2.2.2.5. A búza glutamin-szintetázai............................................................ - 27 -

2.4. A mangán és alumínium......................................................................... - 27 -

3. Célkitüzések ........................................................................................... - 31 -

4. Anyagok és módszerek ............................................................................ - 33 -

4.1. Növényi anyag ......................................................................................... - 33 -

4.2. Enzimkivonat készítése ............................................................................... 34 -

4.3. Poliakrilamid gélelektroforézis ................................................................... - 35 -

4.3.1. Natív poliakrilamid gélelektroforézis ................................................. - 35 -

4.3.2. Kétdimenziós poliakrilamid gélelektroforézis ...................................... 37 -

4.4. A glutamin-szintetáz in vitro aktivitás mérése............................................. - 38 -

4.5. A GS aktivitása poliakrilamid gélben ....................................................... - 39 -

4.6. Tisztított GS2 izoenzim izolálása.............................................................. - 39 -

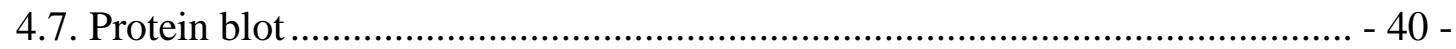

4.8. Poliakrilamid gélek festése, szárítása, dokumentálása.................................. - 42 -

4.9. Fémionok hatásának vizsgálata az in vitro GS aktivitásra............................. - 42 -

4.10. A mangán és magnézium detektálása ........................................................ - 42 -

4.11. Az aktivitásmérések értékelése ................................................................. - 43 -

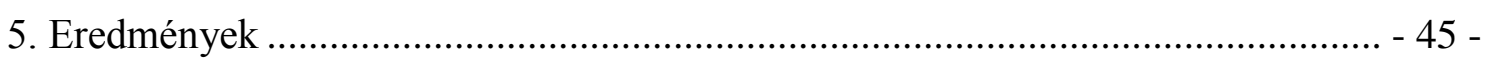


5.1. Szubsztrátumszintủ szabályozás vizsgálata ............................................... - 45 -

5.1.1. Az enzim alegység összetételének vizsgálata.......................................... - 45 -

5.1.2. Szubsztrátumok hatásának vizsgálata................................................ - 46 -

5.1.2.1. A hidroxilamin hatása .................................................................... 47 -

5.1.2.2. Az ATP hatásának vizsgálata ....................................................... - 48 -

5.1.2.3.Glutaminsav telítési kinetikák ........................................................... - 49 -

5.1.3. Végtermékek hatásának vizsgálata..................................................... - 51 -

5.1.3.1. A GMH hatásának vizsgálata .......................................................... - 51 -

5.1.3.2. A glutamin hatásának vizsgálata.................................................. - 52 -

5.1.4. Kis molekulasúlyú allosztérikus effektor jelenlétének vizsgálata ........... - 53 -

5.1.4.1. A hígulás hatása az enzim aktivitására ......................................... - 53 -

5.1.4.2. A pH hatása az enzim aktivitására .................................................. - 55 -

5.1.5. Az allosztérikus modell ........................................................................... - 57 -

5.2. Fémionok hatásának vizsgálata ..................................................................... - 60 -

5.2.1. Magnézium telítődés vizsgálata ........................................................ - 60 -

5.2.2. Alumínium hatásának vizsgálata ....................................................... - 60 -

5.2.3. Mangán hatásának vizsgálata .......................................................... - 61 -

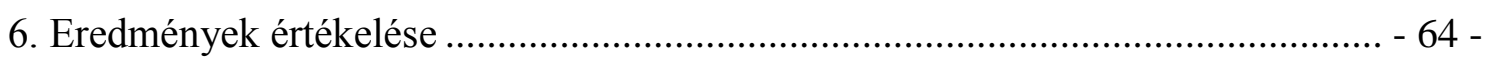

6.1. Az enzim alegység-összetételének vizsgálata ............................................... - 64 -

6.2. Kis molekulasúlyú effektor jelenlétének vizsgálata...................................... - 65 -

6.3. Szubsztrátumszintủ szabályozás vizsgálata ................................................... - 66 -

6.3.1. Végtermékek hatásának vizsgálata.................................................... - 66 -

6.3.2. Szubsztrátumok hatásának vizsgálata................................................... - 67 -

6.3.2.1. A hidroxilamin hatása ....................................................................... 67 -

6.3.2.2. Az ATP hatásának vizsgálata ....................................................... - 68 -

6.3.2.3. A glutaminsav hatása ................................................................... - 69 -

6.4. Fémionok hatása a glutamin-szintetázra .................................................. - 71 -

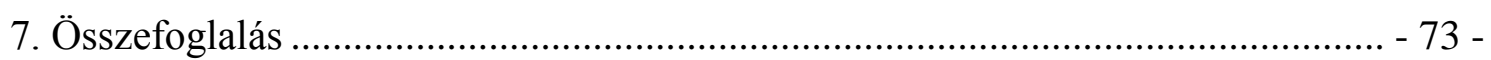

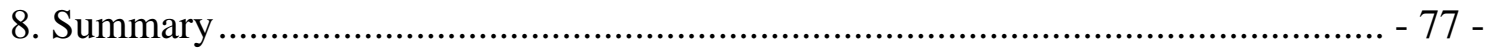

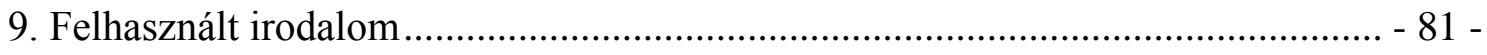

10. Mellékletek ….................................................................................... 90 -

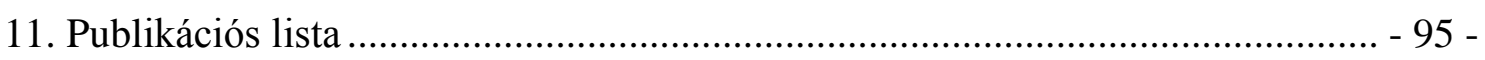

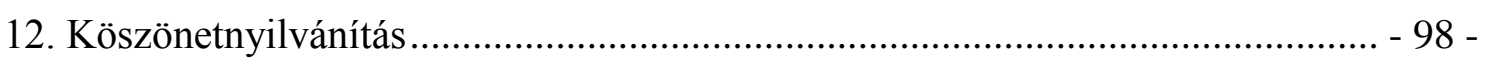




\section{Rövidítések jegyzéke}

AICc: „corrected Akaike Information Criteria” index

Al(III)NTA: nitrilo-triecetsav alumínium komplex

AKT aszpartát-karbamoiltranszferáz

ATP: $\quad$ adenozin-trifoszfát

BCIP: „5-bromo-4-chloro-3-indolyl-phosphate” - 5-bromo-4-kloro3'-indolilfoszfát

CBBG: $\quad$ Coomassie Brilliant Blue G festék

GDH: glutamát-dehidrogenáz

GMH: $\quad \gamma$-glutamil-monohidroxamát

GOGAT: glutamin: 2-oxoglutarát-amintotranszferáz

GS: $\quad$ glutamin-szintetáz enzim (EC.6.3.1.2)

ICP-MS: $\quad$ induktív csatolású plazma tömegspektrometria

KNF Koshland-Némethy-Filmer

LC-MS: folyadékkromatográfia kapcsolt tömegspektrometria

M-M Michaelis-Menten

MWC Monod-Wayman-Changeux

NBT: „nitroblue tetrazolium”-4-nitro-tetrazóliumkék

NR: $\quad$ nitrát-reduktáz

PAGE: poliakrilamid gélelektroforézis

Pi: $\quad$ anorganikus foszfát

Rubisco: ribulóz-1,5-bifoszfát karboxiláz-oxigenáz

SDS: $\quad$ nátrium-dodecil-szulfát

TBS: „tris buffered saline” tris pufferelt sóoldat

TEMED: $\quad \mathrm{N}, \mathrm{N}, \mathrm{N}^{\prime}, \mathrm{N}$-tetrametil-etilén-diamint

Tris: $\quad$ trisz-(hidroximetil)-aminometán

TWEEN 20: $\quad$ polioxietilén(20)-szorbitán-laurát, poliszorbát 20 


\section{Bevezetés}

A búza termesztésének és nemesítésének gyökerei egészen a történelem előtti időkig nyúlnak vissza. A FAO adatai alapján 2017-ben a világ mezőgazdasága élelmezési, takarmányozási és vetőmag termelési célra 2642 millió tonna gabonát termelt, melynek megközelítőleg 30\%-a búzatermelésből származik. Magyarországon csak búzából évente 5 millió tonna terem. A mezőgazdaságban a terméshozamok megtartása vagy növelése érdekében a kimerülő talaj nitrogéntartalmát szerves- és mütrágyázással pótolják. Magyarországon 2011 óta, évente több mint 300 ezer tonna nitrogént juttatnak ki a termőterületekre mütrágya formájában (I. melléklet). Az intenzív talajhasználat, a feleslegben kiszórt nitrogéntartalmú mütrágya kihat a termőtalajok kémiai egyensúlyára, megváltoztatva a felvehető makro- és mikroelemek arányát. Ez hosszútávon rontja a talajok mezőgazdasági hasznosíthatóságát, sőt az extra nitrogén a természetes társulások összetételét is befolyásolja [1]. A hatékonyabb nitrogénasszimilációval rendelkező mezőgazdasági növények használata a környezeti terhelés és a tápanyagpótlás költségeinek csökkentése mellett megnövekedett terméshozamot és nagyobb biomasszát eredményezne. Ilyen növények nemesítéséhez, létrehozásához elengedhetetlen az asszimilációs folyamatok szabályozóinak ismerete, a biokémiai hálózatok dinamikájának felderítése, modellezhetővé tétele.

Munkám során a búza nitrogén-anyagcseréjének egy kiemelten fontos szereplőjével, a glutamin-szintetáz (GS, EC 6.3.1.2) enzimmel foglalkoztam. Egyes kutatók úgy tekintenek erre az enzimre, mint a gabonanövények nitrogén asszimilációjának egy olyan kulcsfontosságú elemére, amely szabályozásának, vagy szerkezetének megváltoztatásával kaput nyithatnak hatékonyabb nitrogén-anyagcserével rendelkező mezőgazdasági növények szerkesztése felé [2].

A GS minden eddig vizsgált fajban jelen van, de jelentős eltéréseket találtak a prokarióta és eukarióta formák müködése között. A prokarióta GS sajátos aktivációja, adenililációja miatt az eukarióta formák tanulmányozásánál is elsősorban az ATP kötőhely vizsgálata került reflektorfénybe [3]. Bár ezeknek a vizsgálatoknak számos GS inhibitor felfedezését köszönhetjük [4,5], jobbára csak korai munkák foglalkoznak nagyobb részletességgel az egyes növényfajok enzimmüködési mechanizmusának jellemzésével, a reakciókörülmények optimalizálásával [6,7]. 
Vizsgálataink során elsősorban a búza kloroplasztiszban lokalizált GS enzimének allosztérikus szabályozásának lehetőségét kerestem Másodsorban, mivel kutatócsoportunk korábbi eredményei kitértek már hasonló vizsgálatokra, megvizsgáltam az alumínium és a mangán kötödésének szerepét az enzim müködésében.

$\mathrm{Az}$ allosztérikus viselkedés vizsgálatára irányuló kísérletekben klasszikus biokémiai módszerekkel tanulmányoztam az enzimműködést. A GS enzim aktivitásának mérésére két módszert fejlesztettek, egy reverz, aminotranszferáz reakciót [8], és egy módosított szintetikus reakciót [9]. Fiziológiai relevanciája miatt az utóbbi módszer használatát részesítettem elönyben. Megvizsgáltam az egyes szubsztrátumok telítési görbéjét regulátor szubsztrátum azonosítása céljából. Tanulmányoztuk a mérésemhez használt rendszerben a GS oligomer stabilitását, és az egyes izoformák alegység összetételének heterogenitását. 


\section{Szakirodalmi áttekintés}

\subsection{A búza}

A fúfélék családjába (Poaceae) tartozó egyszikü kenyérbúza (Triticum aestivum L., a továbbiakban búza) az egyik legfontosabb termesztett gabonanövény világszerte, humán élelmezési és takarmányozási szempontból egyaránt. A napjainkban köztermesztésben lévő fajták többszöri hibridizáció, tudatos szelekció, keresztezés és nemesítés eredményei, melyek hosszas szelekció eredményeként jöttek létre. A nemesítés során homológ génforrásokat, rokon fajokat használtak és használnak fel napjainkban is. A fajták genomja ennek köszönhetően rendkívül összetett. Az allohexaploid búza az A, a B, és a D szubgenomból épül fel, melyek elsődleges génforrásaiként rendre a Triticum urartu, Aegilops speltoides és Aegylops tauschii vadon termő fajokat jelölték meg [10,11].

A búza nemesítése során a magas terméshozam és biomassza termelés mellett kiemelt szempont a biotikus és az abiotikus stressz ellenállóság és a tápanyagok felvételének és hasznosításának hatékonysága. A stresszválaszok akár ugyanazon stressz típusra is eltérőek lehetnek fajtától vagy fejlődési állapottól függően. Szárazság stressz esetén például a levelek öregedése lehet szekvenciális, mely során az idősebb levelek válnak előbb szeneszcenssé [12], vagy nem-szekvenciális, mely során a fiatalabb levelek öregszenek hamarabb [13]. De szekvenciális, korai levélöregedést indukálhat nitrogén hiányos állapot is, mely a kloroplasztiszok fehérjekészletének lebontásával jár együtt [14]. Megfelelő nitrogén ellátottság hiányában megváltozik a búza aminosav tartalma is a floémnedvben és a levelekben egyaránt [15]. Az említett folyamatok indukálják az anyagcsere, a tápanyagforrások és a tápanyag felhasználó helyek közti viszony, jelentős változását, melyet például a GS izoenzimek arányának megváltozása jól jellemez [12].

A búzában a nitrogénanyagcserét érintő változások során az aszparaginsav ellátottság is változik a különböző szövetekben [15]. Az aszparaginsav fontos korai terméke a pirimidin nukleotid bioszintézisnek, melyet az aszpartát-karbamoiltranszferáz (AKT) dolgoz fel, tehát a nitrogénanyagcsere változásai ezt az útvonalat is érinthetik. Az AKT konzervatív aktív helyének köszönhetően búzában és Escherichia coli baktériumban ugyanazt a folyamatot katalizálja, de a két organizmus allosztérikus 
inhibitora már eltérő, búzában uridil-monofoszfát, E. Coliban citozin-trifoszfát [16]. A kísérleti eredmény stresszélettani jelentőségét búzában nem vizsgálták, viszont a búza AKT allosztérikus szabályozása utat nyitott új lehetséges herbicidek fejlesztésének $[17,18]$.

$\mathrm{Az}$ ilyen eltérések mutatják meg milyen nagy szükség van az anyagcserefolyamatok mélyebb megértéséhez a fontosabb enzimek, szabályozó faktorok akár fajonkénti tanulmányozásához, hiszen a fehérjemüködésbeli eltérések ismert fehérjeszerkezetek esetén sem feltétlenül prediktálhatók. Többek között ez tette számunkra indokolttá, hogy búzában a központi szerepet betöltő GS allosztérikus szabályozását vizsgáljuk, annak ellenére, hogy részletes prokarióta modellek állnak rendelkezésünkre.

\subsection{Allosztérikus kooperativitás}

\subsubsection{A szabályozási formák jelentősége, az allosztéria definíciója}

Az élő rendszerekben sokféle szabályozási szint irányítja a biokémiai, élettani folyamatokat. Az egymásra épülő rövid, közép és hosszú válaszidejű reakciók összhangja biztosítja a kiegyensúlyozott életmüködést és az adaptálódást akár a sejt, akár az egyed szintjén.

A szignáltranszdukciós útvonalakon keresztül indukálódó expressziós és poszttranszlációs változások reakciók sorozatát igénylik. Így tehát ezen reakciók idejének összege szükséges az intracelluláris környezet megváltoztatásához, alkalmazkodásához. A hosszú válaszidejü reakciók lehetőséget nyújtanak újabb jelek generálására térben és időben. Ez lehetővé teszi, hogy kisszámú jelgenerátorral számos válasz előidézhető legyen. A kalcium mint másodlagos hírvivő számos folyamatban szerepet játszik. Ezt az teszi lehetővé, hogy a kalciumnak nemcsak a mennyisége, de azzal együtt mennyiségi változásainak amplitúdója is meghatározó a válasz minőségének kiváltásában. Ráadásul a hosszú válaszidejű reakciók esetében a csökkenő vagy növekvő jelintenzitások is értelmezhetők lehetnek, a választ kiváltó küszöbértékek megváltozásával [19].

A hosszú válaszidejü szabályozási formák a kémiai környezet gyors megváltozása esetén viszont nem elegendőek a kiegyensúlyozott intracelluláris müködéshez. Bármely változás, amely egy élő sejtben végbemegy, kémiai reakció(k), 
molekuláris kölcsönhatások következménye. Tehát minden kémiai inger, szignál megjelenése a sejtet elsődlegesen biokémiai szinten érinti. A metabolikus útvonalak hálózatában az egyes ciklusok koordinált működéséhez tehát már fehérje, enzim szinten szükség van „biokémiai kapcsolókra”. A kapcsolók olyan biokémiai szabályozó elemek, melyek müködési mechanizmusa önmagában garantálja a folyamatok rövidtávú összehangolt müködését. Ezek a kapcsolók az allosztérikusan szabályozott fehérjék.

Az allosztéria görög eredetű elnevezése (allos $=$ másik, steros $=$ szilárd, avagy térbeli) a teljes molekulát érintő szerkezeti változások bekövetkezésére utal, a kiváltó októl eltérő helyen. Az allosztérikus fehérjéknek az olyan makromolekulákat nevezték, melyek müködését bizonyos molekulák kötődése olyan módon befolyásolja, hogy az a fehérjemüködés megváltozását okozza, akár a változásokat kiváltó molekula kötőhelyétől eltérő helyen.

Később kritériummá vált, hogy a fehérje monomernek/oligomernek legalább két ligandumkötő hellyel kell rendelkeznie, és hogy a müködésbeli változás elméletileg valamilyen konformációs változáson keresztül valósuljon meg. Emellett az is a korai modellek része volt, hogy az allosztérikusan szabályozott makromolekulának müködésbeli szimmetriával kell rendelkeznie. Az allosztéria újrafogalmazása a bakteriális heptóz-izomeráz működési mechanizmusának feltárásával vált igazán szükségessé. Ennek az enzimnek az allosztérikus viselkedése az eredmények alapján ugyanis nem jár együtt detektálható konformációváltozással [20].

Vannak kísérletek a fogalmak és az egyes szabályozási mechanizmusok osztályozásának aktualizálására [21], de a klasszikus terminológiák elhagyásához még idő kell. A pontos definíció az új felfedezéseknek köszönhetően máig csiszolódik, annak ellenére, hogy az allosztéria kifejezés már több mint fél évszázada használatos, [22].

\subsubsection{Az allosztérikus szabályozás formái}

A szakirodalom alapján abban nincs ellentmondás, hogy az allosztérikus viselkedés a receptorok és enzimek (esetleg folyamatok) önszabályozó müködésének tekinthető, melyet egy effektornak az allosztérikus helyen történő kötődése vált ki. Az allosztérikus hely lehet magában az aktív centrumban, vagy attól távol. Az allosztérikus effektor pedig lehet az adott reakcióra nézve serkentő vagy gátló hatású, amely alapján megkülönböztetünk allosztérikus aktivátorokat és inhibitorokat. 
Az allosztérikus helyek és effektorok bármely típusának kombinációja fennállhat. Ezekre néhány szemléletes példát az 1. ábra tüntet fel [23].

$\mathrm{Az}$ allosztérikus szabályozási mechanizmusok a metabolikus útvonalakban lehetővé teszik a feedback szabályozást. Ekkor egy, a reakciósorban később bekövetkező reakció terméke van hatással saját szintézisére úgy, hogy egy korábban bekövetkező enzimatikus katalízist befolyásol. Aszerint, hogy ez a hatás serkentő vagy gátló, pozitív és negatív feedback mechanizmusokat különböztetünk meg [24].

(a)

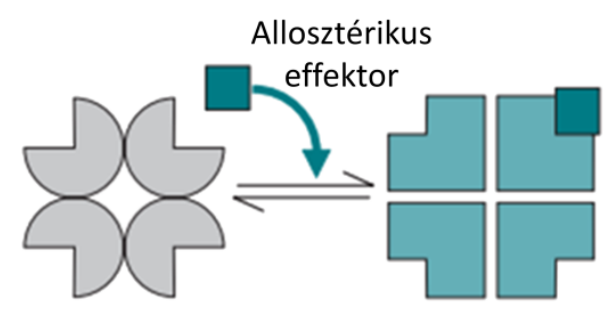

(c)

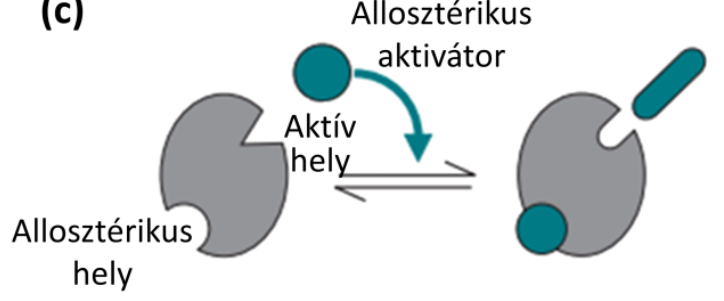

(b)

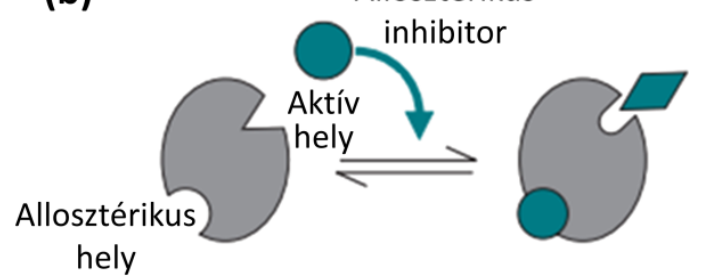

(d)

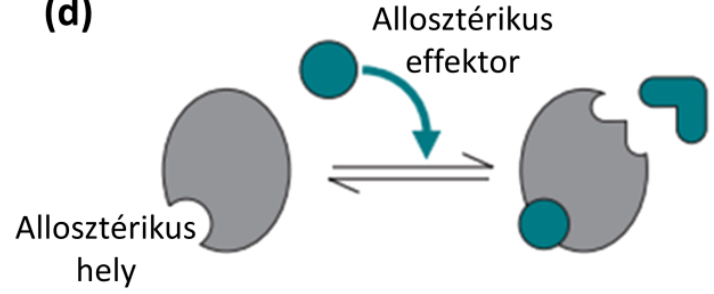

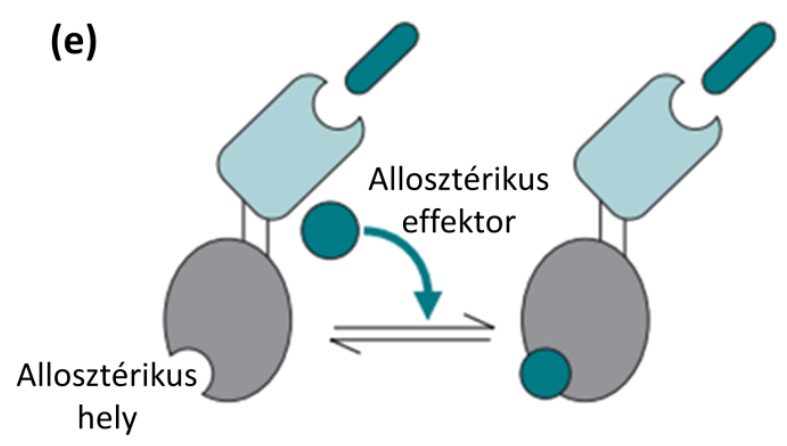

1. ábra: Allosztérikus hatások [23].

(a) Allosztérikus fehérjemüködés a szimmetrikus modell szerint, az alegységek egyszerre, azonos módon változnak meg. (b) Allosztérikus gátlás és (c) allosztérikus aktiváció. (d) Új kötőhely megjelenése allosztérikus effektor hatására. (e) Egy enzim kapcsolódása egy allosztérikus szabályozás alatt álló fehérjéhez. Mivel az enzim aktivitása közvetetten allosztérikus kontroll alatt áll a kapcsolódó fehérje allosztérikus szabályozásának köszönhetően, ez a típusú konstrukció allosztérikus kapcsolóként müködhet. 
Egy adott ligandum ugyanazon fehérje monomeren vagy oligomeren több kötőhelyre is beköthet, és kötődése hatással lehet a többi kötőhely feltöltődésére. Ez az allosztérikus szabályozásnak egy speciális esete, melyet allosztérikus kooperativitásnak nevezünk. Ekkor az allosztérikus effektor az adott fehérje saját szubsztrátuma, vagy liganduma. Következésképpen a kooperatív fehérjék szubsztrátum szaturációs görbéje eltér a hiperbolikustól. Részben ezen eltérés nem artefaktuális eredetének igazolhatósága miatt bonyodalmas volt az allosztérikus kooperativitás bizonyítása és fogalmának honosítása a tudományban [25].

Az allosztérikus kooperativitás kimenetét tekintve lehet pozitív vagy negatív. Pozitív kooperativitás esetén egy szubsztrátum kötődése elősegíti a következő szubsztrátum kötődését. Igen részletesen tárgyalt múlt századi példa erre a hemoglobin oxigénkötésének mechanizmusa, ahol az első oxigén kötődése elősegíti a rákövetkező bekötését. Ebből adódik a szigmoid görbével jellemezhető szaturáció [26,27]. Negatív kooperativitás esetén épp az előzőek ellenkezője játszódik le. A szubsztrátum kötőhelyek feltöltődése akadályozott, mivel az előző szubsztrátum bekötődése gátolja a rákövetkező kötődését az aktív helyen [28]. Az eltérő allosztérikus kooperativitás esetén tapasztalható szaturációs görbéket a 2. ábra szemlélteti.

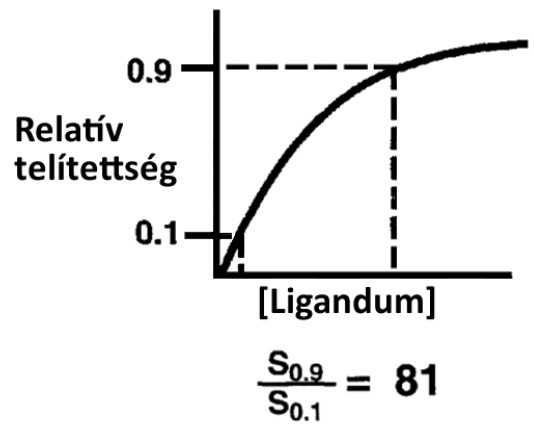

Nincs

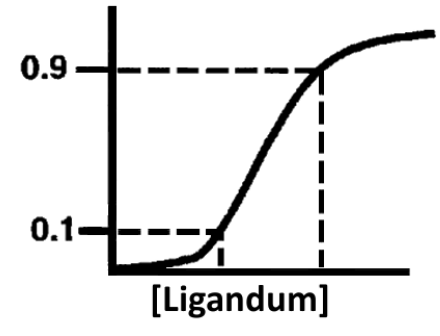

$\frac{S_{0.9}}{S_{0.1}}=4$

Pozitiv

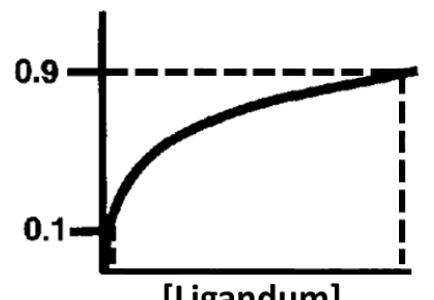

[Ligandum]

$\frac{S_{0.9}}{S_{0.1}}=400$

Negativ

2. ábra: A ligandum kötőhelyek telítődése kooperativitás esetén [28].

Szubsztrátum telítési görbék (a) kooperativitás hiányában, (b) pozitív, (c) és negatív kooperativitás esetén. A telítési görbék alakja és a 90 és 10\%-os szubsztrátum telítettséghez tartozó reakciósebesség aránya $\left(\mathrm{S}_{0,9} / \mathrm{S}_{0,1}\right)$ a kooperativitás függvényében változik.

\subsubsection{Az allosztérikus kooperativitás alapmodelljei}

Az enzimmüködés alapköveit a XX. század elején tették le. Archibald Vivian Hill hemoglobinnal kapcsolatos megfigyeléseit [26] követően született meg Leonor 
Michaelis és Maud Leonora Menten ma már klasszikus szakirodalmi műnek számító közleménye, a Die Kinetik der Invertinwirkung 1913 februárjában [29,30]. Ebben vezették le a ma már Michaelis-Menten (MM) egyenletként emlegetett formulát, mely egy hiperbolikus függvényt definiál:

$$
v_{0}=\frac{V_{\max } \times[S]}{K_{m}+[S]}
$$

Az egyenletben a $v_{0}$ aktuális sebesség értéke $S$ szubsztrátumkoncentrációnál meghatározható a $\mathrm{V}_{\max }$ maximális sebességből és a maximális sebesség feléhez tartozó $\mathrm{K}_{\mathrm{m}}$ szubsztrátumkoncentráció alapján.

Hill bő fél évvel későbbi közleményében [27] a M-M egyenlet egy $n$ hatványkitevő feltüntetésével bővült, az egyenlet így már alkalmassá vált a Hill észleléseit jellemző szigmoid görbe matematikai leírására. Ez a Hill-egyenlet, melynek $n$ hatványkitevője leírója után a Hill koefficiens nevet kapta:

$$
v_{0}=\frac{V_{\max } \times[S]^{n}}{K_{s}^{n}+[S]^{n}}
$$

ahol a maximális sebesség feléhez tartozó szubsztrát koncentrációt az M-M egyenlettől eltérően $\mathrm{K}_{\mathrm{s}}$-sel jelöljük és $n>1$, Vegyük észre, hogy a M-M egyenletben ez a hatványkitevő 1-gyel egyenlő, amely tehát a kooperativitás hiányában lehetséges.

A jelenségek matematikai leírása mellett még szükség volt a fehérjék müködési mechanizmusait leíró elméletekre. Az allosztérikus szabályozás első részletes leírása, és kritérium rendszere Monod, Wyman és Changeux munkája nyomán született meg [31]. A közlemény számos alapfogalmat tisztáz, és bemutatja a szimmetrikus modellt ('concerted model'), melyet a szakirodalom napjainkban MWC-modellként emleget, megalkotói után (3.ábra). A modell megköveteli legalább egy szimmetriatengely meglétét, az allosztérikus ligandum sztereospecifikus kötődését, valamint, hogy a protomerek, a legkisebb már katalitikusan aktív struktúrák konformációját azok kapcsolódása alakítsa ki. Ezek mellett kijelenti, hogy legalább két reverzibilis állapottal kell rendelkeznie az allosztérikus oligomereknek, az átmeneti állapotok megváltozása az affinitás megváltozásával kell, hogy járjon és az állapotátmenetekkel a szimmetriája nem változhat. 
Az MWC modell szerint tehát az egész oligomer összehangoltan, szimmetrikusan változtatja az állapotátmeneket. Az oligomeren belül az egyes protomerek $\mathrm{R}($ Relaxed = laza) és $\mathrm{T}($ Taut $=$ feszes $)$ tranzíciós állapotban lehetnek, melyek közül a T állapot az inaktív. Az MWC modell megmagyarázza az allosztérikus müködést, aktivációt és gátlást, az allosztérikus kötőhelyek bemutatásával, és alkalmazható pozitív kooperativitást mutató rendszerekre. Hiányossága, hogy nem kezeli, valamint homotróp interakciók esetén, vagyis több azonos protomer kapcsolódása esetén eleve elutasítja a negatív kooperativitás lehetőségét.

(a) Szimmetrikus modell

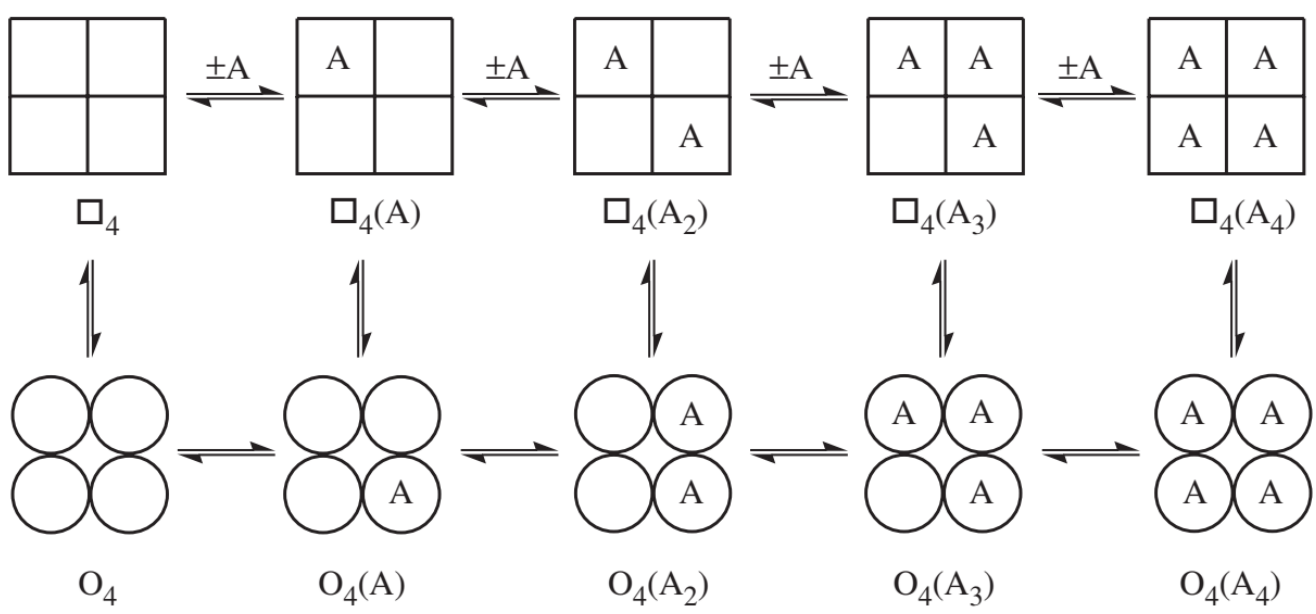

(b) Szekvencális modell

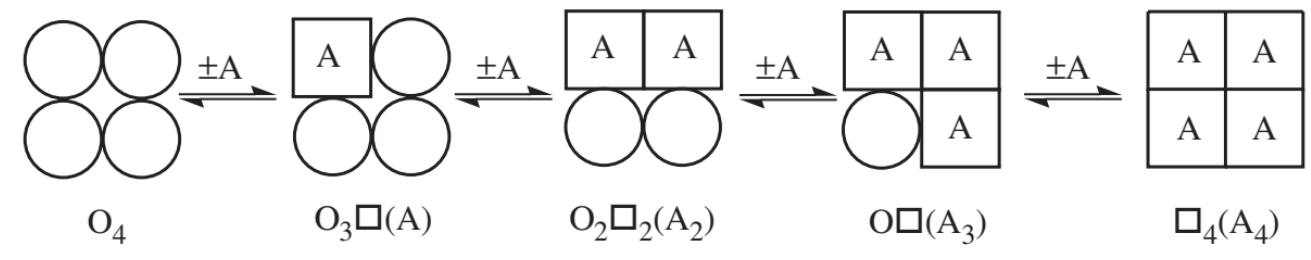

\section{3. ábra: Az allosztérikus kooperativitást magyarázó modellek [24].}

(a) Monod-Wyman-Changeaux-féle szimmetrikus modell: az allosztérikus hatású szubsztrátum (A) kötődésének hatására a protomerek összehangoltan változnak meg. (b) Koshland-Némethy-Filmer-féle szekvenciális modell: a szubsztrátumkötődés hatása csak a kötésben szerepet játszó monomert érinti, nem a teljes oligomert.

Az MWC modell hiányosságait a Koshland-Némethy-Filmer (KNF) modell pótolta, amely már alkalmas volt a negatív kooperativitás leírására. Levitzki és Koshland felfedezte, hogy a CTP-szintáz glutamin szubsztrátum szaturációs görbéje nem hiperbolikus és nem is szigmoidális. A görbe telítődése M-M kinetikához hasonló, de bifázikus, egy töréspont osztja két részre. Ezt egy ligandum által indukált 
konformációváltozással, negatív kooperativitással magyarázták. Emellett megállapították, hogy a fehérje az eltérő ligandumok kötődése esetén más allosztérikus viselkedést mutathat, vagyis többféle kooperativitással rendelkezhet [32].

A KNF modell, más néven szekvenciális modell, már eltekint a szimmetrikus müködéstől. A KNF modell szerint a protomerek állapotváltozásainak nem szükségszerü egyszerre bekövetkeznie, amelyböl adódik, hogy a változások lehetnek aszimmetrikusak. A KNF modell népszerüsítette az úgynevezett „induced-fit”, vagy indukált illeszkedést, amely erősen elrugaszkodik az akkor még népszerü kulcs-zár elmélettől, mely feltételezte, hogy a szubsztrátumok eleve pontosan, szorosan illeszkednek kötőhelyükbe, mint kulcs az ajtózárba. A monomeren/oligomeren bekövetkező változásokat ,induced-fit” esetén a ligandum kötődése okozza, de a ligandum pontos illeszkedését annak kötöhelyén magának a ligandumnak a bekötése indukálja. A modell megengedi a protomerek eltérő ligandum affinitását, ami megmagyarázza például a CTP-szintáz esetében megfigyelt kettős glutamin telítési görbét [33]. Az MWC és KNF modellek közötti különbségeket a 3. ábra mutatja be.

Lewitzki és Koshland összegezte és szemléltette, hogy a Hill koefficiens miként jellemezheti a kooperativitást. A M-M egyenletben, amely a kooperativitás hiányát írja le, ez a kitevő 1-gyel egyenlő, $n>1$ esetén a kooperativitás pozitív, $0<n<1$ esetén a kooperativitás negatív [32]. Tehát ha a Hill koefficiens tört szám, egy gyök függvényt ír le az egyenlet, amely kellően nagy $n$ esetén igen hasonló egy MM-i hiperbolához.

Az „induced-fit” hipotézis vezetett el a „half-site” reaktivitáshoz. Megfigyelték, hogy bizonyos változások csak a protomerek számának felét érintik. A „half-site” reaktivitás során a ligandum kötődése az egyik protomeren olyan konformációt alakít ki a másik protomeren, hogy az már nem képes ligandum kötésére [34]. Napjainkban az ilyen jelenségek leírására a „half-site” reaktivitás és „,half-of-the-sites” reaktivitás kifejezések használatosak. Ifj. Koshland a jelenséget a negatív kooperativitás extrém eseteként írta le [28], amely mára nem példátlan a szakirodalomban [20,35,36]. A protomer fogalma ma már kevéssé használt, így a „half-site” reaktivitás fogalmát gyakran a multimer enzimeket felépítő fehérje monomerek számához kötve értelmezik.

$\mathrm{Az}$ allosztérikus szabályozások, az allosztérikus kooperativitás előnyei önmagukban ritkán mutatkoznak meg. Ezek a mechanizmusok akkor nyernek értelmet, ha a jelenségeket rendszer szinten, összefüggésekben vizsgáljuk. A kooperativitás szubsztrátum regulált mechanizmusai lehetővé teszik különböző érzékenységü, eltérő dinamikával reagáló (ön)szabályozó elemek jelenlétét a biokémiai hálózatokban. 
A pozitív kooperativitás lehetővé teszi egy relatíve szük tartományon belül a gyors telítődést. Ez adott körülmények között egy rendkívül szenzitív szabályozást tesz lehetővé. A negatív kooperativitás viszont lehetővé teszi a lépcsőzetes válaszreakciót, ami egy rendszer stabilitását tudja garantálni, azáltal, hogy viszonylag széles skálán garantálja a fokozatos szaturációt [37,38].

$\mathrm{Az}$ allosztérikus mechanizmusok egyre mélyebb ismerete segít megvilágítani, hogy nem csak a sebesség meghatározó lépések lesznek jelentősek a hálózatot alkotó biokémiai konverziók sorozataiban. A nitrát-reduktáz (NR) a nitrogén asszimiláció folyamatában ilyen sebesség meghatározó lépést végez. Ez az enzim részben ezzel került a nitrogén anyagcsere iránti tudományos érdeklődés középpontjába. Mára viszont az anyagcsereutakat és elemeik szabályozását egymással összefüggésben kell vizsgálnunk. Ez indokolja a nitrogén anyagcsere enzimeinek mélyebb, új szemszögből való vizsgálatát.

\subsection{A nitrogén: felvételtől az asszimilációig}

\subsubsection{A nitrogén felvétele, a nitrát redukciója}

A nitrogén egy jól mobilizálódó esszenciális makroelem, amely aminosavak, fehérjék, növekedésszabályozó anyagok, primer és szekunder metabolitok építőeleme. A megfelelő nitrogén-ellátottság elengedhetetlen a növények megfelelő növekedéséhez, fejlődéséhez, és reprodukciójához. A gabonanövények termésmennyiségének és minőségének szempontjából meghatározó a talajban lévő nitrogén elérhetősége, a felvehető nitrogén mennyisége. A talajoldatból a növények a nitrogént elsősorban nitrát és ammónium formájában veszik fel.

A nitrát felvétele a plazmamembránon átívelő nitrát-transzporterekkel történik. A nitrátfelvételt magas és alacsony affinitású rendszerek látják el. Magas affinitású transzportrendszerből egy konstitutív és egy indukálható transzportrendszert különböztetünk meg. Ezek, bár eltérő $\mathrm{K}_{\mathrm{m}}$ értékkel rendelkeznek, a nitrátfelvételt alacsony nitráttartalmú közegben szolgálják ki. Bőséges nitrátellátottság esetén a harmadik, konstitutív alacsony affinitású transzportrendszer teszi lehetővé a nitrát felvételét. Ennek $K_{m}$ értéke jóval az előzőek fölött van [39-41]. Ezek mellett egy duális csatorna létezése is ismert, a korábban NRT1.1-ként leírt nitrát-transzporter egy poszttranszlációs módosulásnak köszönhetően alacsony és magas affinitású 
nitráttranszportra is képes [42]. A NRT1.1 lúdfüben úgynevezett transzceptor, vagyis nemcsak a nitrát transzportjáért felel, hanem a nitrátellátottság jelzésében is szerepet vállal [43]. A nitrát-transzporterek ezen kívül növényi hormonok (pl.: abszcizinsav, gibberellinek, indol-3-ecetsav) [44] és aminosavak (hisztidin) transzportjában is szerepet játszhatnak $[45,46]$. A növényekben a nitrát irányított felvétele és célhelyre juttatása számos inter- és intracelluláris teret elhatároló membrán felületen kihelyeződött nitrát-transzporteren át szabályozottan valósul meg a xilém elemeken keresztül. A felvett nitrátot a sejtekben a nitrát- és nitrit-reduktáz enzimek redukálják végül ammóniává.

A nitrát ammóniává redukáláshoz az első lépést egy oxidoreduktáz enzim, a NR katalizálja. Növényekben NADH (EC 1.7.1.1. korábban EC 1.6.6.1) [47] és NAD(P)H specifikus (EC 1.7.1.2, korábban EC 1.6.6.2) [48,49] formáit írták le. A nitrát redukció a nitrát asszimilációjának első, egyben sebesség meghatározó lépése. Az enzim monomert egy FAD, egy hem és egy molibdoprotein domén alkotja. Az enzim dimer formában aktív, a dimer szétkapcsolása a NR inaktiválásának egyik lehetséges módja [50,51]. A nitrát redukciója nitritté a citoplazmatikus térben megy végbe, ennek katalízisét a NR a következők szerint hajtja végre:

$$
\mathrm{NO}_{3}^{-}+\mathrm{NAD}(\mathrm{P}) \mathrm{H}+\mathrm{H}^{+} \rightarrow \mathrm{NO}_{2}^{-}+\mathrm{NAD}(\mathrm{P})^{+}+\mathrm{H}_{2} \mathrm{O}
$$

A NR nemcsak nitrát, de klorát és nitrit redukálására is képes [40,52]. A NR a növényekben szolubilis és plazmamembrán kötött formában is előfordul. A gyökér specifikus plazmamembrán kötött forma nitrit redukciójával nitrogén monoxidot, növényi növekedésszabályozó anyagot termel, amely viszont csak a katalizált reakciók körülbelül 1\%-ában képződhet [53,54]. A NO termelésben valószínűleg nagyobb jelentőséggel bírnak más hem csoporttal rendelkező fehérjék [55].

A NR által termelt nitrit transzporteren keresztül, irányított módon jut be a kloroplasztiszba [56,57]. A nitritet a kloroplasztiszon belül egy további oxidoreduktáz, a nitrit-reduktáz (NiR, EC 1.7.7.1) alakítja ammóniumionná:

$$
\mathrm{NO}_{2}^{-}+8 \mathrm{H}^{+}+6 \mathrm{e}^{-} \rightarrow \mathrm{NH}_{4}^{+}+\mathrm{H}_{2} \mathrm{O}
$$


A növények által generált, vagy felvett ammónia vizes közegben protonálódik, ammóniumionként $\left(\mathrm{NH}_{4}^{+}\right)$és kis mennyiségben ammóniaként $\left(\mathrm{NH}_{3}\right)$ van jelen. Míg a töltéssel nem rendelkező ammónia számára a plazmamembrán átjárható, addig az ammóniumion a plazmamembránon ammónium-transzporterek segítségével jut át. $\mathrm{Az}$ ammónium-transzporterek integráns membránfehérjék, melyek transzmembrán doménjei csatornát képeznek a membránon keresztül, lehetővé téve az ammónium uniportját [58]. Növényekben eddig csak magas affinitású ammónium-transzportereket írtak le [59]. Az egységnyi $\mathrm{pH}$ csökkenéssel az $\mathrm{NH}_{3}$ forma mennyisége a tízszeresére nő vizes oldatokban [60]. Mivel az $\mathrm{NH}_{3}$ forma diffúziójának a plazmamembrán nem szab határt, az ammóniumion mielőbbi asszimilációja esszenciális a növényen belüli irányított nitrogén transzporhoz.

A tápanyagfelvétel és a nitrátredukció mellett a pillangósvirágúakra jellemző nitrogénfixálásból, de más biokémiai folyamatokból is jelentős mennyiségü ammónium származik. Fehérjék és aminosavak lebontása, transzaminációs reakciók és a fotorespiráció mitokondriális glicin dekarboxilációs lépése során nagy mennyiségü ammónia szabadul fel. A képződött ammónia asszimilációjáért pedig elsősorban a GS enzim felelös.

Összességében a nitrát felvételében szerepet játszó alacsony és magas affinitású transzportrendszerek biztosítják, hogy a gyökér a növekedése során bármilyen nitráttartalmú talajrétegbe érve folyamatos nitrogénellátást biztosítson. A szervetlen nitrogénformák transzportfolyamataiban és a nitrát redukálásában szerepet játszó fehérjék mennyiségi változásai expressziós és poszttranszlációs szinten jól szabályozottak. A nitrogénellátottság egyértelmüen visszahat a nitrogén felvételére, asszimilációjára, és a jelátviteli rendszereken keresztül a növekedésre és fejlődésre [41,61]. Ezek a folyamatok a hosszútávú alkalmazkodást teszik lehetővé, a kémiai folyamatok reakcióidejéhez mérten igen lassúak. Az ionikus szervetlen nitrogénformák feldúsulása negatívan hat vissza a sejtben végbemenő elektron transzport folyamatok müködésére, így az asszimilációs folyamatok sebessége és irányítottsága esszenciális fontosságú. 


\subsubsection{A glutamin-szintetáz}

A GS enzim minden eddig vizsgált élőlény nitrogén anyagcseréjében kiemelt szerepet tölt be az ammónia asszimilációjában, és az aminosav anyagcserében. Az enzim egy ammóniumiont köt egy glutaminsav molekulához, melynek eredményeképpen egy glutamin jön létre a következő módon:

$$
\mathrm{NH}_{4}{ }^{+}+\text {L-glutamát }+\mathrm{ATP} \rightarrow \text { L-glutamin }+\mathrm{ADP}+\mathrm{Pi}^{+} \mathrm{H}^{+}
$$

Ez az in vivo szintetikus reakció, melynek energiaigényét tehát egy ATP molekula $\gamma$-foszfátjának hasítási energiája fedezi. Emellett az enzimatikus katalízishez kétértékü kationok magnézium és/vagy mangán jelenléte szükséges.

A GS-nak 3 féle katalitikus aktivitását írták le. A fent bemutatott bioszintetikus reakció mellett mesterséges szubsztrátum, hidroxilamin hozzáadásával másik két reakció mehet végbe. A keletkező $\gamma$-glutamil-monohidroxamát $(\mathrm{GMH})$ fotometriás módszerrel detektálható. Az enzim aktivitását elsősorban ezért ezekkel a módszerekkel határozzák meg. A reakciókörülményektől függően ez lehet egy módosított szintézis irányú reakció, kétértékü kation $\left(\mathrm{Mg}^{2+}\right)$ hozzáadásával:

$$
\mathrm{NH}_{2} \mathrm{OH}+\text { L-glutamát }+\mathrm{ATP} \rightarrow \gamma \text {-glutamil-monohidroxamát }+\mathrm{ADP}+\mathrm{P}_{\mathrm{i}}
$$

A másik lehetőség egy reverz reakció, melyet a szakirodalom transzferáz reakcióként emleget. A reakció $\mathrm{Mn}^{2+}, \mathrm{Na}_{3} \mathrm{AsO}_{4}$ alkalmazása mellett játszódik le az alábbi módon:

$$
\text { Glutamin }+\mathrm{NH}_{2} \mathrm{OH}+\mathrm{ADP}+\mathrm{P}_{\mathrm{i}} \rightarrow \gamma \text {-glutamil-monohidroxamát }+\mathrm{NH}_{3}
$$

Mindkét módszer elfogadott, és jól alkalmazható a GS aktivitásának mint élettani paraméternek a mérésére.

\subsubsection{A glutamin-szintetázok szerkezete}

Többféle GS izoenzim alegység összetételéről születtek közlemények a szakirodalomban. Az eddig vizsgált alegységek 12, 10 vagy 8 alegységesek. Az alapján, hogy az alegységek hány aminosavból állnak, három GS típust különböztetünk meg (GSI-III). A GSI és GSIII elsősorban prokariótákra jellemző, 
a GSII-t pedig inkább eukarióta GS-ként tartják számon. Az alegységek kapcsolódását biztosító másodlagos kölcsönhatások az egyes izoformák esetében más felszíneken jönnek létre [62]. Az alegységek közti intra- és intermolekuláris kölcsönhatásokat a 4. ábra szemlélteti.

A GS szerkezet-funkció kapcsolatait prokariótákban nagy részletességgel tanulmányozták. A GS egy több alegységes enzim, melynek aktív centrumát egy alegységpár alakítja ki. A prokarióta GS-ok dodekamerek, melyeket két egymással szembe fordított hatos gyürü alkot. Az egymással szemben elhelyezkedő alegységpárok így hat katalitikus helyet alakítanak ki, melyek az egyik alegység C-terminálisa, és a másik alegység N-terminálisa közt jönnek létre [63]. A szerkezetet hidrofil-hidrofób kölcsönhatások stabilizálják. A kölcsönhatás kialakításában az alegységpár egyik monomerének olyan C-terminális felöli hélixe játszik kulcsszerepet, amely az ellentett oldali alegységbe illeszkedik [64]. A C-terminális végen egy adenililációs hely található, míg az adenililáció megszüntetésében szerepet játszó domént az N-terminálison írták le Escherichia coliban [65].
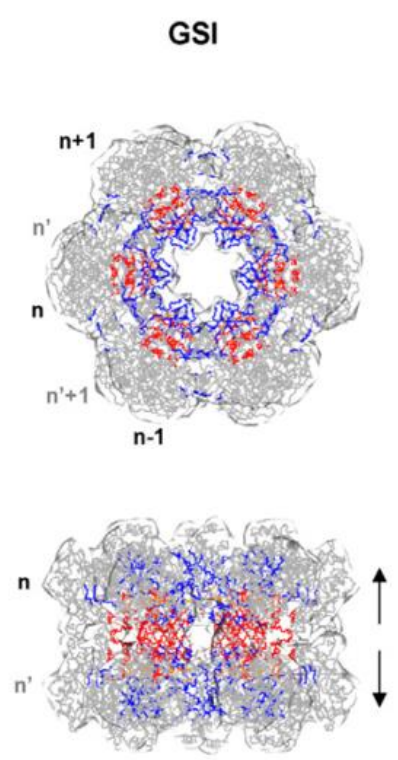

GSII
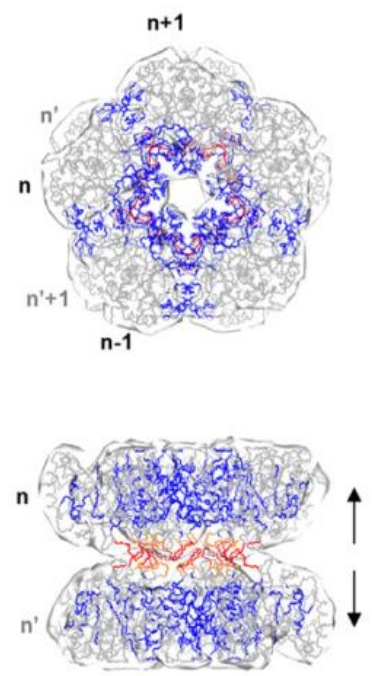

GSIII

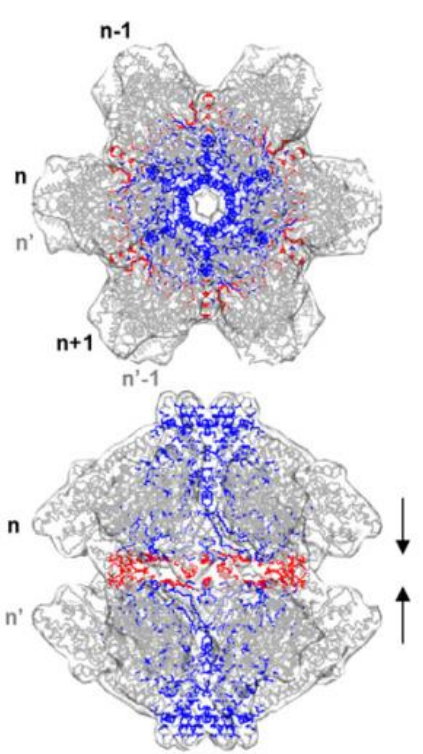

4. ábra: A GSI-III típusú izoenzimek alegységeinek kapcsolódási felszínei. [62]

GSI: Salmonella typhimurium, GSII: Zea mays, GSIII: Bacillus fragilis. Az elegységek kapcsolódását biztosító intermolekuláris kapcsolatok kékkel, az intramolekuláris kapcsolódások pirossal vannak feltüntetve. A kevéssé esszenciális intermolekuláris kapcsolódási felszínek narancs színnel jelöltek. 
A prokarióta enzim aktív centrumonként két bivalens kation kötőhellyel, egy $\mathrm{n} 1$ és egy $\mathrm{n} 2$ kötőhellyel rendelkezik. Az n1 kötőhely $\mathrm{Mg}^{2+}$ affinitása 50-szer nagyobb az n2 kötőhelyénél. Ennek megfelelően ezen kötőhelyek szubsztrátumaffinitása eltérő, az $\mathrm{n} 1$ kötőhely $\mathrm{Mg}^{2+}$-ra specifikusab, mint az n2, ahol a magnézium $\mathrm{Mn}^{2+}$-ra cserélhető. Az n1 kötőhelyen kötött fémionnak szerkezetstabilizáló hatása van, míg az n2-nek az adenililációs állapot befolyásolásában van szerepe [66]. A prokarióta GS-ok aktivitását befolyásolhatják egyes nitrogénanyagcsere-termékek, így a prokarióta nitrogén-anyagcsere a GS glutamin termelésén keresztül negatív feedback szabályozás alatt áll. Ezen termékek effektor hatásának megnyilvánulása az adenililációs állapottól függ. Az adenililálatlan enzim aktivitását nem gátolták az anyagcsere-termékek [67]. $\mathrm{A} \mathrm{Mn}^{2+}$ kötődése feltétele az adenililáció végbemenetelének, így a $\mathrm{Mn}^{2+}$ bekötődése determinálja a prokarióta GS működését a feedback szabályozás létrejöttét.

A magasabb rendü növények szerkezetéről kevesebb ismerettel rendelkezünk. $\mathrm{Az}$ eddigi vizsgálatok szerint a kukorica (Zea mays) GS felépítése hasonló a prokariótáknál leírtakhoz, de számos különbség is mutatkozik. Az aktív enzim 10 alegységes, a dekamert két 5-ös gyürü alakítja ki (5a ábra). Az aktív helyet a prokariótákhoz hasonlóan egy alegységpár alakítja ki, egy C- és N-terminális vég kapcsolódásával. Viszont a növényi GS-ok C-terminálisáról hiányzik az adenililációs hely, illetve nem rendelkeznek az alegységeket összekapcsoló, a fogadó alegységbe mélyen benyúló hélixszel, és a hélixet fogadó hely is hiányzik. Az alegységeket összetartó kölcsönhatások csak a monomerek külső felszínei között jönnek létre [63]. A Medicago truncatula szerkezetét is hasonlónak írták le [68]. A kukorica és Medicago GS-t leíró tanulmányok prokariótákban túltermelt GS fehérje szerkezetét jellemzik. A Medicago truncatula szerkezeti modellének alapjául a kukorica modell szolgált. A kukorica modell megalkotásakor viszont a már meglévő prokarióta modellekre támaszkodtak.

Oktamer GS izoenzimek szerkezetét vizsgálták borsó (Pisum sativum) és bab (Phaseolus vulgaris) növényekben is. A borsónövény kloroplasztiszban lokalizált izoenziméről elektronmikroszkópos felvételeket készítettek [69,70]. A vizsgálathoz kloroplasztiszból tisztított GS enzimfehérjét használtak fel. A felvételeken látható, hogy az enzim 8-alegységes (5b ábra). A tanulmányban bemutatott modell szerint az enzim két tetramer gyürű kapcsolódásával jön létre, ahol a monomerek a gyürü két oldaláról párt alkotva alakítják ki az aktív helyeket, ahogyan a prokarióták esetében is. 
A borsó modellel részben összhangban, részben ellentmondva született egy részletes tanulmány a bab GS szerkezetéről is. Az aktív helyet a borsó esetében is alegység dimerek alakítják ki, de a teljes komplex kialakulásának egységei az előzőekkel ellentétben nem a monomerek, hanem maguk a dimerek. A modell szerint a dimerek alkotnak középpontosan szimmetrikus gyürüket, melyek $90^{\circ}$-kal elforgatva helyezkednek el egymás alatt (5c ábra). Vagyis a katalitikus alegységek stabilitását elsősorban nem a gyürük, hanem a dimerek közötti kölcsönhatások szabják meg [71]. Prokariótákban bizonyították, hogy a gyürüröl dimerek válhatnak le [72], növények esetén pedig egy cikk említ aktív tetramereket, melyek 1\% $\beta$-merkaptoetanol hozzáadására jelennek meg levélből készült kivonatban [73]. Ezek az eredmények igazolják Llorca és munkatársainak fenti következtetéseit, a dimerek stabil kölcsönhatásáról.
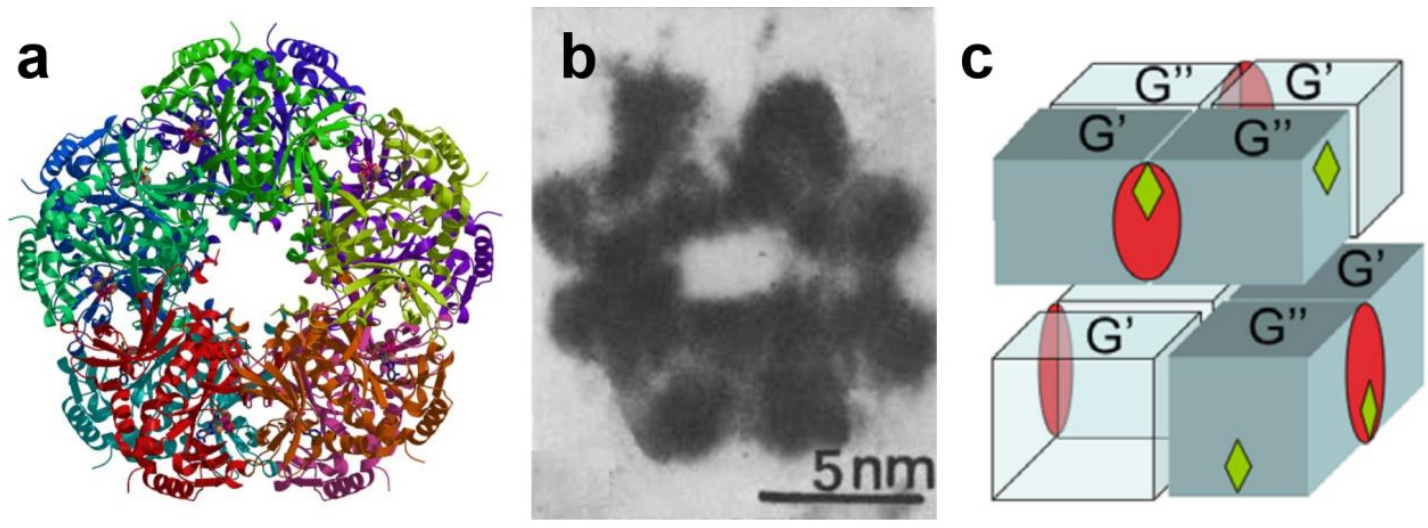

5. ábra: Növényi kloroplasztiszban lokalizált glutamin-szintetázok szerkezete.

(a): Kukorica (Zea mays L.) citoszolikus GS kalkulált szerkezete [63], (b): Borsó (Pisum sativum L.) kloroplasztisz GS elektronmikroszkópos felvétel [70], (c): Bab (Phaseolus vulgaris L.) kloroplasztisz GS szerkezeti modellje: a feltételezett aktív helyek pirossal, a feltételezett ATP kötőhelyek zöld rombusszal jelöltek [71].

A többféle modell rávilágít arra, hogy bár a katalitikus hely evolúciósan rendkívül konzervált, a holoenzim szerkezete, összeépülésének módja nem univerzális. Az irodalomban egymásnak ellentmondó eredmények vannak arról, hogy a GS gyürük szétválásuk után megtartják-e az aktivitásukat. Ugyanígy változó eredmények születtek azzal kapcsolatban is, hogy az egyes organizmusokból származó izomerek hány alegységes oligomerekre eshetnek szét valamely denaturáló ágens hatására. A Bacillus subtilis GS dodekamere urea hatására denaturálódik, ennek következtében a holoenzimről dimerenként hasadnak le az alegységek, melyek végül maguk is 


\section{Szakirodalmi áttekintés}

szétválnak [72]. A cukorrépa (Beta vulgaris) GS oktamere feltehetöleg olyan tetramerekké disszociál, melyek megfelelő ß-merkaptoetanol kezelés mellett megtarthatják aktivitásukat [73].

\subsubsection{A növényi GS jelátvitelben betöltött szerepe és ismert szabályozói}

A prokarióta GS-ok a fentebb bemutatott irodalmi adatok alapján tehát negatív feedback szabályozás alatt állnak, melyet az adenililáció és a $\mathrm{Mn}^{2+}$ ion kötődésének allosztérikus hatásai tesznek bonyolultabbá.

A GS kölcsönhatását 14-3-3 proteinnel Medicago truncatula növényben írták le. Ezt a kapcsolatot egy szerin oldallánc foszforilációja teszi lehetővé. Feltehetőleg, ennek az enzim aktivációjában, egy „ON/OFF” típusú szabályozásban lehet része [74]. A GS kölcsönhatását 14-3-3 fehérjékkel azóta sem mutatták ki más növényekben.

Lúdfü növényben felfedezték, hogy a GS2 az ACR11 uridilil-transzferáz szerü fehérjéhez közvetlenül kapcsolódik, melynek következtében megváltozik az aktivitása. Bár az aktivitás maximuma nem növekszik, az ACR11-el való kötődése a szubsztrátum telítés mechanizmusát változtathatja meg. Ezt az adott kísérletsorozatban a $\mathrm{K}_{\mathrm{m}}$ érték megváltozása mutatta [75]. Tehát az ACR11 a GS-on keresztül a GS-GOGAT-GDH rendszer érzékenységét változtatja meg, melyet a GS, a glutamin: 2-oxoglutarátamintotranszferáz (GOGAT) és a glutaminsav-dehidrogenáz (GDH) enzimek alkotnak. Ez az eredmény különösen annak fényében érdekes, hogy az ACR11-röl azt közölték, hogy a kloroplasztisz lokalizált ferredoxin kofaktort használó Fd-GOGAT poszttranszkripciós módosításáért lehet felelös [76].

A GS aktivitását az előzőek mellett közvetlenül befolyásolja a sejtek redox-állapota [77]. Valamint kimutatták, hogy a GS-t a nitrogén-monoxid által kiváltott tirozin-nitráció inaktiválhatja Medicago truncatula noduluszokban. A nitráció mértéke összhangban volt az effektív nitrogénfixálással, és úgy tủnik, a GS inaktivációja befolyásolja a NO által kiváltott antioxidáns választ. Ezt azzal magyarázzák, hogy a GS aktivitás csökkenésével a glutaminsav nagyobb arányban fordítható glutationszintézisre, amely az antioxidáns rendszer egyik meghatározó szereplője [78]. 


\subsubsection{A glutamin-szintetáz a növényi anyagcserében}

A nitrogén anyagcserében a GS minden eddig vizsgált fajban rendkívül fontos funkciót lát el. A GS izoformák minden élőlényben szinte azonos jelentőséggel bírnak az ammónia detoxifikációban és a glutaminsav-glutamin konverzió által az aminosavanyagcsere folyamatában. A GS izoenzimeknek az élővilágban betöltött funkciójában azonban vannak árnyalatnyi különbségek. Az organizmusok, mint eltérő élő rendszerek szintjén egyes folyamatokban sajátságosan, a GS nagyobb hangsúlyt kaphat. A GS a prokariótákban külön kiemelt szerephez jut a már említett feedback szabályozáson keresztül a nitrogén és aminosav-anyagcsere koordinálásában. Magasabb rendü állatokban, és emberekben pedig a GS megfelelő expressziója és működése elengedhetetlen az idegrendszer normál müködéséhez, a glutaminsav mint szignál molekula mennyiségének befolyásolásán keresztül.

A szakirodalomban széles körben elterjedt álláspont, hogy a növényekben a GS legfontosabb szerepe főként a felvett nitrogén asszimilációja és a növényi szervezetben képződő ammónia reasszimilációja. Ez két fontos sajátosság miatt lehetséges. Egyrészt az enzim nagy affinitással köti meg az ammóniumiont az aktív helyen, amit nagy hatékonysággal hasznosít. Másrészt a növényi nitrogénfelvétel során a glutamin-szintetáz az első a biokémiai konverziók sorát végrehajtó enzimfehérjék láncolatában, amely szénvázhoz képes kötni a szervetlen ammóniumiont.

Növényekben, lokalizációjuk alapján kétféle izoenzimet különböztetünk meg, a GS1-et a citoszolban és a GS2-t a kloroplasztiszban. Az izoenzimeket nukleáris gének kódolják, fajonként eltérő számban. Míg a citoszolikus formákat lúdfüben 5 [79], tritikáléban 4 [80], rizsben 3 [81] gén kódolja, addig az említett fajokban a kloroplasztiszban lokalizált formáért egyetlen gén felelős.

A búza elsődleges nitrogénasszimilációjában a citoszolikus GS1 jelentősége kiemelkedő a talajoldatból felvett ammóniumion megkötésével. Emellett a GS2 az ammóniumot termelő nitrit-reduktázzal együtt lokalizálódik a kloroplasztiszban, közvetlenül hasznosítva a nitrát redukciójából származó asszimilálható nitrogént.

Habár mindkét izoforma rendkívül fontos a nitrogén asszimilációjához, de egyéni feladatkörük más fiziológiás állapotokban teljesedik ki. Ammóniumion nem csak az ammóniumion felvételből és a nitrit redukcióból származhat, katabolikus, deaminációs reakciók termékeként, a fotorespirációs ciklusban is jelentős mennyiségü ammónium szabadul fel. 
A fotorespiráció, egy fotoautotróf $\mathrm{CO}_{2}$ fixáció a szénanyagcsere egy igen jelentős útvonala, amely a Rubisco oxigenáz aktivitásából ered. Ebben az útvonalban a Rubisco terméke egy glicerinsav-3-foszfát (3PG) mellett egy glikolsav-2-foszfát (2PG) molekula. Két molekula 2PG-ból a folyamat végén egy $\mathrm{CO}_{2}$ és egy $3 \mathrm{PG}$ molekula képződik, melyek rendre bekapcsolódhatnak a $\mathrm{CO}_{2}$-fixációba, valamint Calvin-Benson ciklusba [82]. A 2PG a kloroplasztiszban glikoláttá alakul, amelynek peroxiszómális konverziója során glicin képződik. A glicint a mitokondriális glicin-dekarboxiláz multienzimkomplex alakítja át szerinné [83]. A fotorespirációs ciklusban ennél a lépésnél rendkívül nagy mennyiségü ammónia szabadul fel. A C3-as növényekben a fotorespirációs ciklusban képződő ammónia a nitrátredukcióból származó mennyiségétől akár nagyságrendekkel is nagyobb lehet [84]. Bizonyítást nyert, hogy a növények levelében megtalálható izoenzimek közül a GS2 izoforma kulcsfontosságú ennek a fotorespirációs ammóniumnak a megkötésében [85]. Amennyiben a GS2 aktivitás nem követi kielégítően az ammónium képződését, a növény ammóniakibocsátása megnövekedhet [86]. Az emittált ammóniát pedig nettó energiaveszteségként is elkönyvelhetjük, tekintve a nitrogén asszimiláció ATP költségét. Ebböl következik, hogy a növényeknek a befektetett energiával felvett nitrogént meg is kell tartaniuk, és hiába rendelkezik a növény más aminációs reakciókat végrehajtó enzimekkel GS2 az, amely ezt a feladatot képes ellátni.

Mindemellett a GS1 szerepe sem elenyésző. Az öregedő növényi részekben proteolitikus lebontó folyamatok indulnak be. Ezen folyamatok során a növényi sejtekben extra ammónium jelenik meg. Az öregedéssel a kloroplasztisz lokalizált GS2 fehérje mennyisége lecsökken, míg a citoszolikus GS1 izoforma mennyisége növekszik. A szeneszcencia során tehát az ammóniaveszteség minimalizálódik a GS1 növekvő aktivitásának köszönhetően, egyúttal a GS1 a nitrogént transzlokálhatóvá teszi a floémen keresztül [87]. Sőt, a floém jól szabályozott aktív feltöltődése a kísérősejteken keresztül megy végbe, ahol csak a citoszolikus izoforma van jelen [88]. Hasonlóan, a stressz indukálta korai öregedés folyamán is csökken a GS2 mennyisége, míg a GS1-é ezzel párhuzamosan növekszik [12]. Tehát a kloroplasztiszt érintő szeneszcencia vagy stressz indukálta degradáció és katabolikus folyamatok a kloroplasztisz lokalizált GS2-t is érintik, melynek következményeként megnő a citoszolikus GS1 biokémiai és élettani jelentősége.

A glutamin-szintetáz a GS-GOGAT-GDH útvonal eleme (6. ábra). A GOGAT a glutamint metabolizálja a kloroplasztiszokban. Egy molekula a-ketoglutársavval és 
glutaminnal a GOGAT 2 molekula glutaminsavat hoz létre. A glutaminsavat GDH hasznosítja, amely ammóniumot és 2-oxoglutársavat képez [89]. A GDH in vitro a reverz reakciót is katalizálhatja, ami miatt olykor máig tudományos vita tárgyát képezi a GDH ammónia asszimilációban betöltött pontos szerepe [90]. A nitrogénraktárak katabolizmusa esetén megfigyelték a GDH aktivitásának növekedését. Ez speciális nevelési körülmények között is előfordul, mikor a nitrogén rendkívül nagy feleslegben elérhető a növény számára [91]. Ez arra enged következtetni, hogy a GDH legfeljebb speciális körülmények között jut komolyabb szerephez a másodlagos nitrogén asszimilációban, és elsődleges feladata a 2-oxoglutársav termelése, mely a trikarbonsav ciklusban hasznosul [2]. Emellett a megállapítás mellett szól az az érv is, hogy a GDH ammónia affinitása jóval a glutamin-szintetázé alatt marad [91]. Emellett az aszparagin-szintetáz is használ ammóniumiont, de jóval kisebb hatékonysággal, mint a GS.

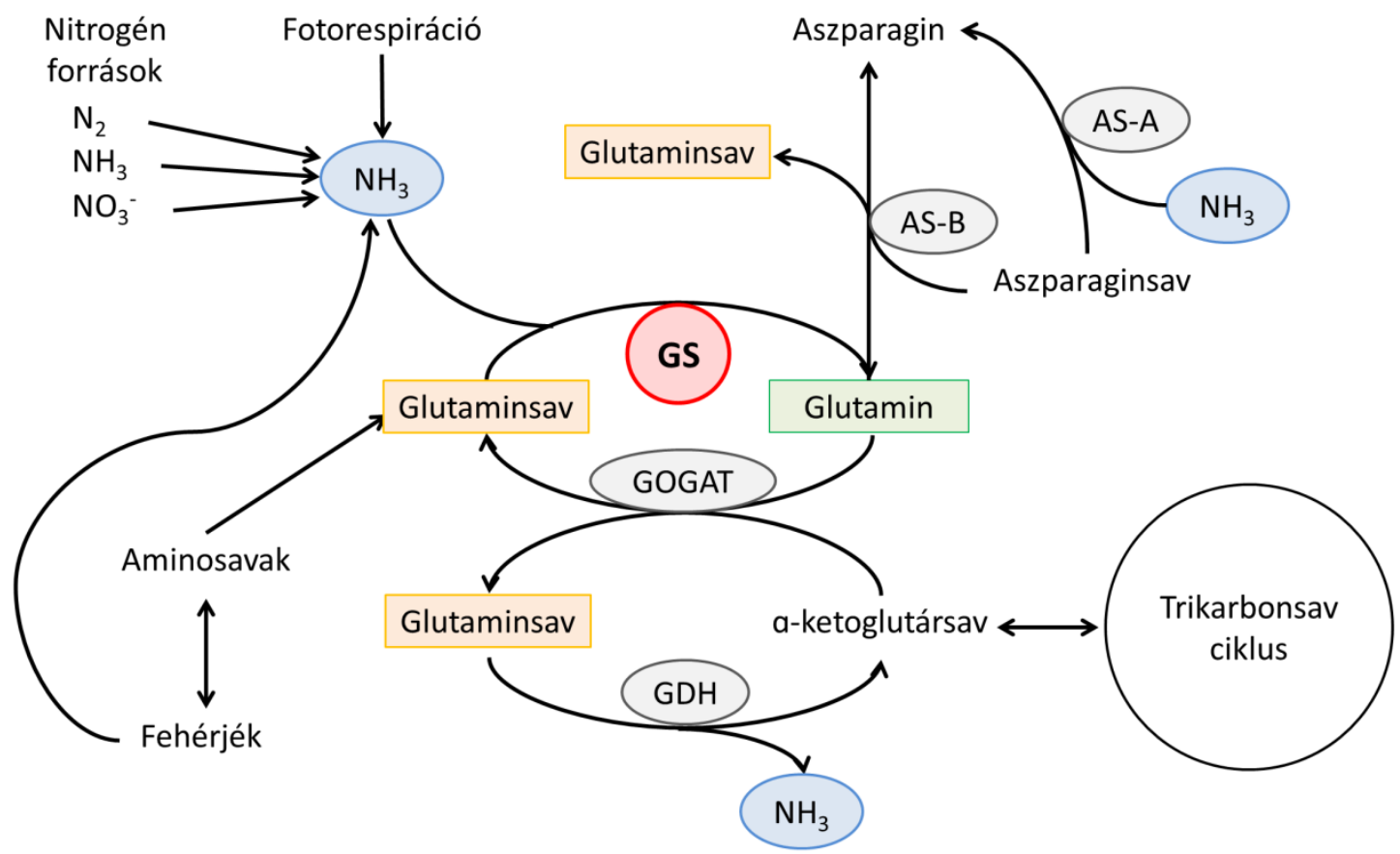

\section{6. ábra: A glutamin-szintetáz a növényi anyagcserében.}

A glutamin-szintetáz (GS) központi szerepe glutamin és a glutamát legjelentősebb forrásai és felhasználása, a szén- és nitrogén-anyagcsere kapcsolata. AS-A: aszparagin-szintetáz; AS-B: aszparagin szintáz; GDH: glutamát-dehidrogenáz; GOGAT: glutamin-2-oxoglutarátaminotranszferáz. (Miflin és Habash munkája alapján [2]) 
A glutamin-szintetáz nem az egyedüli enzim, amely a glutamin, glutamát és ammónium mennyiségét kontrollálja, mégis ennek az enzimnek van a legjelentősebb biokémiai szerepe, mind az elsődleges, mind a másodlagos nitrogén asszimilációban. A GS izoenzimek nélkülözhetetlen szerepét több mutáns analízis is igazolta. Árpa GS2 mutánsok nem képesek forotrespirációs körülmények közt növekedni, illetve ilyen esetben nő a növények ammóniakibocsátása [92]. Rizsben a GS2 koszuppressziója a növényt képtelenné tette az elégséges nitrogénmobilizációra, ami a szén/nitrogén arány eltolódását okozta. Emellett a cukrok és a szerves savak felhalmozódását figyelték meg [93]. GS1 túltermelő rizs mutánsokban azt tapasztalták, hogy a növényi sejtekben lecsökkent a szervetlen nitrogén formák mennyisége. A GS1;2-túltermelő vonalak stressz ellenállósága csökkent só, szárazság és hideg stressz esetén. A stressztürés romlását a GS1;1-túltermelő növények esetében nem tapasztalták, sőt egyes fejlődési fázisokban ezeknek a vonalaknak nőtt a foszfinotricin (GS gátlószer) ellenállósága [94].

\subsubsection{A glutamin és glutaminsav szerepe a növényi anyagcserében}

A GS-GOGAT-GDH ciklus tehát közvetlenül befolyásolja a glutamin és glutaminsav mennyiségét. A glutamin és glutaminsav a kloroplasztiszból karboxilát-transzportereken keresztül jut ki. A glutaminsav a glutamát-malát (DiT2) antiporter segítségével jut ki a kloroplasztiszból, a malátot pedig egy malát-2-oxoglutársav (DiT1) antiporter juttatja vissza a kloroplasztiszba. Ezek a transzporterek nem teljes mértékben specifikusak, a glutaminsav helyett glutamin, de más vegyületek is transzportálódhatnak elenyésző mértékben $[95,96]$. A DiT1 és DiT2 mellett régóta feltételezik egy glutamin-glutaminsav antiporter létezését [90,97], de még nem sikerült izolálni. Fenyőben találtak arra utaló bizonyítékokat, hogy létezhet ilyen transzporter [98], ahol is úgy tünik, hogy a citoszolikus GS1 az uralkodó izoforma [99].

Amennyiben búzában csak az eddig ténylegesen karakterizált DiT1és Dit2 transzportrendszerek dolgoznak, az esetben a kloroplasztiszból nagy valószínűséggel a glutaminsav jut ki nagyobb mennyiségben. Tehát a GOGAT-nak nem csak az a szerepe, hogy a GDH-t és a GS-t ellássa szubsztrátumtal, de egyben glutaminsav formájában teszi transzportálhatóvá az asszimilált nitrogént. 
Az asszimilált nitrogén a floém elemekben szállítódik a felhasználás helye felé. A búza floémnedv teljes aminosav tartalmának legnagyobb részét a glutaminsav teszi ki, de jelentős még az aszparaginsav tartalma is [15,100,101]. Lehetséges, hogy az aszparaginsav egy oxaloacetátból és egy glutaminsav a-amino csoportjából jön létre az aszpartát-aminotranszferáz (EC 2.6.1.1) közremüködésével [102]. Az aszparaginsav felhasználása az aszparagin-szintáz által valósul meg. Az enzim a már glutamin formájában asszimilált ammónia felhasználásával képes létrehozni aszparaginsavat és glutaminsavat.

$\mathrm{Az}$ is ismert, hogy a glutamin és glutaminsav mennyisége, aránya megváltozhat az egyes szövetekben eltérő nitrogén-ellátottság alatt. Valószínüleg ennek szerepe lehet a növények hosszútávú jelátviteli folyamataiban [15].

Magasabbrendủ állatokban a glutaminsav nemcsak metabolikus, de jelátviteli, neurológiai szempontból is egy igen fontos molekula. Ezért a glutamát-receptort már rég ismerik és tanulmányozzák mind állati, mind humán vonatkozásban. Az állati ionotróp glutamát-receptorokkal homológ szekvenciákat az ezredforduló környékén írták le részletesen lúdfüben [103]. Ismert volt, hogy az aminosavak hatással vannak a növények növekedésére és fejlődésére. A glutaminon kívül minden más esszenciális aminosav gátolta a gyökérnövekedést. Úgy gondolták, a gátlás a biokémiai egyensúly felbomlásának eredménye. A jelenséget akkor általános aminosav gátlásnak nevezték el [104,105], melyet növekedési és farmakológiai tesztekkel később részletesen tanulmányoztak. [106,107]. Végül a növényi glutamát receptor-szerü fehérjéket úgy azonosították, mint aminosav-érzékelő ioncsatornákat [108]. Glutamát receptor homológokat a plazma- és kloroplasztisz membránban is azonosítottak [109], emellett a mitokondriális membránban is találtak bizonyítékot a glutamát receptorok jelenlétére lúdfüben [110].

A növényi glutamát-receptor tehát az ezredforduló után került igazán a figyelem középpontjába. Szignalizációs hálózatokban, élettani folyamatokban betöltött pontos szerepe pedig jelenleg is felderítés alatt áll [111,112]. Feltételezik, hogy ezeknek szerepe lehet a nitrogén, vagy aminosav ellátottság érzékelésében [113].

A glutamin és a glutaminsav tehát egyrészt fontos biokémiai reakciók kiindulási anyagai. Általuk a GS-GOGAT-GDH cikluson át a 2-oxoglutársav képződésén keresztül kapcsolatba kerül az aminosav-anyagcsere a trikarbonsav ciklussal. A glutaminsav ráadásul a klorofill bioszintézis alapja is [90]. De mindezek mellett a glutamátreceptor-szerü fehérjék felfedezésének köszönhetően a glutaminsav ma már 
nem csak egy metabolikus intermedier a nitrogén anyagcserében, hanem a növényi jelátviteli hálózatok egy újabb jelmolekulája [114], melynek metabolizmusát érdemes vizsgálni.

\subsubsection{A búza glutamin-szintetázai}

A GS izoformákat az igencsak összetett és méretes allohexaploid búza genomja több helyen kódolja. Szekvencia homológia alapján 10 szekvencia kódolja a GS izoenzimeket, melyek 4 alcsaládba rendezhetők a következök szerint: GS2 (a, b és c), GS1 (a, b és c), GSr (1 és 2) és GSe (1 és 2). Az átíródó fehérjék rendre 427, 356, 354 és 362 aminosavból állnak. Csak a GS2 rendelkezik a kloroplasztiszba való bejutáshoz szükséges tranzit peptid szekvenciával. Ez alapján a GS1, GSr, és GSe izoformákat citoszolikus izoformákként tartjuk számon. A publikált szekvencia alapján a GS2 izoenzimek rendkívül konzerváltak [88] A 427 aminosavból álló fehérjék csak néhány aminosavban térnek el. A GS2b a GS2c-től 3, GS2a a GS2c-től 5, míg a GS2a a GS2b-től 8 helyen tér el. Ezen különbségek többsége neutrális, nem poláros aminosav cseréje neutrális, poláros aminosavra. AGS2b és GS2c 273. bázikus, arginin aminosava helyett a GS2a-ban glicin szerepel, és a GS2b és GS2c-hez képest a GS2a a 362.-es aminosav pozícióban egy $-\mathrm{SH}$ csoportot nyer egy glicin $\rightarrow$ cisztein cserével. Arabidopsisban a citoszolikus GS izoformát kódoló szekvenciákban írtak le olyan kitüntetett pozíciókat, melyek közvetlenül befolyásolják a szubsztrátum affinitást [115]. A homológ búza GS2 szekvenciák közötti eltérések viszont nem érintik ezeket a kitüntetett pozíciókat. Ezek a cserék a GS fehérje monomerek szerkezetét és müködését feltehetőleg lényegesen nem befolyásolják.

\subsection{A mangán és alumínium}

A mangán a növények számára fontos mikroelem. Kiemelt szerepet tölt be a redox homeosztázisban a mangánt-kötő szuperoxid-dizmutáz kofaktoraként, valamint a kettes fotokémiai rendszer vízbontó komplexének részeként, de a mangán emellett más biológiai folyamatokat is katalizálhat például a benzoil-koenzim A-reduktáz (EC 1.3.7.8) vagy az oxalát-oxidáz (EC 1.2.3.4) enzimek kofaktoraként. A mangán 
a talajban számos formában van jelen (7. ábra). A környezetben jelenlévő mangán speciációk azonosítása régóta folyik, és az elválasztási, analitikai módszerek fejlődésével egyre több forma azonosítására nyílik lehetőség [116]. A növények számára felvehető mangán mennyisége változhat a talaj összetételétől, kémhatásától, redox állapotától függően. Ezeket az állapotokat nagymértékben befolyásolják a talaj vízviszonyai és a talaj mikrobiális közössége, a mikrobiális közösség összetételét érintő változások [117]. A pH csökkenésével a talajoldatban megnő a mangán mennyisége, így a $\mathrm{Mn}^{2+}$ akár a növények számára toxikus mennyiségben is feldúsulhat. Emiatt a nem megfelelő agrotechnikai eljárásoknak kitett, vagy a nem megfelelő vízellátottságú, időszakosan elárasztott vagy kimosott talajokon nevelt növények életképessége csökken. A szervetlen nitrogén-trágyázás szintén közvetve emelheti a talajoldatban a mangán mennyiségét, amelynek nemcsak mezőgazdasági, de ökológiai következményei is lehetnek [1]. A talajok kiegyensúlyozatlan vízháztartása és savanyodása egyes hazai mezőgazdasági hasznosítás alatt lévő területekre is jellemző. Magyarország terület használati és talajviszonyai a II. mellékletben megtalálható térképeken tekinthetők meg.

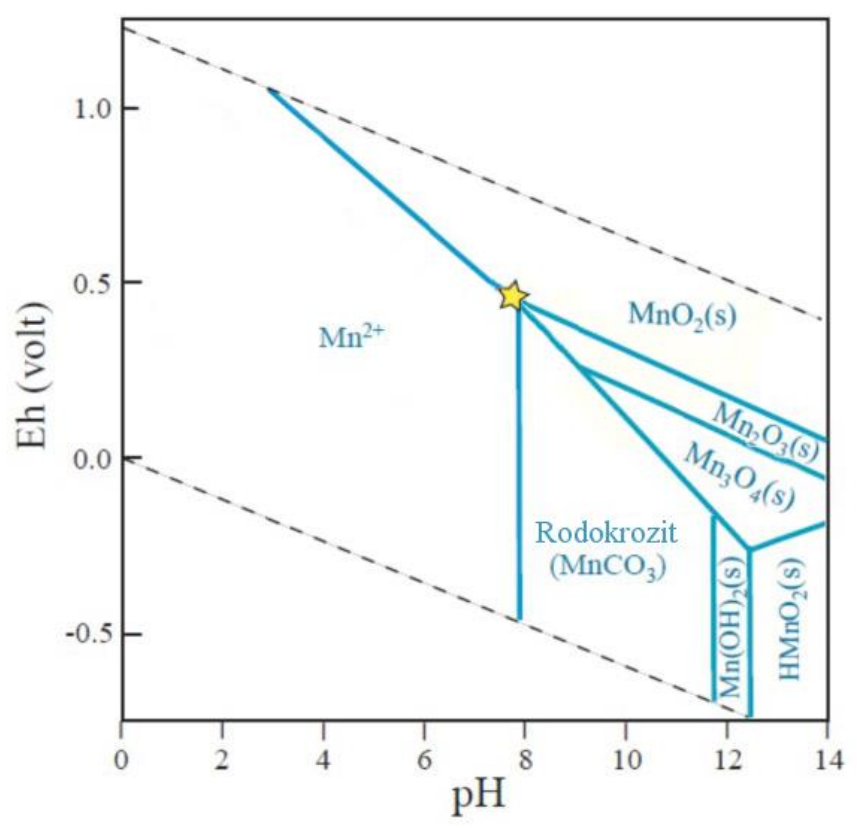

7. ábra: A mangán EH-pH diagramja [118].

A mangán és króm vegyületek mennyiségének, oxidációs állapotának változásai a talajoldatban. Eh a környezet redukáló képességét, a pH a talaj kémhatását, (s) a szilárd formákat jelöli.

A savanyú talajok jelentős része esetén tapasztalható az alumínium- és mangánionok feldúsulása. Az alumínium számos formában jelen van a talajban, melyek 
közül egyes szervetlen formákról $\left(\mathrm{Al}^{3+}, \mathrm{AlOH}^{2+}, \mathrm{Al}(\mathrm{OH})_{2}{ }^{+}, \mathrm{AlO}_{4} \mathrm{Al}_{12}(\mathrm{OH})_{24}(\mathrm{H} 2 \mathrm{O})_{24}{ }^{7+}\right)$ már bebizonyosodott, hogy toxikus hatással lehetnek a növényekre, gátolva azok fejlődését, növekedését [119]. Ez a hatás azonban koncentrációfüggő, sőt, bizonyos tartományban elősegítheti a gyökérzóna biomasszájának növekedését [120]. Ezen felül a savanyú talajokhoz adaptálódott fajok esetében az alumínium kifejezetten elönyös hatással lehet a gyökérfejlődésre vagy akár a teljes biomassza termelésre [121,122].

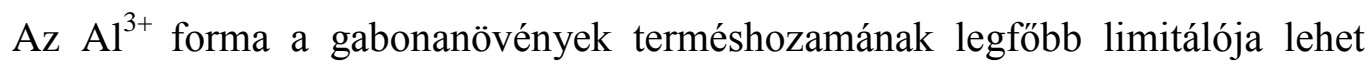
savas talajokon. A toxikus mennyiségben jelenlévő $\mathrm{Al}^{3+}$ a sejtekben oxidatív robbanást okoz, melyet az alumínium-stressz következményeként írtak le [123]. Az alumínium stressz tolerancia kialakulásában viszont jelentős szereppel bír az enzimatikus antioxidáns rendszer tagjai közül a kataláz és a glutation-S-transzferáz megnövekedett aktivitása [124].

$\mathrm{Az}$ alumínium-stressz közvetlen hatásának tekinthető a membrántranszport-folyamatok megváltozása. Zsoldos és munkatársai fedezték fel $\mathrm{az} \mathrm{Al}^{3+}$ okozta $\mathrm{K}^{+}$-transzport változásokat az általunk is vizsgált Jubilejnaja 50 búzafajtában [125]. Később azt is sikerült kimuttatni, hogy a Jubilejnaja 50 GS aktivitását az $\mathrm{Al}^{3+}$ jelenléte közvetlenül befolyásolta in vitro kísérletekben. $\mathrm{Az} \mathrm{Al}^{3+}$ közvetlenül kötődik az enzimhez, és megemeli annak aktivitását [126]. Tehát feltételezhető, hogy az $\mathrm{Al}^{3+}$ a fehérjékhez kapcsolódva megváltoztatja a sejtek metbolikus és jelátviteli útvonalainak működését.

Alumínium-tolerancával kapcsolatos gént márt többet is sikeresen azonosítottak. Rizsben találták meg az ART1 cink-ujj transzkripciós faktort, mely 31 gén müködését szabályozza [127]. Ezek közül az egyik az Nrat1 (Nramp alumínium transzporter 1), egy plazmamembrán lokalizált $\mathrm{Al}^{3+}$-transzporter, amely a természetes rezisztencia-asszociált makrofág fehérje család, az Nramp tagja [128]. Lúdfüben az $\mathrm{Al}^{3+}$-indukálható AtALMT1 malát-transzporter esszenciálisnak bizonyult az alumíniumtolerancia kialakításában [129]. Mindemellett az aquaporinok egy alcsaládjának tagja, a NIP1;2 plazmamembrán fehérje is szerepet játszik a stressztolerancia kialakulásában. A NIP1;2 az Al-malát sejtből való kizárásáért felelős [130].

Míg az alumínium okozta toxikus tünetek elsősorban gyökérben, addig a mangán által kiváltott tünetek inkább a hajtásban nyilvánulnak meg [131]. A tünetek és fiziológiai hatások mellett már ismeretes, hogy a mangán toxikus körülmények között a levélben halmozódik fel nagy mennyiségben [132]. 
A mangánt a növények Mn(II) oxidációs állapotban képesek felvenni, szállítani, akkumulálni. Toxikus mennyiségü $\mathrm{Mn}^{2+}$ jelenlétében lejátszódó fiziológiai változások a redox homeosztázis érintettségét jelzik. Ennek okán kialakult egy olyan álláspont, hogy a növények mangán-stressz toleranciájának kulcsa a mangán által indukált oxidatív stressz kivédése lehet [131]. Más megközelítésben viszont a mangán-transzport megfelelő irányításával is lehetséges a stressz tolerancia növelése.

A $\mathrm{Mn}^{2+}$ szállítása a növényen belül többféle membrántranszporteren keresztül valósulhat meg. Leírtak olyan transzportereket, melyek nem specifikusan a mangán transzlokációját valósítják meg, de affinitásuk miatt lehetővé teszik $\mathrm{Mn}^{2+}$ ionok transzmembrán mozgását. Például a ZIP (ZRRT/IRT-Like Protein) transzportercsalád egyik tagja, az IRT1 vas-transzporter képes $\mathrm{Fe}^{2+}$ mellett más ionok, $\mathrm{Mn}^{2+}$ és $\mathrm{Cd}^{2+}$ transzlokációját végrehajtani [133]. Élesztővel végzett komplementációs tesztekben bebizonyosodott, hogy a VIT1 (ㅌacuolar Iron Transporter) fehérje szerepet játszik a vas- és mangántranszportban, melynek vakuoláris lokalizációját lúdfüben kétséget kizáróan azonosították [134]. Specifikus mangán-transzporterként eddig az NRAMP2-t azonosították lúdfüben. Az NRAMP2 a transz-Golgi hálózat markereivel kolokalizálódik, mutációja alacsony plasztidikus és vakuoláris mangántartalommal jár együtt [135].

A mangán felvételét és szállítását tehát a különböző membránrendszereken számos transzporter szabályozza, melyek közül még számos fehérje pontos azonosításra vár [136]. Az azonosítást a kation transzportercsaládok sokfélesége és aspecifikussága is bonyolítja. Az viszont bizonyos, hogy a mangán nem csak eljut az egyes intracelluláris kompartmentekbe, de toxikus mennyiségü mangán jelenléte a talajoldatban a redox homeosztázis felborulásához, a fehérjeműködés, és az anyagcsere zavarához vezet. 


\section{Célkitüzések}

A glutamin-szintetáz a C3-as fotoszintézisű növények legfontosabb nitrogénanyagcsere enzime. A GS2 intracelluláris lokalizációjából és funkciójából adódóan is az egyik legfontosabb enzim a búza növények anyagcseréjében. A levél öregedése során, amíg a kloroplasztisz degradálódása nem okozza annak funkcióvesztését, a glutamin-szintetáz kloroplasztisz lokalizált GS2 izoformája esszenciális szerepet tölt be az ammóniumionok szénvázhoz kötésében, ezáltal közvetve a szerveskötött nitrogén floém elemeken keresztüli, a felhasználás helyéig történő irányított szállításában.

$\mathrm{Az}$ anyagcsereutakban az allosztérikusan szabályozott enzimek a különböző biokémiai termékek képződési folyamatainak kapcsolói és finomhangolói. A glutamin-szintetáz kloroplasztisz lokalizált izoformájának kiemelt jelentősége és megfelelő lokalizációja alapján feltételeztük, hogy a búza GS2 olyan allosztérikus szabályozással rendelkezik, amely szubsztrátumszinten képes a biokémiai egyensúly fenntartására a szén- és nitrogén-anyagcsere között.

A vizsgálatok során a következő problémákra, kérdésekre kerestünk megoldást:

1) Hogyan jellemezhetők a natív konformációjú GS izoenzimek?

a. Homogén alegységszerkezettel rendelkeznek-e az egyes izoformák?

b. Gélelektroforetikus módszerekkel kimutatható-e a GS2 izoformához olyan vegyület kapcsolódása, mely megváltoztatja az enzim aktivitását?

2) Rendelkezik-e a GS2 enzim valamilyen allosztérikus szabályozással?

a. Befolyásolja-e a GS2 aktivitást a reakció során képződő természetes, illetve mesterséges termék?

b. Hogyan változik a GS2 aktivitása eltérő szubsztrátumellátottság esetén nyers és tisztított kivonatban?

c. Van-e a GS2-nek allosztérikus regulátor szubsztrátuma?

d. Az általam alkalmazott aktivitás mérések során jelen van-e olyan effektor, amely befolyásolhatja kinetikai mérések eredményeit?

3) Milyen egyszerüsített modellel illetve matematikai formulával karakterizálható a GS2 müködése? 
4) Milyen hatással van egyes fémionok jelenléte a GS által katalizált reakcióra?

a. Hogyan telítődik az enzim magnézium kötőhelye? Mennyi az a telítési $\mathrm{Mg}^{2+}$ koncentráció, ami mellett vizsgálhatjuk a $\mathrm{Mn}^{2+}$ és $\mathrm{Al}^{3+}$ hatását?

b. Milyen hatással van az $\mathrm{Al}^{3+}$ és a $\mathrm{Mn}^{2}$ a glutaminsav-felhasználás dinamikájára, milyen módon befolyásolhatják az aktivitást? 


\section{Anyagok és módszerek}

\subsection{Növényi anyag}

Kísérleteinkhez Triticum aestivum L. cv. Jubilejnaja 50 búzafajtát használtunk. A fajtát 1970-ben jegyezték be. A középérésü, malmi minőségü termést adó fajta a magyar mezőgazdaság sokáig népszerü eleme volt, abiotikus stresszorokkal szemben jó adaptív képességü, a biotikus stresszoroknak kevéssé elenálló.

A magokat 2 óra csapvizes ázatás után nedves szürőpapíron Petri-csészében csíráztató szekrénybe helyeztem, ahol $24{ }^{\circ} \mathrm{C}$-on tartottuk 24 órán át. A csírázásnak indult magok szitára helyezve $5 \cdot 10^{-4} \mathrm{M} \mathrm{CaSO}_{4}$ oldatra kerültek, 1 napra üveg fedővel leborítva, védve az apró csíranövényeket a kiszáradástól. Az így elhelyezett növények gyököcskéje sértetlen marad, biztosítva a gyökér zavartalan fejlődését. Az áztatástól számított harmadik napon a $\mathrm{CaSO}_{4}$ oldatot módosított Hoagland tápoldatra cseréltük [137], melynek összetételét az 1. táblázat tartalmazza. A csíranövények oldatra helyezésüktől $24{ }^{\circ} \mathrm{C}$ hőmérsékleten, $200 \mu \mathrm{mol} \mathrm{m} \mathrm{m}^{-2} \mathrm{~s}^{-1}$ fotonfluxus sürüség mellett, 12/12 órás nappali/éjszakai periódussal növekedtek egy héten át.

\begin{tabular}{|l|c|}
\hline \multicolumn{2}{|c|}{$\begin{array}{c}\text { Makroelemek } \\
(\mathrm{mM})\end{array}$} \\
\hline $\mathrm{Ca}\left(\mathrm{NO}_{3}\right)_{2}$ & 2 \\
\hline $\mathrm{MgSO}_{4}$ & 1 \\
\hline $\mathrm{KH}_{2} \mathrm{PO}_{4}$ & 0,5 \\
\hline $\mathrm{Na}_{2} \mathrm{HPO}_{4}$ & 0,5 \\
\hline $\mathrm{KCl}$ & 0,5 \\
\hline
\end{tabular}

\begin{tabular}{|l|c|}
\hline \multicolumn{2}{|c|}{$\begin{array}{c}\text { Mikroelemek } \\
(\mu \mathrm{M})\end{array}$} \\
\hline Fe-EDTA & 10 \\
\hline $\mathrm{H}_{3} \mathrm{BO}_{3}$ & 10 \\
\hline $\mathrm{MnSO}_{4}$ & 1 \\
\hline $\mathrm{ZnSO}_{4}$ & 0,5 \\
\hline $\mathrm{Na}_{2} \mathrm{SiO}_{3}$ & 0,5 \\
\hline$\left(\mathrm{NH}_{4}\right)_{6} \mathrm{Mo}_{7} \mathrm{O}_{24}$ & 0,1 \\
\hline $\mathrm{CoCl}_{2}$ & 0,1 \\
\hline
\end{tabular}

1. táblázat: A módosított Hoagland tápoldat összetétele.

A tápoldatot a csíranövények nevelésének 3. napjától alkalmaztuk.

A növényeket 1 hetesen használtuk fel kétleveles állapotig, mely állapotban a fiatalabb, második levél még nem terült ki teljes mértékben. A kísérletekhez csak az első, tehát idősebb, kifejlett levelek levéllemezének középső régiója került felhasználásra. A levélcsúcs és a levélalap felőli körülbelül 1,5 cm-t eltávolítottuk, így 


\section{Anyagok és módszerek}

csak a közel hasonló fejlődési stádiumban lévő sejtekből álló növényi szövetből származó enzimfehérjék kerülhettek később a fehérjekivonatba.

A növények pontos fejlettségét és a neveléshez használt rendszert a 8 . ábra mutatja. A tápoldatot tartalmazó főzőpohár tetején a magok egy leemelhető szitán helyezkednek el. Amíg a csíranövények a szita tetejének magasságát el nem érik növekedésük során, óraüveggel lefedjük, óvva azokat a kiszáradástól. A növények növekedésével az ábrán látható támasztékot alkalmazzuk. A támaszték védi a növényeket a megdöléstöl a tápoldat csere alatt. A nevelés ideje alatt a tápoldatot tartalmazó poharat fekete papírral vesszük körbe. Ezzel megelőzzük, de legalábbis csökkentjük annak a lehetőségét, hogy a tápoldatban esetlegesen nem kívánt alga fajok szaporodjanak fel. Amíg a csíranövények nem rendelkeznek jelentősebb gyökérzettel, a tápoldatot a szitáig érdemes tölteni. A gyökerek fejlődésével a folyadékoszlopot érdemes alacsonyabban tartani, hogy lehetőség szerint elkerüljük a penészgombák megjelenését.

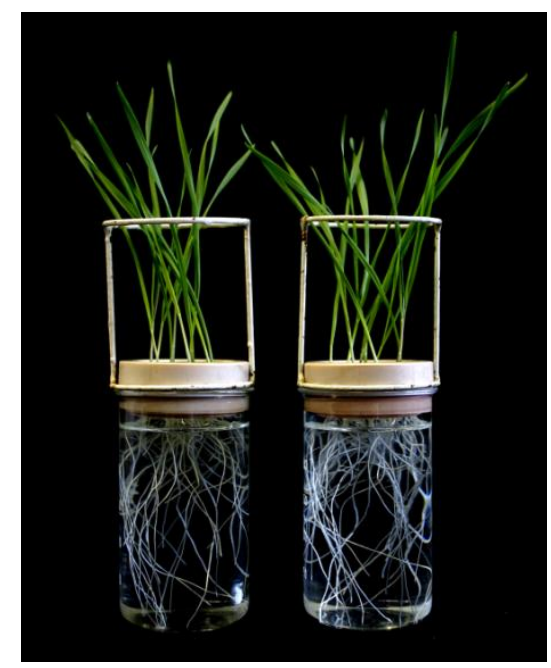

\section{8. ábra: Egy hetes búzanövények.}

A kísérletekhez használt növények, kétleveles stádiumban. A kép elsősorban a növények állapotát illusztrálja, a nevelés során a főzőpoharakat befedjük.

\subsection{Enzimkivonat készítése}

A gondosan begyüjtött növényi anyagot $1: 3$ (g növény : ml kivonó puffer) arányban hozzáadott kivonó pufferrel dörzsmozsárban homogenizáltuk. A feltárási folyamatot kevés kvarchomok hozzáadásával segítettük elő. A kivonatot 


\section{Anyagok és módszerek}

Eppendorf-csövekben centrifugáltuk 10 percig, $4{ }^{\circ} \mathrm{C}$-on, $13100 \mathrm{~g}$ erővel, a felülúszót összegyüjtöttük. Az extrakciós puffer összetétele: $200 \mathrm{mM}$ TRIZMA base, $3 \mathrm{mM}$ ditiotreitol, $1 \mathrm{mM}$ redukált glutation, $10 \%$ glicerol, $0,1 \%$ proteáz gátló (Cat.No.: P9599, Sigma-Aldrich, St. Louis, Missouri, Amerikai Egyesült Államok). A kísérletekhez mindig friss növényi anyagot használtunk, felhasználás pillanatáig az extraktumot jégen tároltuk. A későbbiekben a kivonatot a GS aktivitásának méréséhez, fehérjetartalom meghatározásához, a GS izoenzimek gélelektroforetikus elválasztásához használtuk fel.

A fehérjekoncentrációt Bradford [138] módszere alapján határoztuk meg. Ezzel a módszerrel spektrofotometriásan mérhető az oldott fehérjék koncentrációja. A méréshez $900 \mu \mathrm{l}$ desztillált víz, $100 \mu \mathrm{l}$ Bradford reagens és $5 \mu 1$ növényi minta keverékét használtuk, melyet 595 nm-en fotometráltunk Uvikon XL (Secomam, Alès, Franciaország) típusú készülékkel. A referenciaoldat $900 \mu$ ldesztillált vizet és $100 \mu 1$ Bradford reagenst tartalmazott.

\subsection{Poliakrilamid gélelektroforézis}

A poliakrilamid gélelektroforézis (PAGE) a fehérjeelválasztás egy igen hatékony módszere, mely elektromos térbe helyezett térhálós szerkezetű gélben lehetővé teszi oldható fehérjék szeparálását. A módszer céljainknak megfelelő változtatásokat alkalmazva számos elválasztási eljárást rejt magában. Az elválasztás hatékonysága igényeink szerint befolyásolható a futtatás időbeli és térbeli hosszával, a futtató pufferek összetételének, valamint a gél háromdimenziós szerkezetének módosításával.

Vizsgálatainkhoz vertikális elrendezésű Mini-Proten II Dual Slab (Bio-Rad, Hercules, California, Amerikai Egyesült Államok) gélfuttató rendszert alkalmaztunk EPS 3501 XL (Amersham Biosciences, Little Chalfont, Egyesült Királyság) és EPS 500/400 (Pharmacia LKB, New Jersey, USA) tápegységekkel.

\subsubsection{Natív poliakrilamid gélelektroforézis}

Natív poliakrilamid gélelektroforézis [139] során nem alkalmazunk olyan denaturáló ágenst, sem a gélben, sem a minta előkészítés során, amely miatt a szolúbilis fehérjék irreverzibilis módon elveszítenék natív konformációjukat. Ennek köszönhetően 


\section{Anyagok és módszerek}

megmarad a fehérjék jellemző felületi töltése, alakja, aktivitása, és nem válnak szét alegységeikre. A poliakrilamid gél térhálójában az elválasztás során a relatív futási sebességet a fehérjék molekulasúlya, alakja és fajlagos töltése egyaránt befolyásolja.

A natív gél két részből áll. A gyüjtő gél 3,13\%, a szeparáló gél $6,5 \%$ összakrilamid koncentrációval bírt. A gyüjtő gél $1 \mathrm{~cm}$ magas volt. A natív gélek pontos összetételét az 2. táblázat tartalmazza.

\begin{tabular}{|l|c|c|}
\hline \multicolumn{1}{|c|}{ Összetevő } & $\begin{array}{c}\text { Gyüjtő gél } \\
\text { (végkoncentráció) }\end{array}$ & $\begin{array}{c}\text { Szeparáló gél } \\
\text { (végkoncentráció) }\end{array}$ \\
\hline Akrilamid/Bisz-akrilamid & $3,125 \% \mathrm{~T}, 5 \% \mathrm{C}$ & $6,5 \% \mathrm{~T}, 20 \% \mathrm{C}$ \\
\hline $\begin{array}{l}\text { Gélpuffer törzsoldat } \\
\text { (Tris-HCl, pH 8,5) }\end{array}$ & - & $239,25 \mathrm{mM}$ \\
\hline $\begin{array}{l}\text { Gélpuffer törzsoldat } \\
\text { (Tris- } \mathrm{H}_{3} \mathrm{PO}_{4}, \mathrm{pH} \text { 6,9) }\end{array}$ & $39,5 \mathrm{mM}$ & - \\
\hline Ammónium-perszulfát & $0,0053 \mathrm{~m} / \mathrm{v} \%$ & $0,0022 \mathrm{~m} / \mathrm{v} \%$ \\
\hline TEMED & $0,002 \mathrm{v} / \mathrm{v} \%$ & $0,005 \mathrm{v} / \mathrm{v} \%$ \\
\hline
\end{tabular}

2. táblázat: A natív poliakrilamid gél összetétele.

$\%$ T: az akrilamid és a bisz-akrilamid együttes koncentrációja $(\mathrm{m} / \mathrm{v} \%)$ az oldatban. \% C: a biszakrilamid koncentrációja a T \%-ben.

A kivonatokat mintafelvivő pufferrel 1:9 arányban (puffer : minta) keverve mértük a kimosott zsebekbe, Hamilton fecskendő segítségével. A puffer 50\% szacharózt és $0,1 \%$ brómfenolkéket tartalmazott. A nagy mennyiségü szacharóznak köszönhetően a minta a zseb aljára süllyed. A brómfenolkék a futási frontot teszi követhetővé. A fehérjéket $200 \mathrm{~V}$ feszültséggel, $25 \mathrm{~m} \mathrm{~A}$ áramerősséggel futtattuk a brómfenolkék kifuttatása utáni ötödik percig.

Elektroforézis során az emelkedő hőmérséklet zavarhatja a futtatást, a fehérje sávok elkenődését, a futási front hullámosodását, görbülését okozhatja. A túlmelegedés elkerülése, tehát az elválasztás sikere és a fehérje aktivitásának megőrzése érdekében, a futtatás során a katód puffert hütöttük. A katód puffer összetétele $40 \mathrm{mM}$ glicin, 37,6 mM Tris pH 8,89, az anód puffer összetétele 63 mM Tris-HCl, pH 7,47 volt.

A géleket a GS izoenzimek szeparálására és a GS2 izoenzim tisztítására használtuk fel. 


\section{Anyagok és módszerek}

\subsubsection{Kétdimenziós poliakrilamid gélelektroforézis}

A GS izoenzimek kétdimenziós elválasztása során az első dimenziós elválasztást natív poliakrilamid gélelektroforézissel végeztük. A második dimenzióban denaturáló SDS-poliakrilamid gélelektroforézist (SDS-PAGE) alkalmaztunk [140]. A denaturálás következményeképpen a fehérjealegységek szétválnak, elveszítik natív konformációjukat. A denaturált, szerkezeti sajátosságait elvesztett fehérjék felszínén a nátrium-dodecil-szulfát (SDS) mint anionos detergens egységes negatív töltést biztosít, lehetővé téve ezzel a fehérjék molekulatömeg szerinti elválasztását.

A natív PAGE után a futtatás irányában egy teljes, körülbelül zseb szélességü sávot metszettünk ki, és vittük tovább második dimenzióban való elválasztásra. A kimetszett sávot 0,5 M Tris- $\mathrm{HCl}(\mathrm{pH}$ 6,5), $10 \mathrm{v} / \mathrm{v} \%$ glicerol, 32,5 mM dithiothreitol, $2 \%(\mathrm{~m} / \mathrm{v}) \mathrm{SDS}, \quad 2 \%$ ß-merkaptoetanol, $0,02 \%$ Servablue-G-t tartalmazó oldatban rázattuk 2-szer 60 percig szobahőmérsékleten. Ezzel a lépéssel beállítjuk a gélszelet kémhatását és denaturáljuk a benne natív PAGE-vel szeparált fehérjéket. Futtatás előtt a gélszeletet $3 \mathrm{~mm}$-rel a gyüjtő gél fölé csúsztattuk, 1\%-os agarózba ágyaztuk. A gyűjtő gél magassága $7 \mathrm{~mm}$ volt. Az SDS gélek pontos összetételét a 3. táblázat tartalmazza.

A katódpuffer (pH 8,25) 0,1 M Tris-t, 0,1 M tricint és 0,1\% SDS-t tartalmazott. Anód pufferként (pH 8,9) 0,2 M Tris-HCl oldatot alkalmaztunk.

A géleket $200 \mathrm{~V}$ feszültséggel és $80 \mathrm{~mA}$ áramerősséggel futtattuk 90 percig. Precision Plus Protein ${ }^{\mathrm{TM}}$ Kaleidoscope ${ }^{\mathrm{TM}}$ standardet (Bio-Rad, Hercules, California, Amerikai Egyesült Államok) használtunk molekulasúly markerként.

\begin{tabular}{|c|c|c|}
\hline Komponens & $\begin{array}{c}\text { Gyüjtö gél } \\
\text { (végkoncentráció) }\end{array}$ & $\begin{array}{c}\text { Szeparáló gél } \\
\text { (végkoncentráció) }\end{array}$ \\
\hline Akrilamid/Bisz-akrilamid & $4 \% \mathrm{~T}, 3 \% \mathrm{C}$ & $10 \% \mathrm{~T}, 3 \% \mathrm{C}$ \\
\hline Gélpuffer & $0,75 \mathrm{M}$ Tris & $1 \mathrm{M}$ Tris \\
$(\mathrm{pH} 8,5)$ & $0,075 \% \mathrm{SDS}$ & $0,1 \% \mathrm{SDS}$ \\
\hline Ammónium-perszulfát & $0,0056 \%$ & $0,0056 \%$ \\
\hline TEMED & $0,056 \%$ & $0,056 \%$ \\
\hline Glicerin (87\%) & - & $9,4 \%$ \\
\hline
\end{tabular}

\section{3. táblázat: a denaturáló poliakrilamid gél összetétele.}

$\% \mathrm{~T}$ : az akrilamid és a bisz-akrilamid együttes koncentráció. \% C: a bisz-akrilamid koncentrációja a T \%-ben. 


\section{Anyagok és módszerek}

\subsection{A glutamin-szintetáz in vitro aktivitás mérése}

A kísérlethez nyers vagy tisztított fehérjeextraktumot használtuk. A GS által katalizált reakció során ha az ammóniumion helyett hidroxilamint alkalmazunk, módosított szintetáz reakció zajlik le, melynek végtermékeként GMH [126].

A GMH savas közegben $\mathrm{Fe}^{3+}$ ionokkal sárgásbarna színű komplex vegyületet alkot (9. ábra). A GMH keletkezése és a GS specifikus aktivitása egymással egyenes arányosságban áll, tehát a GMH-val képzett komplex mennyisége közvetlen információt ad az enzim aktivitásáról. A képződött komplex mennyisége 540 nm hullámhossznál spektrofotometriásan nyomon követhető.

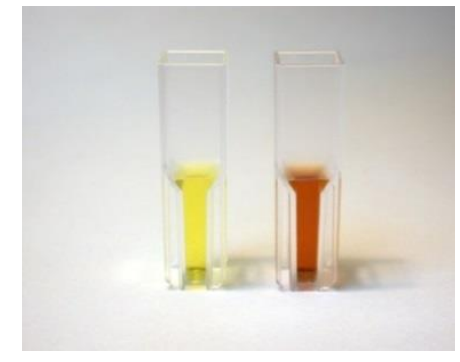

\section{9. ábra: A glutamin-szintetáz aktivitás mérésekor lejátszódó színreakció.}

Balról a terméket nem tartalmazó, jobbról a $\gamma$-glutamil-monohidroxamátot tartalmazó küvetták a vas-kloridos savas oldat hozzáadása után.

A reakcióelegy $75 \mu \mathrm{l}$ mintát, $200 \mu \mathrm{l}$ reakció puffert tartalmazott. Az alap reakciópuffer végkoncentrációban $21 \mathrm{mM}$ magnézium-kloridot, $36 \mathrm{mM}$ imidazolt, $15 \mathrm{mM}$ ATP-t, és $30 \mathrm{mM}$ glutaminsavat tartalmazott. A reakció puffer összetételét kísérleteinkben a tanulmányozni kívánt szubsztrátum, vagy termék vizsgálhatóságának megfelelően változtattuk:

- ATP: 0-25 mM

- Glutaminsav: 0-200 mM

- glutamin: 0-57 $\mathrm{mM}$

- GMH: 0-80 nM

A reakciót $\quad 400 \mu \mathrm{lstop} \quad$ oldat $\quad\left(300 \mathrm{mM} \mathrm{FeCl}_{3} \cdot 6 \mathrm{H}_{2} \mathrm{O}, \quad 670 \mathrm{mM} \mathrm{HCl}\right.$, 200 mM triklór-ecetsav) hozzáadásával állítottuk le, amit a minták azonnali homogenizálása követett. Az erősen savas közegnek és a triklór-ecetsavnak köszönhetően a stop oldat hozzáadásával az addig oldatban lévő fehérjék denaturálódnak, így azonnal megállítjuk az enzimműködést, ezáltal a termékképződést. 


\section{Anyagok és módszerek}

A komplex kialakulására legalább 30 percet vártunk, ez alatt a mintákat szobahőmérsékleten tartottuk. Ezzel egy időben a savas közeg hatására a biológiai mintából származó anyagok, más fehérjék, nukleinsavak kicsapódásának is elegendő időt hagytunk.

A kicsapódott pelletet 10 perc, $13000 \mathrm{~g}$ centrifugálással ülepítettük az Eppendorf cső aljára. A felülúszó fényelnyelését 540 nm-nél Uvikon XL (Secomam, Franciaország) spektrofotométerrel mértük eldobható polimetil-metakrilát küvettákban.

\subsection{A GS aktivitása poliakrilamid gélben}

A natív konformációjú GS izoenzimek helyét a poliakrilamid gélben azok aktivitása alapján határoztuk meg. A natív géleket futtatás után $50 \mathrm{mM}$ imidazol és $18 \mathrm{mM} \mathrm{MgCl} 2 \cdot 6 \mathrm{H}_{2} \mathrm{O}$ tartalmú oldatba helyeztük, hogy a gélben beállítsuk az enzimmüködéshez megfelelö kémhatást és magnézium ellátottságot. Ebben a puffer oldatban a gélt szobahőmérsékleten rázattuk 2-szer 10 percig. A lecserélt oldatok kémhatását mérve ellenőriztük a pufferelés hatékonyságát. A gélt ez után reakció elegyben áztattuk 20 percig, $30^{\circ} \mathrm{C}$-on.

A stopreagens hozzáadásával állítottuk le a reakciót és tettük láthatóvá a GS izoenzimeket, melyek helyét egy-egy sárgásbarna sáv megjelenése jelezte. A gélt szkenner segítségével azonnal dokumentáltuk, megelőzve a végtermék diffúzióját.

\subsection{Tisztított GS2 izoenzim izolálása}

A nem-denaturáló gélelektroforézissel elválasztott fehérjék futtatás után is megtartják aktivitásukat. A GS izoenzimek könnyen lokalizálhatók natív gélen, mivel a GS aktivitás mérése eredményeképpen szabad szemmel látható a szubsztrátum képződése.

Kísérleteinkben a nyers fehérje extraktumot a fent tárgyalt módszerrel natív poliakrilamid gélen futattuk. A gél egy szeletén aktivitásvizsgálatot végeztünk, a korábbiakban leírt módon, a gél többi részét $4{ }^{\circ} \mathrm{C}$-on, a kiszáradástól védve tároltuk. Az aktív sáv helyének meghatározása alapján az addig eltárolt gélből kimetszettük a GS2 izoenzimet tartalmazó sávot (10. ábra). 


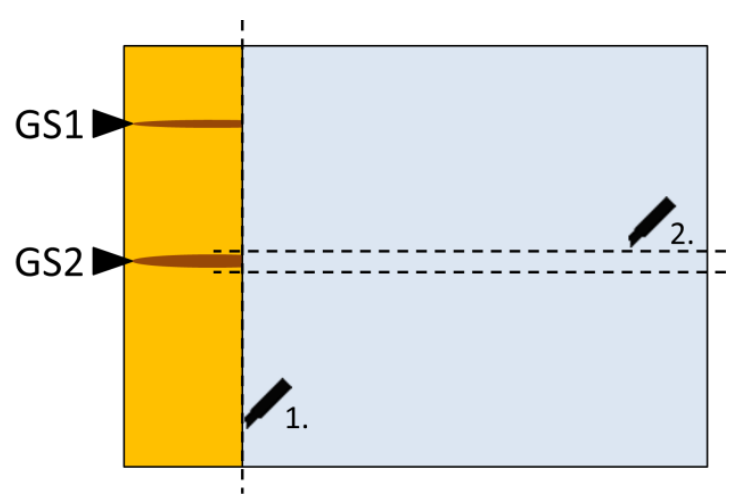

10. ábra: Intakt glutamin-szintetáz alegységek lokalizálása natív gélben.

Az alegységek helyzetét aktivitásuk mutatja, ez alapján a gél festetlen részén a GS helyzete feltérképezhetö. 1.: A gél egy szeletének leválasztása a GS izoenzimek lokalizációjához, aktivitás alapján. 2.: A GS2-t tartalmazó gélszelet izolálása

A gélszeleteket jégen hütött mozsárban, jéghideg kivonó pufferben homogenizáltuk. Centrifugálás után $\left(10\right.$ perc, $\left.13000 \mathrm{~g}, \quad 4^{\circ} \mathrm{C}\right)$ a felülúszót összegyüjtöttük és frissen használtuk kinetikai méréseinkhez. Fagyasztás után a minta nem használható kinetikai mérésekhez.

A minta tisztulását SDS poliakrilamid gélen ellenőriztük. Ehhez ugyanazt a módszert használtuk, mint amit a kétdimenziós elválasztás második dimenziójaként is alkalmaztunk.

\subsection{Protein blot}

A fehérjék elektroforetikus elválasztását követően a GS izoenzimek lokalizációját immunoblot segítségével állapítottuk meg. A módszer lényege, hogy a poliakrilamid gélt vagy géleket elektromos térbe helyezzük, ahol a fehérjék a futás irányában haladva végül egy membrán felületén csapdázódnak. A fehérjéket festési eljárással tehetjük láthatóvá a membránon [141,142].

Kísérleteinkben „semi-dry” blottolást alkalmaztunk, melyhez Multiphore II (Pharmacia, Stockholm, Svédország) készüléket használtunk. A készülék anód (4 v/v\% metanolt tartalmazó $50 \mathrm{mM}$-os bórsav oldat, pH 9,0) illetve katód (50 mM-os bórsav oldat pH 9,0) pufferrel megnedvesített grafit lapjai közé buborékmentes blotszendvicset állítottunk össze. A szendvics anód (alsó) oldalára anód pufferrel átitatott, méretre szabott Whatman 3MM papírt halmoztunk, melyre pontosan illeszkedő, megfelelően előkészített polivinilidén-difluorid (PVDF) membránt helyeztünk. Erre tettük 


\section{Anyagok és módszerek}

az alábbiak szerint átpufferelt géleket, melyek tetejére katód pufferrel átitatott, méretre szabott Whatman papírt helyeztünk.

A futtatás után a poliakrilamid géleket katódpufferben rázattuk 20 percig, szobahőmérsékleten. A blottolást $100 \mathrm{~V}$ feszültséggel, $1 \mathrm{~mA} / \mathrm{cm}^{2}$ áramerősséggel 90 percen keresztül végeztük egy korábban leírt módszer szerint [126].

A blottolás után a GS alegységeit festési eljárással kellett láthatóvá tenni a membránon. A membránon lévő nem specifikus kötőhelyeket albuminnal telítettük. A blokkoláshoz a száradás után újranedvesített membránokat 2 órán át, enyhe rázatással (MR-1 Mini-Rocker Shaker, BioSan) blokkoltuk 5\% albumint tartalmazó TBS oldatban (20 mM Tris- $\mathrm{HCl}-\mathrm{pH} 7,4,150 \mathrm{mM} \mathrm{NaCl})$.

A membránokat elsődleges, poliklonális GS-antitesttel kezeltük egy éjszakán át, enyhén rázatva, $7^{\circ} \mathrm{C}$-on. A nem kötött antitesteket eltávolítása érdekében, a membránokat 30 percig mostuk TTBS oldatban (0.05 v/v \% TWEEN 20 detergenst tartalmazó TBS oldat. A membránra így felvitt TWEEN-20 detergens TBS oldattal mostuk le. Ezután a membránokat másodlagos antitesttel, alkalikus foszfatázzal konjugált Protein-A-val (ajánlott hígítás:1:20 000) kezeltük 1 órán át, szobahőmérsékleten [126], amit egy 30 perces TTBS, majd 30 perces TBS oldatos mosás követte. A mosási lépések alatt az oldatokat többször cseréltük. Ezután a membránt 5 percre $0,1 \mathrm{M}$ Tris- $\mathrm{HCl}$ - $\mathrm{pH}$ 9,0 és 0,1 M NaCl-t tartalmazó oldatban rázattuk, hogy a beállítsuk az alkalikus foszfatáz müködéséhez optimális kémhatást. A foszfatáz reakcióhoz használt reakcióelegy összetétele a következőképpen alakult: 0,1 M Tris- $\mathrm{HCl}-\mathrm{pH} 9,0,0,1 \mathrm{M} \mathrm{NaCl}, 5 \mathrm{mM} \mathrm{MgCl} \mathrm{Mg}_{2} \cdot 6 \mathrm{H}_{2} \mathrm{O}, 135 \mu \mathrm{g} / \mathrm{ml}$ 5-bromo4-kloro-3-indolil-foszfát (BCIP), 262,5 $\mu \mathrm{g} / \mathrm{ml}$ 4-nitro-tetrazóliumkék (NBT).

A BCIP az alkalikus foszfatáz szubsztrátja. A BCIP defoszforilációját követően képződő termék az NBT-vel reagálva lila vegyületet hoznak létre. A BCIP és NBT fényérzékeny, bomlékony anyagok, emiatt az előhívást sötét, zárt edényben végeztük. A színreakció pontosan jelzi a GS izoenzimek helyét a membránon, melynek segítségével azok helye a Coomassie Brilliant Blue G (CBBG) festett géleken is meghatározható. 


\subsection{Poliakrilamid gélek festése, szárítása, dokumentálása}

A festésre, tárolásra szánt géleket legalább 50 percig $10 \% \mathrm{v} / \mathrm{v}$ ecetsavat és $40 \%$ v/v metanolt tartalmazó oldatban fixáltuk. Ezt követően $0.0025 \%$ CBBG festéket tartalmazó 10\%-os ecetsav oldattal festettük 15 percig, majd a háttér elszíntelenedéséig $10 \%$ ecetsav oldatban áztattuk, hogy a fehérje mintázatot láthatóvá tegyük. [143]

A poliakrilamid géleket nagy felbontású asztali lapszkenner (CanoScan LiDE 210, Canon, Tokió, Japán) segítségével dokumentáltuk, egységes, fehér háttérrel. A géleket nedves Whatman papírra helyezve, fóliával fedve BioRad Gel Dryer Model 583 készülékkel (Bio-Rad, Hercules, California, Amerikai Egyesült Államok) $70{ }^{\circ} \mathrm{C}$-on, vákuumban 50 perc alatt szárítottuk, tárolhatóvá tettük.

\subsection{Fémionok hatásának vizsgálata az in vitro GS aktivitásra}

Aktivitásvizsgálataink során a magnéziumot $\mathrm{MgCl}_{2}$, a mangánt $\mathrm{MnSO}_{4}$ illetve $\mathrm{MnCl}_{2}$ formájában, az alumíniumot pedig alumínium(III)-nitrilotriecetsav (Al(III)NTA) formában adtuk hozzá a reakcióelegyhez optimális magnéziumkoncentráció mellett. A glutaminsavat növekvő koncentrációban adagoltuk, állandó fémionkoncentráció mellett. Az alumínium enzimaktivitást növelő hatása korábbról ismert [126], 6,8 mM Al(III)NTA hozzádása mellett tanulmányoztuk a glutamin (GMH) képződést. A mangán hatását 0-30 $\mathrm{mM} \mathrm{MnCl}_{2}$, valamint 0-30 $\mathrm{mM} \mathrm{MnSO}_{4}$ koncentrációsorokon vizsgáltuk, a korábban meghatározott optimális $18 \mathrm{mM}$-os magnézium ellátottság mellett. A mangán hatását a GS aktivitására 0,2 ; és $0,4 \mathrm{mM}$ mangántartalom mellett vizsgáltuk 0-30 mM glutaminsav koncentrációsoron.

\subsection{A mangán és magnézium detektálása}

A GS2-t tartalmazó nyers fehérje kivonat egy részét mangán-kloriddal kezeltük. A kezelt és kezeletlen mintákat külön natív géleken futtattuk, majd a már dolgozatomban bemutatott módszerrel a GS2-t izoláltuk a gélekből. Gélenként $700 \mu \mathrm{g}$ fehérjét futtattunk. A kimetszett szeleteket felhasználásig $-20^{\circ} \mathrm{C}$-on tároltuk. 


\section{Anyagok és módszerek}

A GS2-t tartalmazó gélszelet magnézium- és mangántartalmát induktívan csatolt plazma tömegspektrometria (ICP-MS, Thermo Scientific XSeries II, Asheville, USA) technikával határoztuk meg. Az oldatba vitt mintákat aeroszolként befecskendezve a plazma ionizálja és a nyomáskülönbség juttatja az ionokat a tömegspektrométerbe. A vizsgálathoz a mintákat salétromsavas, hidrogén-peroxidos közegben, mikrohullámú roncsolással tártuk fel [144].

\subsection{Az aktivitásmérések értékelése}

A vizsgálatokat legalább 3 független kísérletben ismételtük, kivételt képez a 13b ábrán szereplő tisztított fehérjével végzett ATP-telítési kinetikai vizsgálat, melyet két alkalommal végeztünk el. A bemutatott ábrákon a legreprezentatívabb eredményeket tüntettem fel.

A mérési sorozatokra történő nem lineáris görbeillesztést SigmaPlot@ (Systat Software, San Jose, California) program segítségével végeztük. A különböző kinetikai modelleket a szofver Enzyme Kinetics modulja segítségével hasonlítottuk össze. A modellek rangsorolásának alapja a „corrected Akaike Information Criteria Index” (AICc) volt, amely egy megfelelő, dimenzió nélküli statisztikai mérőszám modellek összehasonlításához. Az értékek önmagukban nem értelmezhetők, csak összehasonlításra használhatók.

Az összehasonlítások során a legkisebb érték jellemzi a legmegfelelőbb modellt, de nem hagyhatjuk figyelmen kívül a többi modelltől való eltérés mértékét. A modellek összehasonlítása során az 5 egység fölötti különbséget nagyon valószínü eltérésnek, a 10 egység fölötti különbséget egyértelműen különbözőnek értelmezzük.

Az értékelő program algoritmusa a legjobban illeszkedő függvények paraméterei alapján kalkulálja a kinetikai paramétereket. Ez egy sokkal objektívebb módja az értékelésnek, mint a „kézi” számítások, ahol az adatok logaritmikus transzformációja mellett, a transzformációk eredményeként kapott függvények lineáris szakasza szubjektíven megválasztható. Ezek a lineáris szakaszok szolgálnak a paraméterek meghatározására. Hátránya a szoftveres értékelésnek, hogy bár a programok müködésének megértése egyszerü, új modulok helyes beépítése már komolyabb programozási ismereteket igényel, és részletes program dokumentációval is nehézséget jelent számítástechnikai jártasság nélkül. 
4. Anyagok és módszerek 


\section{Eredmények}

\subsection{Szubsztrátumszintű szabályozás vizsgálata}

A GS központi helyet foglal el az anyagcseretérképen. A növényi nitrogén asszimiláció enzimeinek láncolatában ez az első enzim, amely a szervetlen nitrogénforrást, az ammóniát szénvázhoz, azaz glutaminsavhoz köti. Mind a nitrát redukciója, mind a szénváz generálása energetikailag igen költséges. Az anyagcsereutak kapcsolódási pontjánál szükséges egy olyan szabályozási mechanizmus, amely megfelelően gondoskodik mindkét útvonal szubsztrátum-ellátottságáról. Enzim szinten ilyen szabályozási lehetőséget nyújt az allosztéria.

Hipotézisünk szerint a búza növényben a GS olyan szubsztrátumszintű szabályozással rendelkezik, melynek köszönhetően képes a kapcsolódó szén- és nitrogénanyagcsere-utak közötti egyensúly megtartásának elősegítésére. A búzalevél össz GS aktivitása legalább 80\%-ban a plasztiszban lokalizált GS2 izoformától ered, ezért vizsgálataink célja elsősorban ezen izoenzim müködési sajátosságainak felderítése.

\subsubsection{Az enzim alegység összetételének vizsgálata}

A GS-t több alegységes enzimként írták le, több organizmusban, melyeknél feltételezik a homogén alegység-összetételt. Az allosztérikus szabályozás vizsgálatához ismernünk kell a fehérje alegység-összetételének esetleges heterogenitását a későbbi eredmények helyes értelmezéséhez.

Vizsgálatainkhoz natív és SDS PAGE kombinációját alkalmaztuk, az izoenzimeket immunoblot segítségével tettük láthatóvá. Natív PAGE során a fehérjék futási mobilitását felületi töltésük, molekulatömegük és alakjuk együttesen határozza meg. Az első dimenzióban a natív elválasztás két különálló sávot eredményezett (11a ábra), ezek a GS1 és GS2 izoenzimek, melyek közül a GS2 a mobilisabb. Kétdimenziós elválasztás során a második dimenzióban a GS1 és GS2 egy-egy különálló foltot adott (11b ábra), melyek molekulatömege rendre 41,7 kDa és 46,4 kDa, az alkalmazott marker alapján. A vizsgálatok során tehát csak az egyes izoenzimekre egyedileg jellemző molekulatömegü fehérjéket találtunk. 


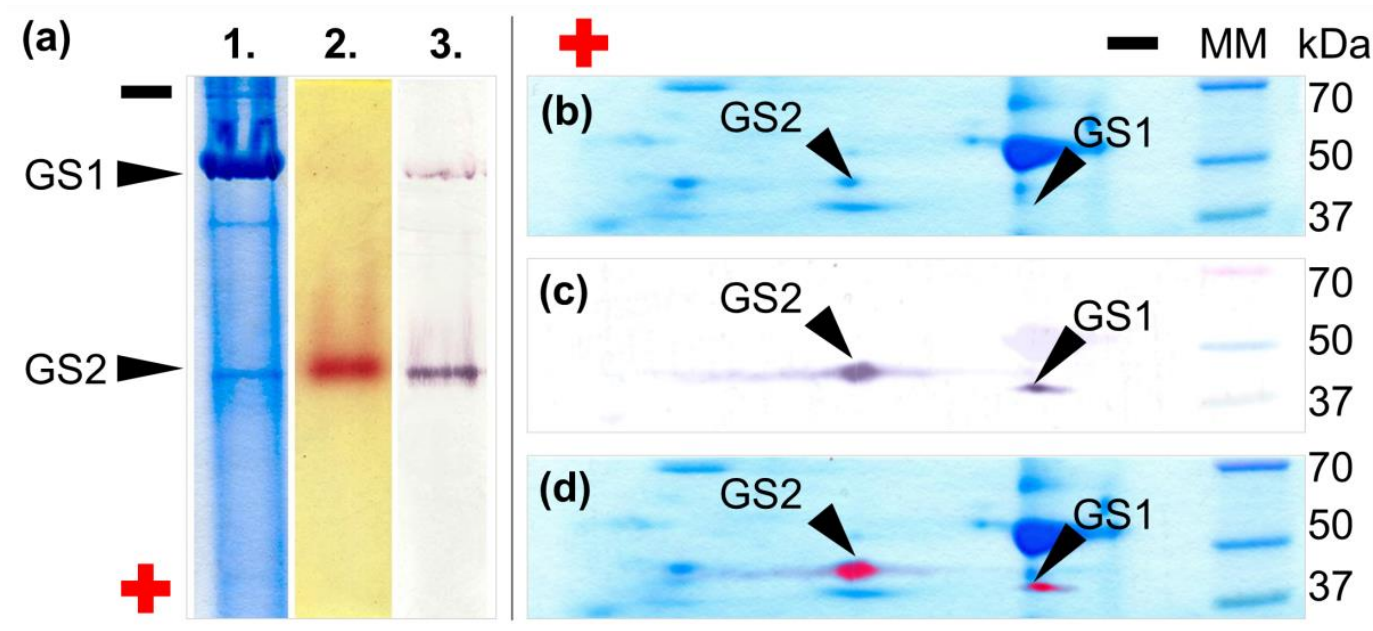

\section{1. ábra: A levélből származó glutamin-szintetáz enzimek azonosítása kétdimenziós elválasztással.}

(a) Az izoenzimek elválasztása natív poliakrilamid gélelektroforézissel (első dimenzió). 1.- Coomassie Brilliant Blue $G$ festés. 2.- Enzim aktivitás gélben. 3.- Immunoblot. (b-d) Izoenzimek elválasztása molekulatömegük alapján SDS denaturáló gélelektroforézissel (második dimenzió). (b) 2D gél, CBBG festés. (c) A 2D immunoblot, a szeparált GS izoenzimek. (d) Az előző két kép digitális illesztése, a GS1 és GS2 azonosítása a 2D gélen. A molekulasúly markereket (MM) a jobb oldalon jelöltem. A plusz és mínusz jelölések az első dimenzió gél szeletének anód és katód oldalát jelölik.

Mivel csak az egyedi jeleket kaptuk, kizárható annak lehetősége, hogy a natív PAGE elválasztásnál a kapott GS-t tartalmazó sávokban vagy azok közvetlen közelében az izoenzimek esetlegesen effektor proteinhez kovalensen kötve lennének jelen.Ennek értelmében a natív gélekből, az aktivitás alapján lokalizált GS2-t tartalmazó fehérjesávból, nagy valószínüséggel intakt homomer GS2 oligomerek izolálhatók.

\subsubsection{Szubsztrátumok hatásának vizsgálata}

A szubsztrátumok hatásának vizsgálata során kapott kinetikai görbéket a $V_{\max }$, maximális sebesség, a $K_{s}$, a maximális sebesség feléhez tartozó szubsztrátumkoncentráció, illetve ahol szükséges, az n, Hill koefficiens értékekkel jellemeztük. A következőkben ez a terminológia használatos. 


\subsubsection{A hidroxilamin hatása}

A GS által katalizált reakcióban a glutaminsav egy ATP molekula hasítása mellett alakul glutaminná. Az in vitro aktivitás vizsgálataink során ammóniumdonorként hidroxilamint használtunk. A nyers fehérjeextraktum GS aktivitását hidroxilamin koncentrációsoron vizsgáltuk. Megvizsgáltuk, a glutaminsav hogyan befolyásolja a görbe lefutását (12. ábra).

A kinetikai görbe rendkívül meredeken indul és hamar telítődik - a továbbiakban ismertetett görbékhez képest. A görbén nincsenek jellegzetes, reprodukálható töréspontok, melyek glutaminsav-ellátottságtól függetlenül minden görbén megjelennek. A mérési sorokra összességében legnagyobb pontossággal AICc indexük alapján M-M kinetika illeszthető. Az így jellemezhető telítődés arra utal, hogy az ammóniumionnak nincs allosztérikus hatása.

A görbék telítési maximumai, vagyis az egyes görbékhez tartozó $V_{\max }$ értékek a glutaminsav-ellátottság függvényében nőnek. A mérési sorozatokra M-M kinetikát illesztve azt az eredményt kaptuk, hogy a legalacsonyabb, $1 \mathrm{mM}$ glutaminsavat tartalmazó sorozattól eltekintve, a $\mathrm{K}_{\mathrm{s}}$ értékek a glutaminsav ellátottsággal növekvő tendenciát mutatnak. A kalkulált értékek a III. mellékletben találhatók.

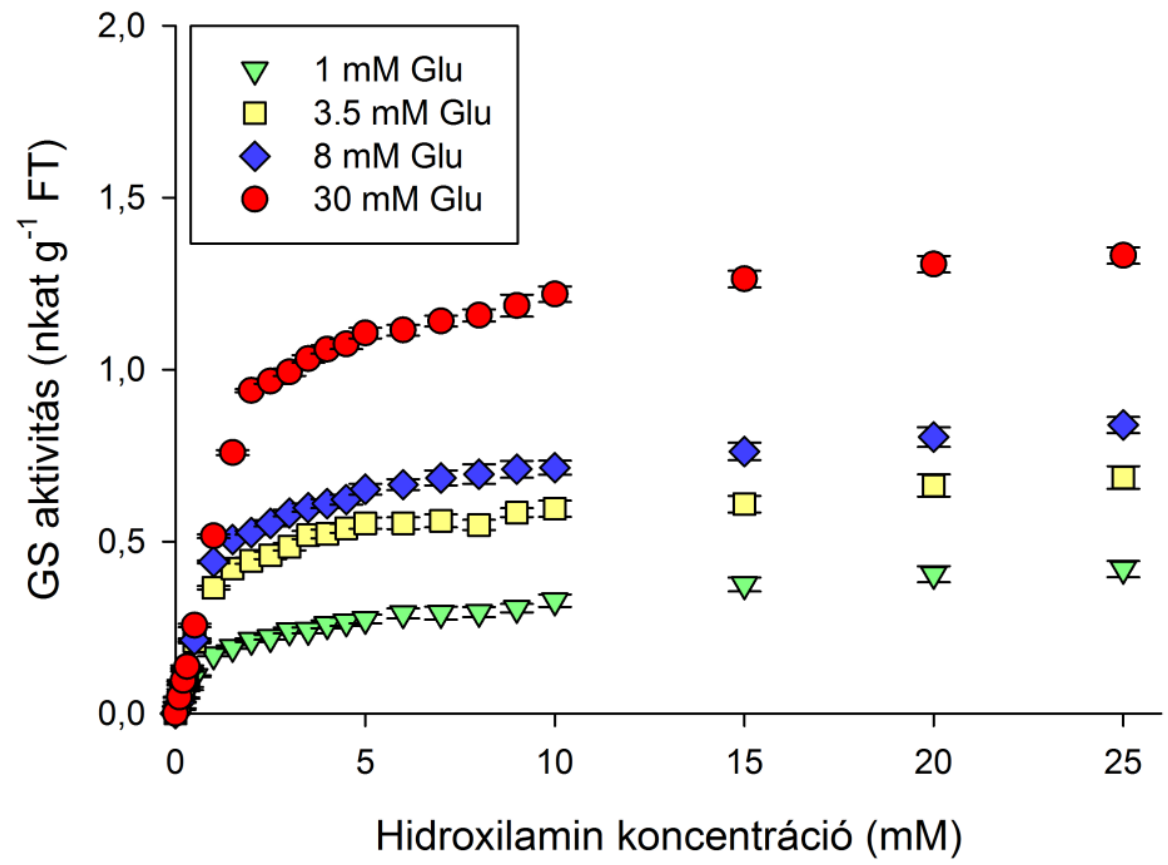

12. ábra: A GS hidroxilamin telítési kinetikája nyers kivonatban.

A telítés már alacsony hidroxilamin-koncentrációnál bekövetkezik bármely glutaminsav-ellátottságnál. 


\section{Eredmények}

Az 1 mM-os glutaminsav-ellátottsághoz tartozó sorozat kinetikai görbéjének telítés előtti szakasza rendkívül rövid. $\mathrm{A} \mathrm{K}_{\mathrm{s}}$ érték meghatározása erre a szakaszra esik. Ebben az alacsony koncentráció-tartományban a nyers enzimkivonattal végzett stopreakción alapuló mérési módszer valószínűleg már nem elég érzékeny a $\mathrm{K}_{\mathrm{s}}$ érték pontos meghatározásához. Ez okozhatta, hogy $1 \mathrm{mM}$ Glu mellett magasabb $\mathrm{K}_{\mathrm{s}}$ értéket mértünk, mint a többi esetben.

A $\mathrm{K}_{\mathrm{s}}$ értékek 1,5 mM-nál alacsonyabbak, ami nagy ammóniumion-affinitásra utal. A gyors telítődés, az ammónia effektív felhasználása, az eddig jellemzett GS-ek közös jellemzője [145].

\subsubsection{Az ATP hatásának vizsgálata}

Az enzim aktivitását ATP koncentráció soron vizsgáltuk 4 féle glutaminsav koncentráción (13. ábra). A kinetikai görbék kezdeti szakaszára nem jellemző olyan hirtelen emelkedés, mint amit a hidroxilamin esetében tapasztaltunk, de a jobb glutaminsav-ellátottság egyértelműen pozitívan befolyásolta a maximális sebességet.
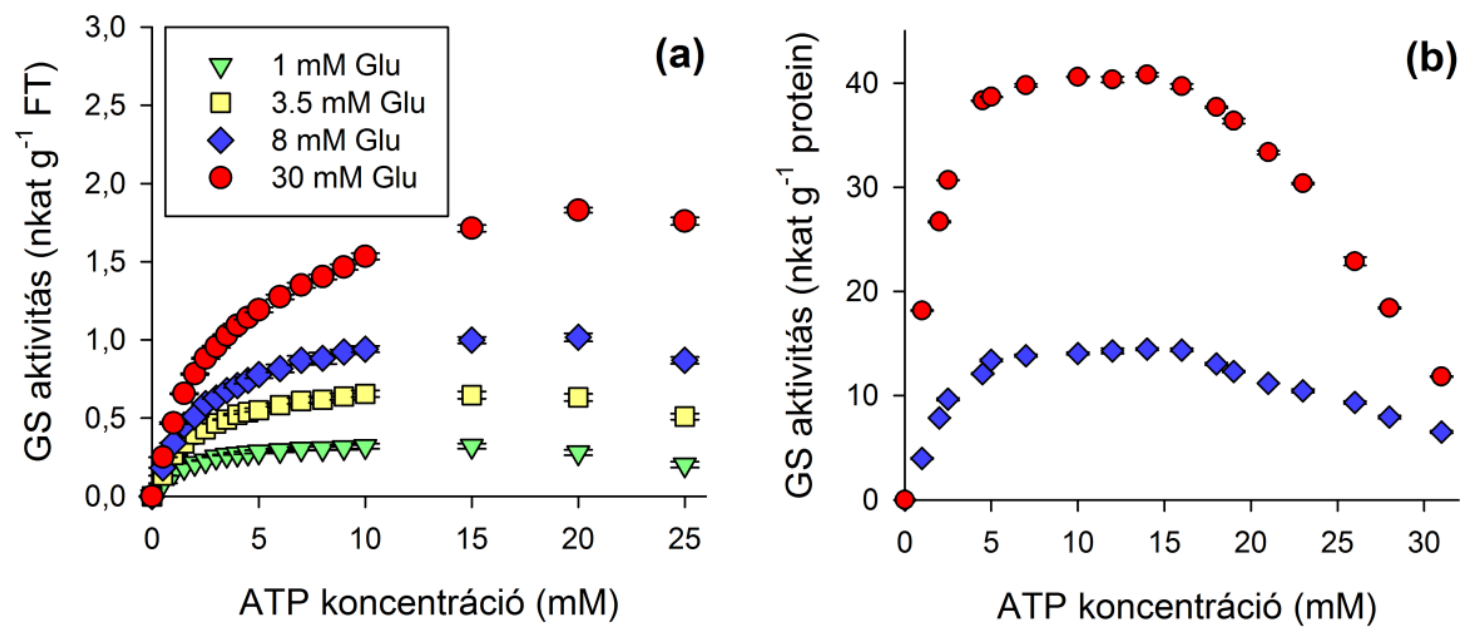

13. ábra: Az össz GS aktivitás és a tisztított GS2 aktivitása az ATP függvényében.

(a) Nyers, illetve (b) tisztított enzimkivonatban mért aktivitás. Míg nyers kivonatban csak kis mértékben, addig tisztított kivonatban erőteljesebben mutatkozik meg magas koncentráción az ATP gátló hatása.

Az aktivitás minden vizsgált glutaminsav-koncentráció mellett a maximális sebesség eléréséhez szükséges ATP koncentráció fölötti tartományban ( $20 \mathrm{mM}$ fölött) enyhe csökkenést mutat. Feltehetőleg ez már bőven kívül esik a fiziológiás tartományon, amely irodalmi adatok alapján nem több, mint néhány, 3-5 mM [146]. 


\section{Eredmények}

Mivel az ATP hasításának energiájára szükség van a katalitikus folyamat lejátszódásához, feltételezzük, hogy az enzim in vivo müködése során a maximális reakciósebesség eléréséig nem lép fel gátló hatás.

A nyers enzimkivonatban jelen vannak más ATP-t használó enzimek, amelyek befolyásolhatják mérési eredményünket. Hogy az ebből fakadó hátteret megszüntessük, megvizsgáltuk az ATP hatását a tisztított enzimkivonatra is, két glutaminsav-koncentráció mellett. Az aktivitás drasztikus csökkenése 15 mM ATP koncentráció fölött egyértelmüen mutatja a korábban tapasztalt gátló hatást. A 13a ábrán bemutatott görbék kinetikai paramétereit az IV. melléklet mutatja be. A gátlást egyértelműen bemutató kinetikai görbe helyes analíziséhez ismerünk jól illeszkedő modellt. Az ATP kiváltotta inhibíció jelensége publikációnk közléséig nem volt ismert a szakirodalomban [147].

\subsubsection{Glutaminsav telítési kinetikák}

A glutaminsav amellett, hogy jelentős biokémiai intermedier, és feltételezik jelátviteli szerepét $[15,108,112]$, a GS által katalizált bioszintetikus reakció természetes szubsztrátuma.

Megvizsgáltuk az enzim aktivitását egy szélesebb glutaminsav-koncentrációnál, 0-200 mM-on (14a ábra), hogy a kinetikai görbe elejét és végét is nagy pontossággal tudjuk karakterizálni. Elvégeztük tehát a görbe szoftveres analízisét, amely azt mutatta, hogy a mérési eredményünket legnagyobb valószínüséggel és pontossággal a Hill egyenlőség jellemzi, melynek kinetikai paraméterei $n=0.792 \pm 0.018$ (Hill koefficiens), $\quad K_{s}=22.38 \pm 1.44 \mathrm{mM} \quad$ és $\quad V_{\max }=273.08 \pm 5.44$ nkat $^{-1}$ friss tömeg. Az $n<1$ érték arra utal, hogy negatív kooperativitás áll fenn az enzim müködése során. Annak érdekében, hogy elimináljuk a GS1 jelenlétéből fakadó hátteret, a kísérletet tisztított GS2 enzimmel is elvégeztük. A Hill egyenlet AICc értéke legalább 12 ponttal volt jobb a többi modelltől (V. melléklet). A kapott paraméterek a következőképpen alakultak: $n=0.711 \pm 0.056, \quad \mathrm{~V}_{\max }=425.23 \pm 107.59$ nkat $\mathrm{g}^{-1}$ fehérje és $\mathrm{K}_{\mathrm{s}}=285.76 \pm 179.47 \mathrm{mM}$.

A szubsztrátumfogyás szabályozottságának fiziológiás glutaminsav-tartományon van biológiai jelentősége, amely citoszolban $40 \mathrm{mM}$, sztrómában $26 \mathrm{mM}$ körül alakul [97]. Nagy felbontásban megvizsgáltuk a 0-30 mM-ig a glutaminsav kinetikát nyers és tisztított kivonattal. Mivel ezeknél a méréseknél a görbe végéröl nem kapunk 


\section{Eredmények}

információt, ezekre a pontokra nem végezhető korrekt nem-lineáris illesztés, illetve linearizálással sem számolhatók helyesen kinetikai paraméterek.

Nyers enzimkivonattal végzett számos vizsgálatunk során ismételhető töréspontokat kaptunk ugyanazon három glutaminsav koncentrációnál (14b ábra). Bár ezek a töréspontok nem minden kísérletben nyilvánultak meg élesen, annak valószínüsége kizárható, hogy ezeket a töréspontokat mérési hiba eredményezi, viszont a GS1 és más GMH-t termelö enzimek jelenléte zavarhatja a mérést nyers enzimkivonatokban.
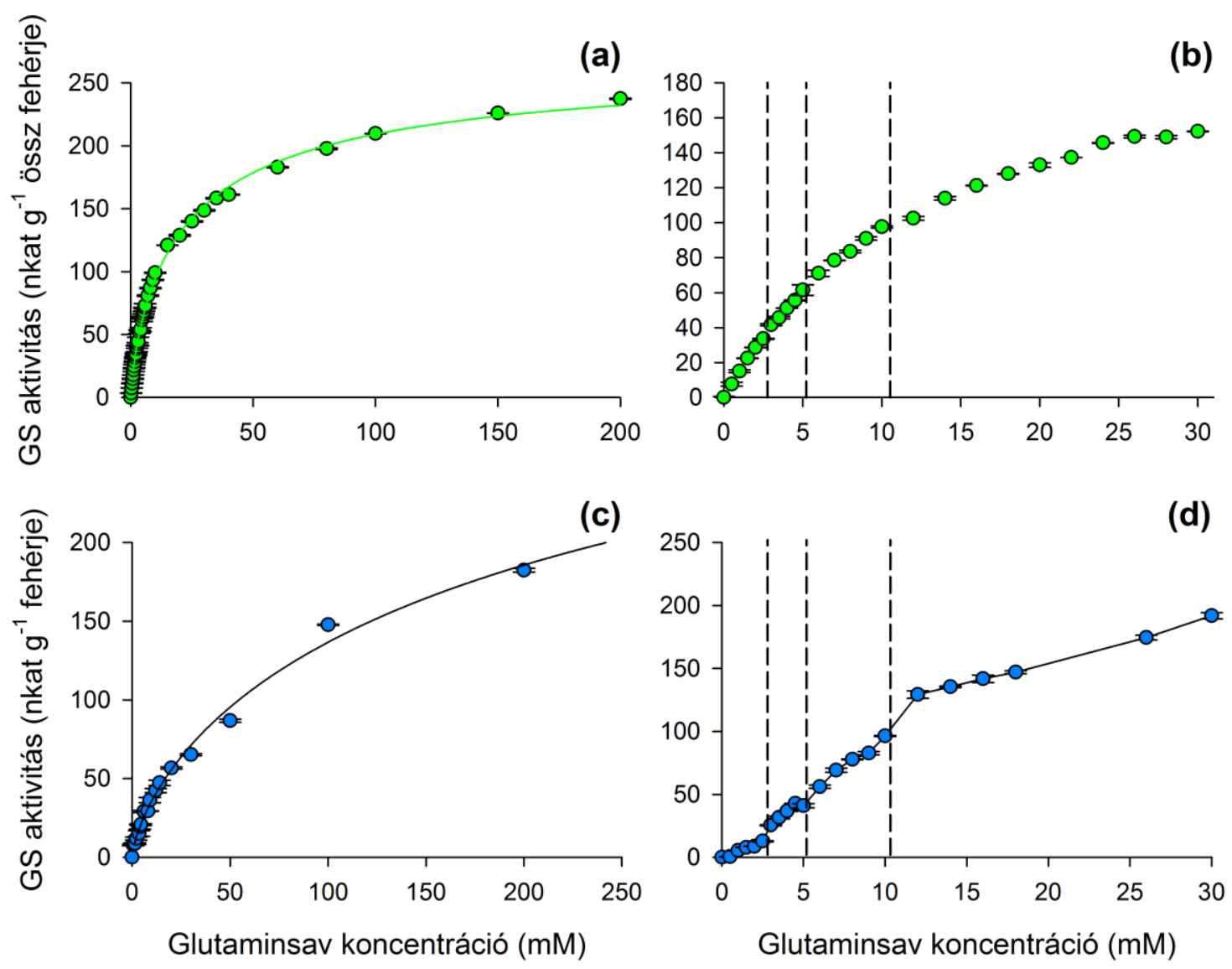

14. ábra: A GS aktivitásának vizsgálata glutaminsav koncentráció soron.

(a-b) Nyers és (c-d) tisztított kivonattal végzett kísérletek, $(a, c)$ fiziológiás feletti és $(\mathrm{b}, \mathrm{d})$ fiziológiás glutaminsav koncentráció tartományig. A függőleges szaggatott vonalak a független kísérletekben ismételhető töréspontok helyét jelölik.

A kísérleteket elvégeztük tisztított kivonattal, melyben a fent említett hátteret adó elemek már nincsenek jelen (14cd ábra). A görbén 3 egyértelmü töréspont látszik, mely a görbét négy részre osztja. Mindhárom töréspont ugyanazoknál a glutaminsav-koncentráció értékeknél jelent meg, mint amit korábban nyers 
kivonatoknál kaptunk (14d ábra). Ezek a töréspontok, melyek egyértelmüen csak a glutaminsav és nem más szubsztrátumok esetében jelentek meg, az enzim müködési sajátosságaiból erednek. Ennek értelmében a görbe négy szakasza 4 katalitikusan aktív hely meglétére utalhat.

Mindazonáltal a tisztított kivonat a GS2-n kívül kis mennyiségben más fehérjéket is tartalmazott (VI. melléklet). Emiatt szükségessé vált esetleges kis molekulasúlyú effektorok keresése.

\subsubsection{Végtermékek hatásának vizsgálata}

Prokariótákban megfigyelték, hogy egyes nitrogénanyagcsere-termékek gátló hatással vannak a glutamintermelésre [148,149]. Annak érdekében, hogy a végtermék gátló hatását kizárjuk megvizsgáltuk a GMH, mint mesterséges és a glutamin mint természetes végtermékek hatását az enzim aktivitásra.

\subsubsection{A GMH hatásának vizsgálata}

Elsősorban azt vizsgáltuk, hogy a reakcióelegyünkben az enzim müködése következtében termelt GMH mint végtermék fejt-e ki gátló hatást az enzimmüködésre, ad-e valamilyen háttérzajt (15. ábra). Az in vitro bioszintetikus reakció során az általunk alkalmazott módszer esetében 10-100 nmol GMH keletkezik a vizsgálati idő alatt.

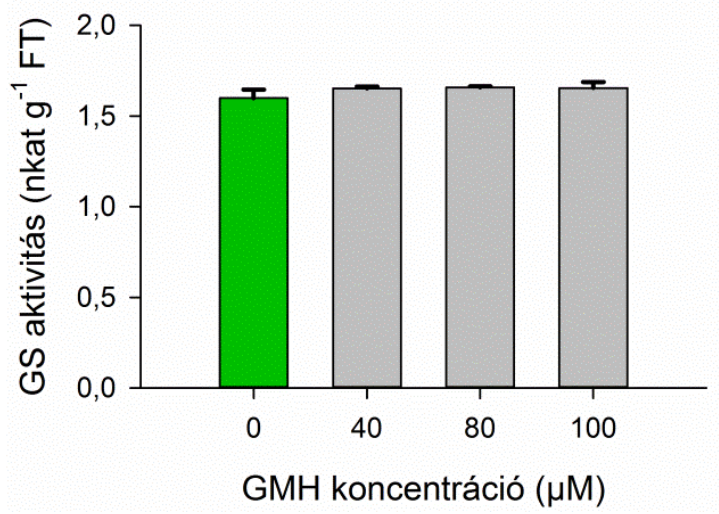

15. ábra: A GMH hatása in vitro a búza glutamin-szintetáz (GS) össz aktivitására nyers fehérje kivonatban.

A kezelések közötti különbség a technikai hiba határán van. A GMH a kísérleti körülmények között nincs hatással a GS aktivitásra. 


\section{Eredmények}

Annak érdekében, hogy kétséget kizáróan megállapítsuk, hogy rendszerünkben a GMH nem zavarja a glutamin képződését, a GMH-t $\mu \mathrm{M}$-nyi mennyiségben (10-100 $\mu \mathrm{M})$ adtuk a reakcióelegyhez.

A kapott aktivitásértékek közti különbség a technikai hibahatáron mozog, amely változások nem állnak korrelációban a GMH-ellátottsággal, mint az várható volna végtermék gátlás esetén. A GMH nincs sem gátló sem serkentő hatással a GS aktivitására. Ez alapján nincs okunk feltételezni, hogy a GMH jelenléte befolyásolná a kinetikai vizsgálataink eredményét.

\subsubsection{A glutamin hatásának vizsgálata}

A GS által katalizált bioszintetikus reakció in vivo végterméke a glutamin. A glutamin hatását glutaminsav-koncentrációsoron vizsgáltuk meg, in vitro. A glutamin a floémben az egyik nagy mennyiségben szállított aminosav [15,100]. A floém aktív feltöltésének következtében az ott szállított anyagok nagy koncentrációban vannak jelen. A korábbi irodalmi adatok alapján, a fiziológiás tartomány fölött, 14 és 57 mM-os glutaminkoncentrációkat választottunk a hatásvizsgálathoz, szembeötlőbb különbségeket várva (16. ábra).

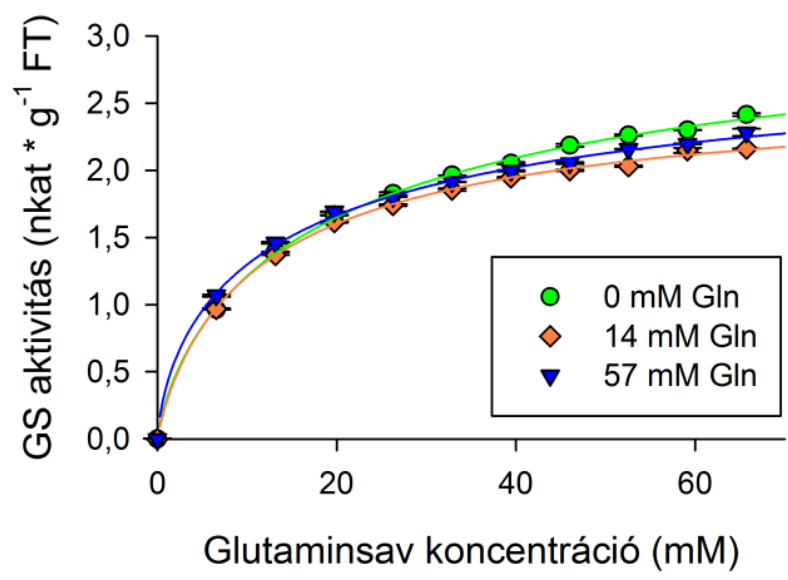

16. ábra: A glutamin hatása a búza glutamin-szintetáz aktivitására nyers kivonatban.

A glutaminsav drasztikus változást nem okozott. A kismértékü változások nincsenek korrelációban a hozzáadott glutaminsav mennyiségével. A mérési sorokra a Hill-egyenlet függvényét illesztettük.

Várakozásainktól eltérően nem tapasztaltunk drasztikus különbségeket a kontroll és kezelt minták között. A hozzáadott glutamint nem tartalmazó minták kinetikai görbéjéhez képest az extra glutaminnal ellátott sorozatok görbéje kissé eltér. 


\section{Eredmények}

Ez az eltérés nem korrelál a glutamin mennyiségével. A kapott differencia magyarázható a nyers enzimkivonatban jelen lévő glutamin- és glutaminsavmetabolizáló enzimek érintettségével. Mérési sorra a Hill-egyenlet függvénye illeszkedett legpontosabban.

Összességében tehát in vitro körülmények között sem emelt GMH, sem magas glutaminkoncentráció esetén nem figyeltünk meg végtermékgátlást.

\subsubsection{Kis molekulasúlyú allosztérikus effektor jelenlétének vizsgálata}

Az in vivo környezetben fellépő makromolekuláris zsúfoltság hatására olyan fehérje-fehérje kölcsönhatások, fehérje-effektor kapcsolatok alakulhatnak ki a sejten belüli terekben, melyek kivonatokban már esetleg nem lesznek jellemzők. Az enzimekhez kötődhetnek olyan kis molekulasúlyú, allosztérikus hatású vegyületek az intakt sejtben, melyek kötődése natív PAGE elválasztással nem kimutatható. A fehérjekörnyezet megváltoztatásával tehát aktivitás vizsgálaton keresztül kimutathatjuk egy allosztérikus hatású molekula hatását, vagy épp cáfolhatjuk, hogy rendszerünkben jelen lenne ilyen hatás. Kísérleteinkben hígítással, albumin hozzáadásával és a kémhatás drasztikus változtatásával próbáltuk megváltoztatni kivonatunkban a fehérjekörnyezetet.

\subsubsection{A hígulás hatása az enzim aktivitására}

Egy esetleges effektor, vagy magának a több alegységes enzimnek a disszociációja, kiváltható a rendszer hígításával. Ez a disszociáció a hígítással arányos enzimaktivitás-csökkenés elméleti lineáris korrelációját megváltoztatja. Méréseink során a kivonatban lévő makromolekuláris zsúfoltság megtartását megfelelő mennyiségü albumint tartalmazó kivonó puffer hozzáadásával biztosítottuk. A fehérjetartalom így konstans a hígított kivonatokban, ezzel kompenzáltuk a pufferrel való hígítással járó fehérje hígulást. Az albuminnal kezelt és kezeletlen minták aktivitását vetettük össze, többféle szempont szerint.

A korábban elvégzett glutaminsav kinetikai méréseket megismételtük teljes kivonaton és annak ötszörös hígításával albumin hozzáadása nélkül és albumin hozzáadásával. Megvizsgáltuk, hogy a teljes kivonatban a korábbiakban észlelt töréspontok változatlanok maradnak-e. A vizsgálatnak korlátot szab, hogy alacsony 


\section{Eredmények}

szubsztrátum-ellátottságnál csak kis mennyiségü termék jön létre, ezért nagyobb hígításnál már nem tanulmányoztuk a reakciósort, hogy a detektálhatóságon belül maradjon a termékképződés. Bár a reakcióidő emelésével ez bizonyos mértékig kiküszöbölhető lenne, ez mégsem szerencsés, mivel proteázgátló használata mellett is számítani kell a fehérje bomlására a tisztítatlan kivonatban.

Összességében azt az eredményt kaptuk, hogy bár nagyobb telítési koncentráción a $V_{\max }$ értékek kis mértékben megemelkedtek, a korábban tapasztalt koncentrációfüggő glutaminsav-fogyasztás dinamikája nem változott egyértelműen kimutatható mértékben. Az eredményeket a 17. ábra szemlélteti. Az ábrához tartozó, a görbeillesztésből származó kinetikai paraméterek az VII. mellékletben megtekinthetők.

(a)

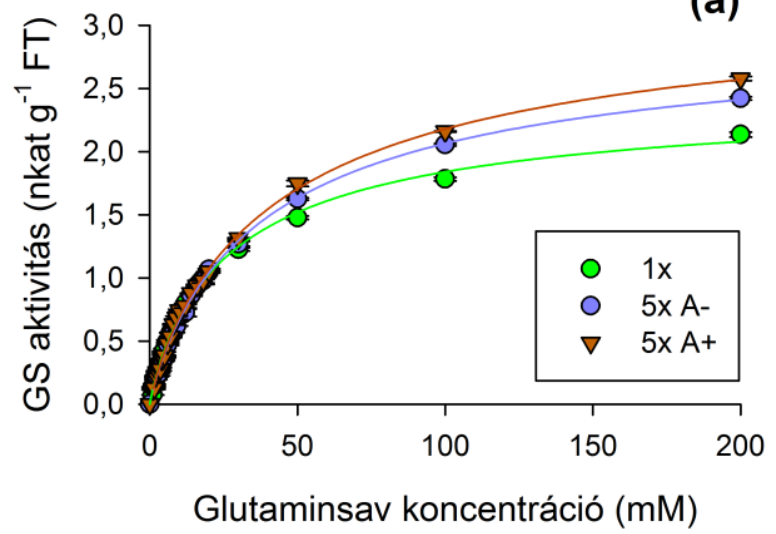

(b)

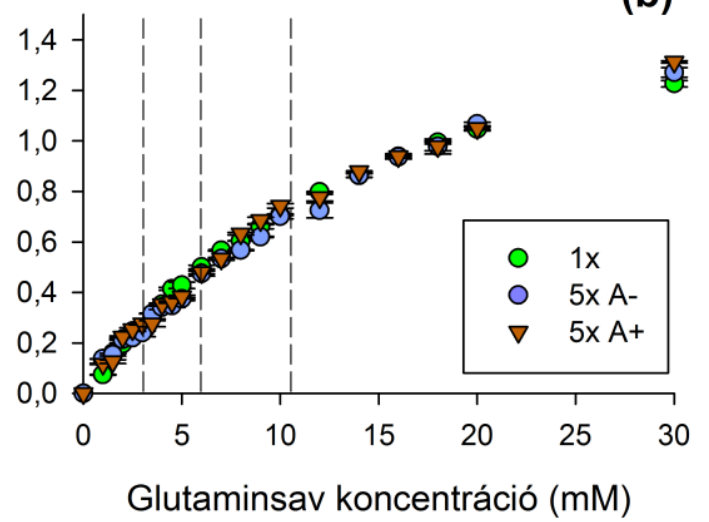

17. ábra: A glutamin-szintetáz glutaminsav függő szubsztrátum-fogyasztásának dinamikája.

(a) A kivonat vizsgálata 0-200 mM glutaminsav-koncentráción. (b) Az (a) ábrán bemutatott görbe $0-30 \mathrm{mM}$ glutaminsav-koncentráció tartományban. A függőleges szaggatott vonalak a kontroll minta esetében megjelenő töréspontokat jelzik. 1x: teljes kivonat, 5x A-: a teljes kivonat 5-szörös hígítása kivonó pufferrel, 5x A+: a teljes kivonat 5-szörös hígatása albumint tartalmazó kivonó pufferrel.

Bár alacsony szubsztrátumkoncentráción a szubsztrátumfogyasztás dinamikájában nem találtunk eltéréseket, a $V_{\max }$ értékek enyhe eltérése miatt a teljes kivonat aktivitását telítési koncentráción, több hígításban is megvizsgáltuk. Célunk elsősorban a saját kísérleti rendszerünkben jelenlévő hatások felderítése volt.

Albumint nem tartalmazó (A-) és az albuminnal kiegészített $(A+)$ minták hígítási sorának enzimaktivitását hasonlítottuk össze (18. ábra). A minta maga a nyers enzimkivonat volt, hiszen bármely tisztítási procedúrán átesett enzim már a tisztítás 


\section{Eredmények}

során hígulásnak van kitéve. Az A- minták hígítási sorozata az enzim aktivitás és a hígítás között lineáris korrelációt mutatott. Az A+ minták esetében ez a linearitás jellemzően csökken, ami a csökkent $\mathrm{R}^{2}$ értékben is megmutatkozik, melyeket a alább18. ábraábrán tüntettem fel.

Az A+ minták aktivitásából adódó görbe a kontroll minták fölé húzódó enyhe konvex görbületet mutat. Ez biokémiai megközelítésben azt jelentheti , hogy az albumin hatással van a rendszerben lévő olyan kölcsönhatásokra, amelyek befolyásolják az enzimműködést. Ezekből az adatokból nem tudjuk megbízhatóan meghatározni a jelenség kémiai hátterét, de nyitva marad a lehetősége annak, hogy bár az általunk alkalmazott reakciókörülmények között (albumin nélkül) effektor hatás nem érvényesül, in vivo környezetben még lehetséges, hogy valamely vagy akár mindkét GS izoenzimhez effektor molekula kapcsolódik.

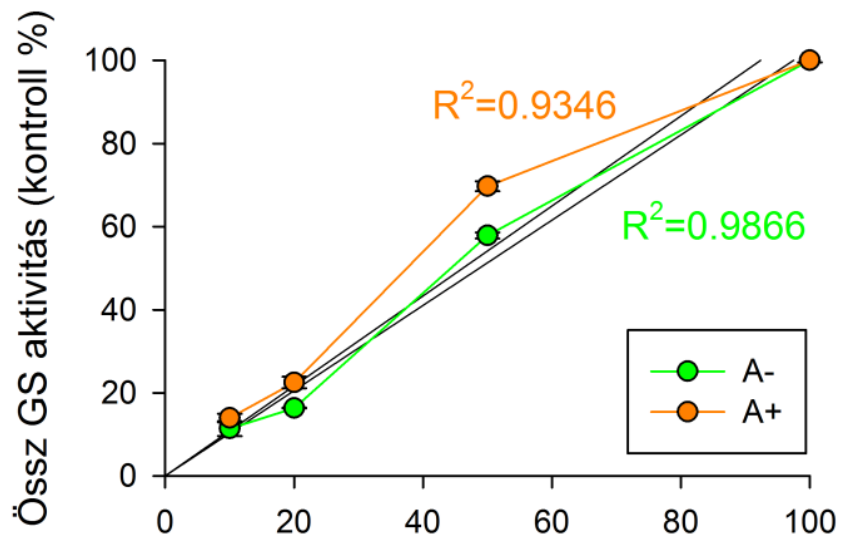

Fehérje tartalom (kontroll \%)

18. ábra: Az aktivitás és fehérje tartalom korrelációjának változása hígítás hatására.

Reakciók albumin hozzáadása nélkül (A-) és albuminnal $(\mathrm{A}+)$. Albuminnal hozzáadásával a lineáris korreláció gyengül, melyet a feltüntetett csökkenő $\mathrm{R}^{2}$ érték mutat.

\subsubsection{A pH hatása az enzim aktivitására}

Az enzimfehérjék felszínén lévő aminósavak, peptid fragmensek oldalláncai meghatározzák annak felületi töltését. Az eltérö kémhatású közegekben ezek az oldalláncok protonálódhatnak, vagy deprotonálódhatnak attól függően, milyen környezetbe kerülnek. Az ionikus környezet megváltoztatásával tehát hatást 


\section{Eredmények}

gyakorolhatunk a fehérje felületi töltésének megváltozására, amely hipotetikusan enyhe szerkezetváltozásokat is okozhat.

Gyenge másodlagos kölcsönhatással kapcsolódó molekulák a felületi töltés megváltozásának eredményeképpen fellépő enyhe szerkezetváltozások hatására, vagy saját de/protonálódásuk eredménye képpen disszociálhatnak az enzim felszínéről.

A kémhatás megváltoztatásával esősorban azt vizsgáltuk, hogy az egyes kinetikai görbék azonos glutaminsav-koncentrációhoz tartozó pontjai, arányukban pontonként jelentős szórással térnek-e el. Ez egyértelműen jelzi, hogy a görbéket leíró függvények egymás y-tengely menti szorzatai-e. Ebben az esetben a görbék dinamikája nem tér el, vagyis az aktivitás változása nem okozza a glutaminsavfüggő lépcsőzetes kinetika megváltozását, vagyis ez az allosztérikus működés változatlan marad. Eredményeinket az 19. ábra mutatja.

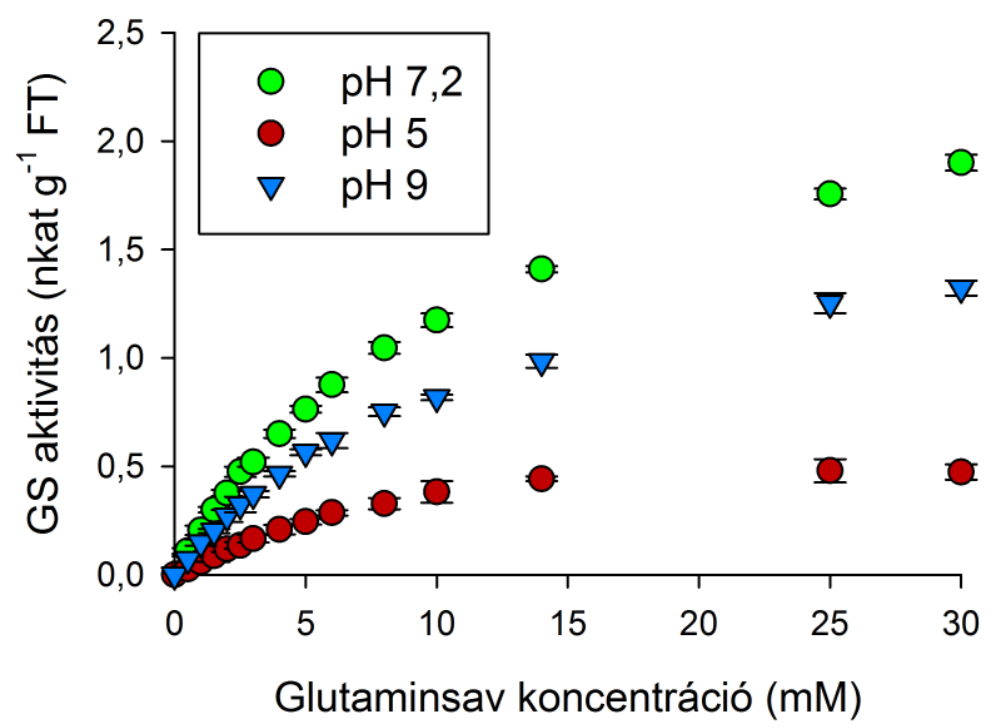

19. ábra: A pH hatása a glutamin-szintetáz enzim aktivitás változására.

Mind savanyúbb, mind alkalikus reakciókörülmények között csökkent az aktivitás.

Az aktivitás a várt módon az optimális $\mathrm{pH}$ 7,2 kémhatású reakció pufferben volt a legmagasabb, pH 5-ösben pedig a legkisebb. Körülbelül dupla akkora aktivitást tapasztaltunk $\mathrm{pH} 9$, mint $\mathrm{pH} 5$ esetében. Mind a $\mathrm{pH} 5$, mind a $\mathrm{pH} 9$ reakciósorok minden pontban arányosak a kontrollal, annak 3,28 $\pm 0,17$ és 1,40 $\pm 0,02$-szorosai. Nincs a mérésekben olyan egyértelmű deviáció, amely arra utalna, hogy a kémhatás megváltozása a glutaminsav függő kinetikus viselkedést befolyásolná. 


\section{Eredmények}

Mérési eredményeink alapján kizárjuk annak valószínüségét, hogy tisztított kivonatunkban a GS2-höz olyan kis effektor molekula kötődne, amely kinetikai vizsgálataink során jelen rendszerben a mérési eredményeket befolyásolhatná. Mindemellett nem zárjuk ki in vivo egy intermolekuláris kapcsolódás lehetőségét.

\subsubsection{Az allosztérikus modell}

A GS2 müködésére eredményeink alapján az allosztérikus negatív kooperativitás és a ,half-site” reaktivitás jellemző. A negatív kooperativitás erős sztérikus tenzió eredménye, mely speciális esetekben „half-site” reaktivitással együtt fordul elő.

A 4 részre osztott glutaminsav kinetikai görbe alapján az enzim 4 katalitikusan aktív egységgel rendelkezik. A „,half-site” reaktivitásnak köszönhetően csak az összes alegység fele aktív. Mivel a katalitikusan aktív egységeket egy-egy alegységpár alkotja, feltételezve, hogy az összes alegységpár müködését észlelhettük, a GS2 összességében oktamer enzim. A gondolatmenetet megfordítva tehát, ha 8 alegységnek csak a fele müködik, akkor 4 különböző $K_{\mathrm{s}}$ értékkel rendelkező alegységpár müködését észlelhetjük a 3 törésponttal 4 részre osztott glutaminsav kinetikai görbén.

Mérési adataink a 4 alegységpár együttes müködéséből származnak. Ez alapján a biokémiai reakció pillanatnyi sebessége 4 függvény összegének az eredménye, mely függvények egyedileg jellemzik az alegységek müködését a következő módon:

$$
v_{0}=v_{a}+v_{b}+v_{c}+v_{d}
$$

Ahol $v_{0}$ az össz aktivitást, $v_{1-4}$ az egyedi alegységeket karakterizáló függvényeket jelöli. Az egyedi függvények a Hill egyenlettel definiálható negatív kooperativitás jellemezhetők. Az egyes katalitikus alegységek egymás után, a glutaminsav koncentráció függvényében válnak aktívvá.

A $K_{s}$ érték nem csak úgy értelmezhető, mint a maximális sebesség feléhez tartozó szubsztrátumkoncentráció, de úgy is definiálható, mint az a szubsztrátumkoncentráció, melynél a katalitikus hely 50\%-os valószínűséggel foglalt. Ennek értelmében több, eltérő szubsztrátumaffinitással rendelkező katalitikus alegység esetén, az $\frac{1}{2} \mathrm{~V}_{\max }-h o z$ tartozó szubsztrátumkoncentráción a szubsztrátumkötődésnek azt a határát érjük el, amelynél az elérhető szubsztrátum 


\section{Eredmények}

50\%-os valószínűséggel kötődik az affinisebb kötőhellyel rendelkező aktív helyen. Minél nagyobb a szubsztrátum koncentrációja, annál nagyobb valószínűséggel lesz foglalt a legnagyobb affinitású kötőhely. Minél nagyobb a valószínüsége annak, hogy az affinisebb kötőhely foglalt, annál nagyobb a valószínűsége annak, hogy az affinitási sorban következő kötőhely is köthet szubsztrátumot, vagyis katalitikusan aktívvá válik. A modellemben ezért a sorban aktiválódó alegységek aktivitását az előző alegység $\mathrm{K}_{\mathrm{s}}$ érték segítségével definiálom. Tehát az x-tengelyen a második alegységet jellemző

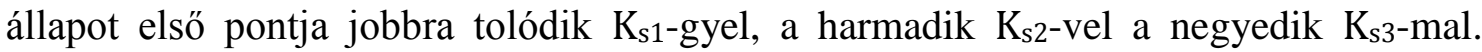
Ekkor:

$v_{0}=\frac{V_{\max 1} \times[S]^{n}}{K_{s 1}^{n}+[S]^{n}}+\frac{V_{\max 2} \times\left[S-K_{s 1}\right]^{n}}{K_{s 2}^{n}+\left[S-K_{S 1}\right]^{n}}+\frac{V_{\max 3} \times\left[S-K_{s 2}\right]^{n}}{K_{s 3}^{n}+\left[S-K_{s 2}\right]^{n}}+\frac{V_{\max 4} \times\left[S-K_{s 3}\right]^{n}}{K_{s 4}^{n}+\left[S-K_{s 3}\right]^{n}}$

Ahol $\mathrm{S}$ az aktuális szubsztrátumkoncentráció, $n$ a Hill koefficiens, $\mathrm{V}_{\max 1-4}$ az aktuális szubsztrátumkoncentráció és $\mathrm{K}_{\mathrm{s} 1-4}$ az alegységekre jellemző $1 / 2 \mathrm{~V}_{\text {max1-4-hoz }}$ tartozó szubsztrátumkoncentráció és $S-K_{s \varepsilon-1}<K_{s \varepsilon}(\varepsilon:[2-4])$ valamint $K s \varepsilon<K s \varepsilon+1$.

A fenti egyenletek tehát felírhatók a következő részletes formában:

$$
v_{0}=\frac{1}{\left(\frac{K_{s 1}}{[S]}\right)^{n}+1}+\frac{1}{\left(\frac{K_{s 2}}{\left[S-K_{s 1}\right]}\right)^{n}+1}+\frac{1}{\left(\frac{K_{S 3}}{\left[S-K_{s 2}\right]}\right)^{n}+1}+\frac{1}{\left(\frac{K_{s 4}}{\left[S-K_{s 3}\right]}\right)^{n}+1}
$$

Ez alapján belátható, hogy az $\mathrm{S}<\mathrm{K}_{\mathrm{s} 1}$ állapotig a $v_{2-4}$, az $\mathrm{S}<\mathrm{K}_{\mathrm{s} 2}$ állapotig a $v_{3-4}$, az $\mathrm{S}<\mathrm{K}_{\mathrm{s} 3}$ állapotig a $v_{4}$ függvény nem értelmezhető, mivel a nevezőbe ekkor 0 kerül. Ezekben az állapotokban ezek nem jelennek meg addícionális tagként. Vagyis ezek az állapotok azt írják le, hogy a soron következő alegység nem köt szubsztrátumot. A modellt a 20a ábra szemlélteti. Az allosztérikus negatív kooperativitás miatt az alapállapotban még egyforma glutaminsav affinitással rendelkező alegységek affinitása megváltozik a szubsztrátum kötésével (20b ábra). Ezt az affinitásbeli különbséget az egyes állapotokhoz tartozó $\mathrm{K}_{\mathrm{s}}$ értékek eltérése mutatja meg.

Megalkottunk egy olyan allosztérikus modellt, amely megmagyarázza a töréspontok jelenlétét és számításba veszi az enzimmüködést jellemző, sztérikus taszításból fakadó allosztérikus negatív kooperativitást. A modell nem számol a magasabb glutaminsav koncentrációknál többféle állapot egyidejü megjelenésének 
valószínüségével. A jelenlegi modell feltételezi, hogy egy meghatározott szubsztrátumkoncentráció alatt a soron következő, kisebb affinitású alegység egyáltalán nem válik aktívvá.

(a)

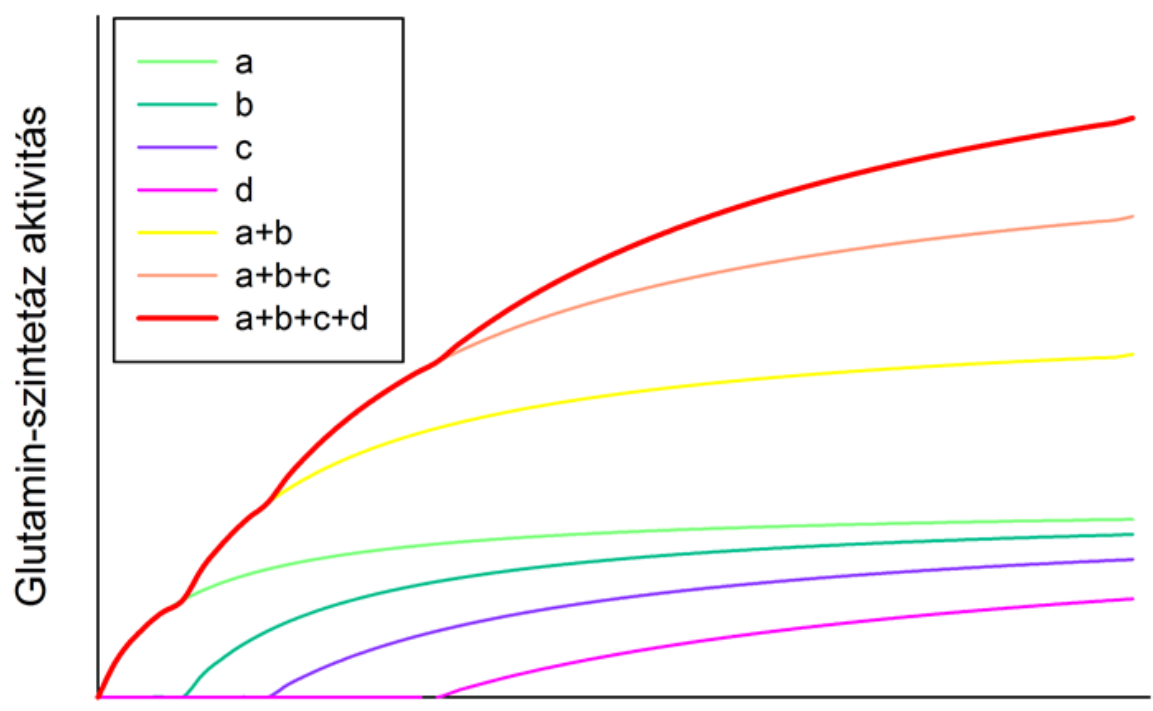

Glutaminsav koncentráció

(b)

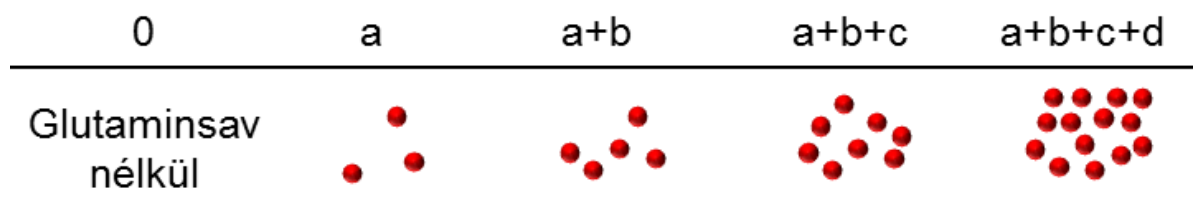

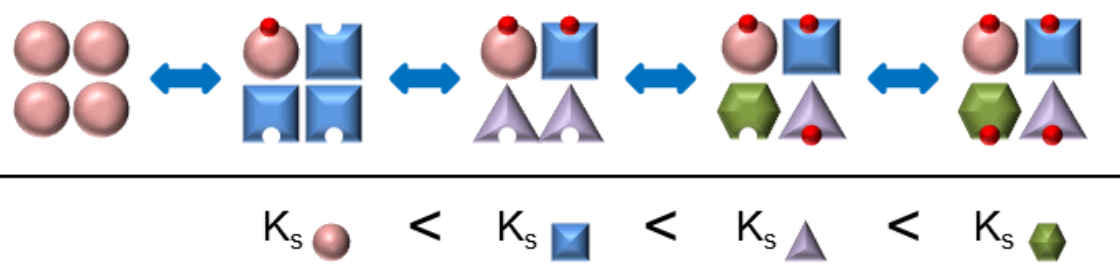

20. ábra: A plasztiszban lokalizált glutamin-szintetáz enzimmüködésének modellje.

(a) az enzim aktivitást karakterizáló függvények és összegzésük ábrázolása. Az a-d függvények külön szemléltetik az egyes alegységek aktiválódását, az összegfüggvények szemléltetik az egy időben dolgozó függvények aktivitását. A pirossal jelölt függvény jelöli a 4 katalitikus hely össz aktivitását, a mérhető GS aktivitást. (b) A glutaminsav (piros körök) kötődésének hatása a katalitikus helyek affinitására, különböző glutaminsav ellátottság alatt, az (a) ábra függvényeihez tartozó állapotok vizualizációja. Az eltérő geometriai formák az aktív alegységpárok lehetséges állapotváltozásait illusztrálják. 


\section{Eredmények}

\subsection{Fémionok hatásának vizsgálata}

Vizsgálataink elsődleges célja volt, hogy megvizsgáljuk, megváltoztatják-e jelentős mértékben a különböző fémionok a GS allosztérikus viselkedését, alapjában változnak-e a kinetikai görbék. Tanulmányoztuk, milyen hatással van egy aktivitást serkentő, valamint egy aktivitást gátló fémion jelenléte a GS aktivitására.

\subsubsection{Magnézium telítődés vizsgálata}

A magnézium esszenciális a GS müködéséhez. Elsőként magnézium koncentrációsoron tanulmányoztuk a GS aktivitást, ennek segítségével megállapítottuk további kísérleteinkhez az optimális $\mathrm{Mg}^{2+}$ koncentrációt (21. ábra).

Növekvő magnéziumkoncentrációra állandó szubsztrátumellátottság mellett szigmoid görbét kaptunk nyers fehérjekivonatban. A görbe $12 \mathrm{mM}$ felett telítődik, a szigmoid inflexiós tartománya 5 és $10 \mathrm{mM}$ között van.

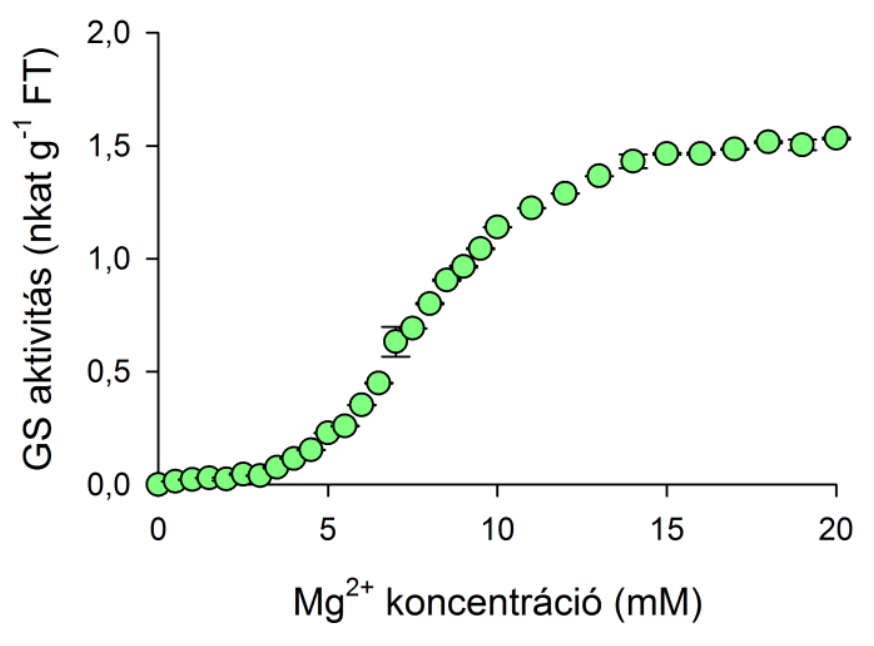

21. ábra: A magnéziumellátottság hatása a GS aktivitásra.

Az aktivitás változása alapján a magnézium-kötőhely telítődésére a szigmoid görbe jellemző.

\subsubsection{Alumínium hatásának vizsgálata}

Ismeretes, hogy az $\mathrm{Al}^{3+}$ közvetlenül kötődik a GS egyik fémion kötőhelyéhez és ez a kötődés aktivitást növelő hatással van az enzim működésére [126]. Megvizsgáltuk, hogy ez a serkentő hatás az allosztérikus működés befolyásolásán keresztül valósul-e meg. 


\section{Eredmények}

Azt az eredményt kaptuk (22. ábra), hogy a kontroll állapothoz képest a görbe minden glutaminsav-koncentrációban a kontroll állapot állandószoros $(1,55 \pm 0,04)$ szorzata. A görbe dimenziója nem változik, nem tolódik jobbra, vagy balra az X-tengely (glutaminsav-koncentráció) mentén.

Eredményeink alapján tehát $\mathrm{az} \mathrm{Al}^{3+}$ a nélkül befolyásolja a reakció sebességét, hogy a glutaminsav-kötőhelyek affinitását változtatná.

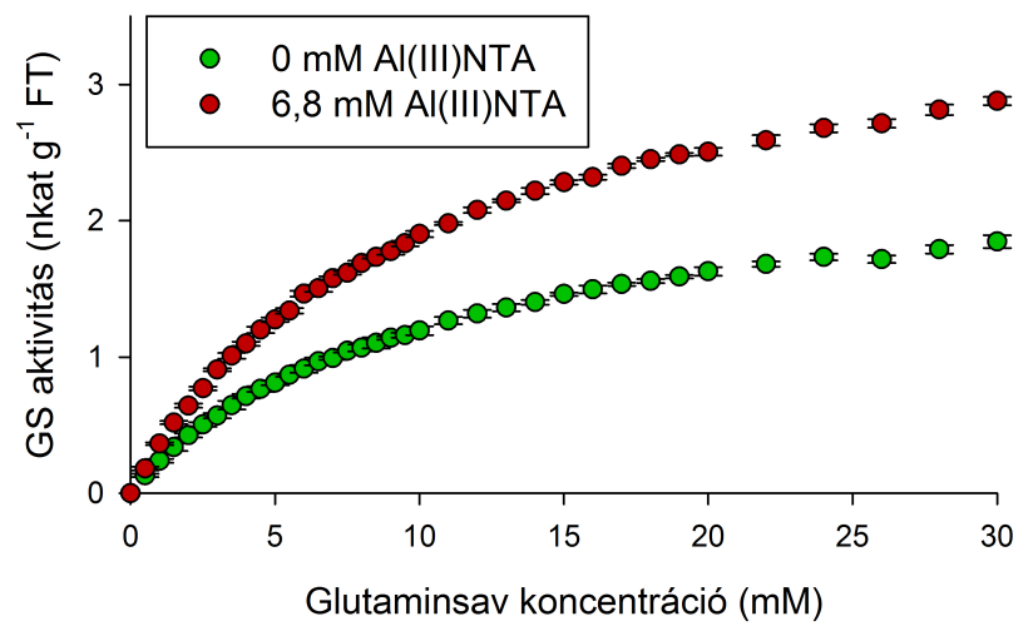

22. ábra: A glutamin-szintetáz aktivitásának változása alumínium-nitrilotriecetsav hatására in vitro.

$\mathrm{Az} \mathrm{Al}^{3+}$ fémion jelenlétének hatására nő az enzim aktivitása, de a kezelt enzim müködését leíró görbe oldal irányú eltolódása nem figyelhető meg. Al(III)NTA: alumínium-nitrilotriecetsav.

\subsubsection{Mangán hatásának vizsgálata}

A transzferáz aktivitást mérő protokollok használnak mangántartalmú vegyületet az in vitro enzimreakcióhoz [9]. A búza össz GS aktivitására viszont egyértelműen gátló hatással van a mangán jelenléte a reakcióelegyben a bioszintetikus reakcióban.

Kísérleteinkben $\mathrm{MnCl}_{2}$ és $\mathrm{MnSO}_{4}$ hatását is megvizsgáltuk (23b ábra). A vizsgált mangán sók hatására azonos gátló hatást kaptuk. Ennek értelmében a kísérletben használt mangánsók disszociációja során felszabaduló $\mathrm{Cl}^{-}$és $\mathrm{SO}_{4}^{2-}$ ionok eltérő aránya nem eredményez eltérő kimenetelt. A kísérleteket ezért a továbbiakban $\mathrm{MnCl}_{2}$-dal folytattuk (23b ábra). Rendkívül alacsony, 167,3 \pm 1,0 nM koncentrációnál már 50\%-os gátlást tapasztaltunk. 
(a)

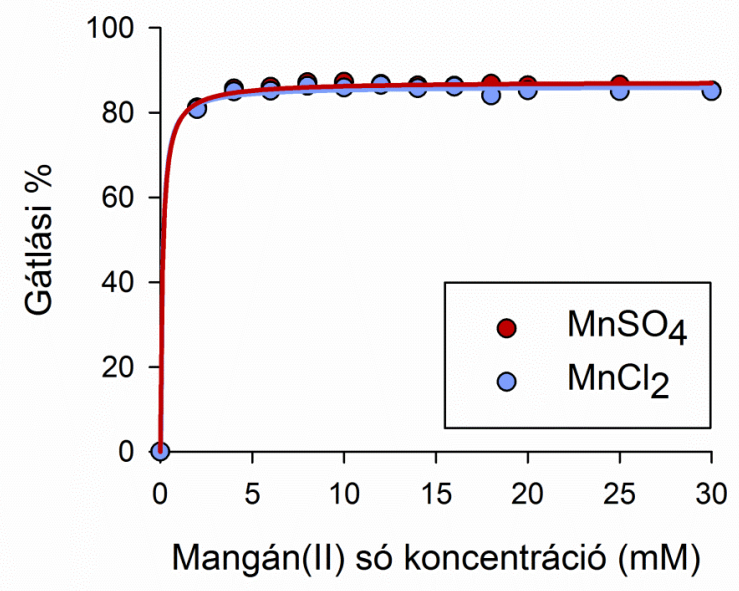

(b)

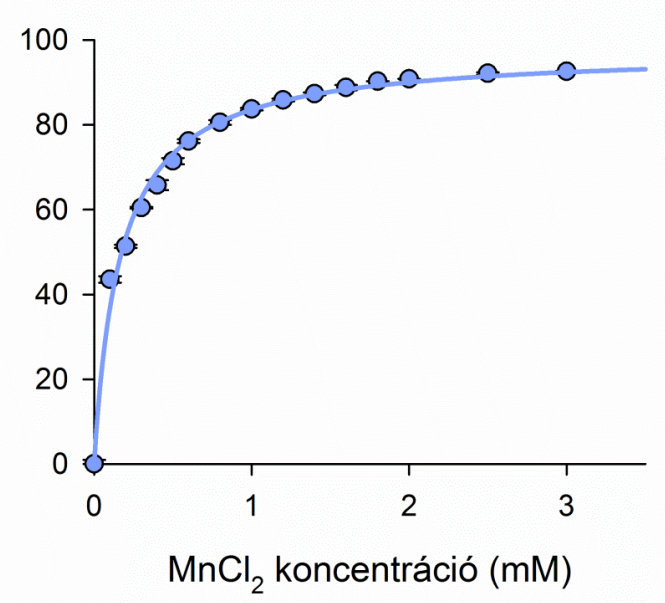

23. ábra: $\mathrm{A} \mathrm{Mn}^{2+}$ gátló hatása a glutamin-szintetáz aktivitására in vitro.

(a) A sóból felszabaduló negatív töltésủ ionok nincsenek hatással a reakcióra, vagy a hatás azonos mértékü. (b) A gátlás teljes kivonatban már $\mu \mathrm{M}$-os koncentrációban érvényesül.

Megvizsgáltuk, hogy a mangán jelenléte hatással van-e a glutaminsav-fogyasztás koncentrációfüggő dinamikájára, az alumínium esetében alkalmazott logika szerint. 0,2 $\mathrm{mM} \mathrm{MnCl}_{2}$-kezelésre az aktivitás a felére $(0,518 \pm 0,054$-szeresére $)$, 0,4 mM MnCl 2 -kezelésre a harmadára $(0,365 \pm 0,038$-szeresére $)$ esett vissza. A mangánkezelt mérési sor minden pontja a kontroll állapot azonos glutaminsavkoncentrációnál mért érték hányadosa. Vagyis a görbe nem tolódik el az X-tengely (glutaminsav koncentráció) mentén (24.ábra).

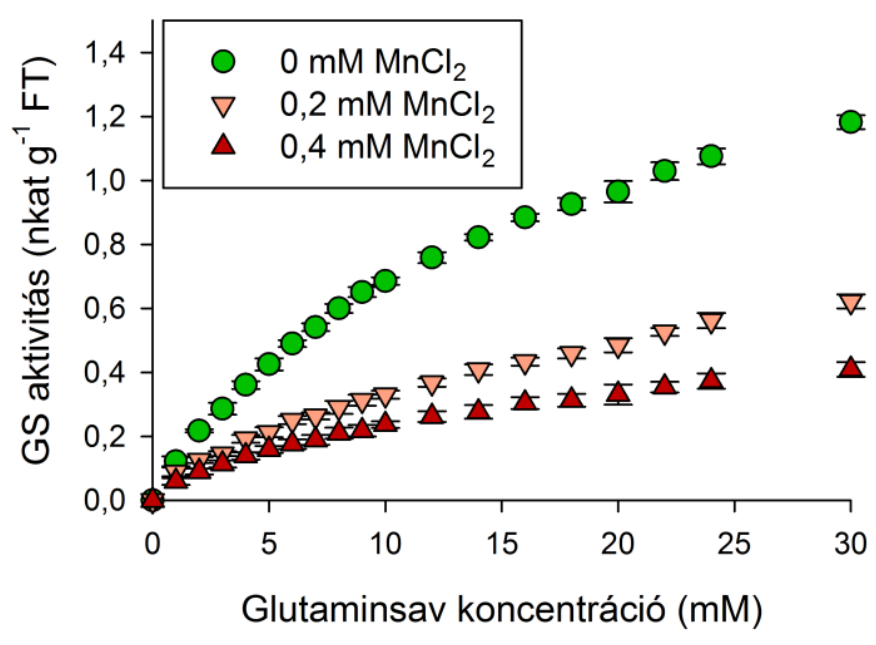

24. ábra: A glutamin-szintetáz aktivitása $\mathrm{Mn}^{2+}$-kezelés hatására.

A GS enzim aktivitása mangán hiányában, valamint 0,2 és $0,4 \mathrm{mM} \mathrm{MnCl}_{2}$-dal történő in vitro kezelés hatására. 


\section{Eredmények}

Tehát a mangán kötődése befolyásolja a reakciósebességet, de feltehetőleg nem befolyásolja a glutaminsav-telítődés dinamikáját. Mindemellett a képződő GMH sincs hatással az enzimaktivitására mangán jelenlétében sem, mivel a görbe nem laposodik el.

$\mathrm{A} \mathrm{Mn}^{2+}$ hatását az enzim bivalens kation kötőhelyeire natív PAGE és ICP-MS kombinációjával vizsgáltuk. $\mathrm{Mn}^{2+}$ és $\mathrm{Mg}^{2+}$ jelenlétében 20 percig hagytuk futni a biokémiai reakciót, majd az elegyeket natív gélre vittük. Elválasztás után a gél egy szeletén végrehajtott aktivitás vizsgálat segítségével feltérképeztük az izoenzimek pontos helyét. A GS2 sávját izoláltuk, és ICP-MS vizsgálatra küldtük. A mérésből kapott eredményeket a 25. ábra mutatja be.

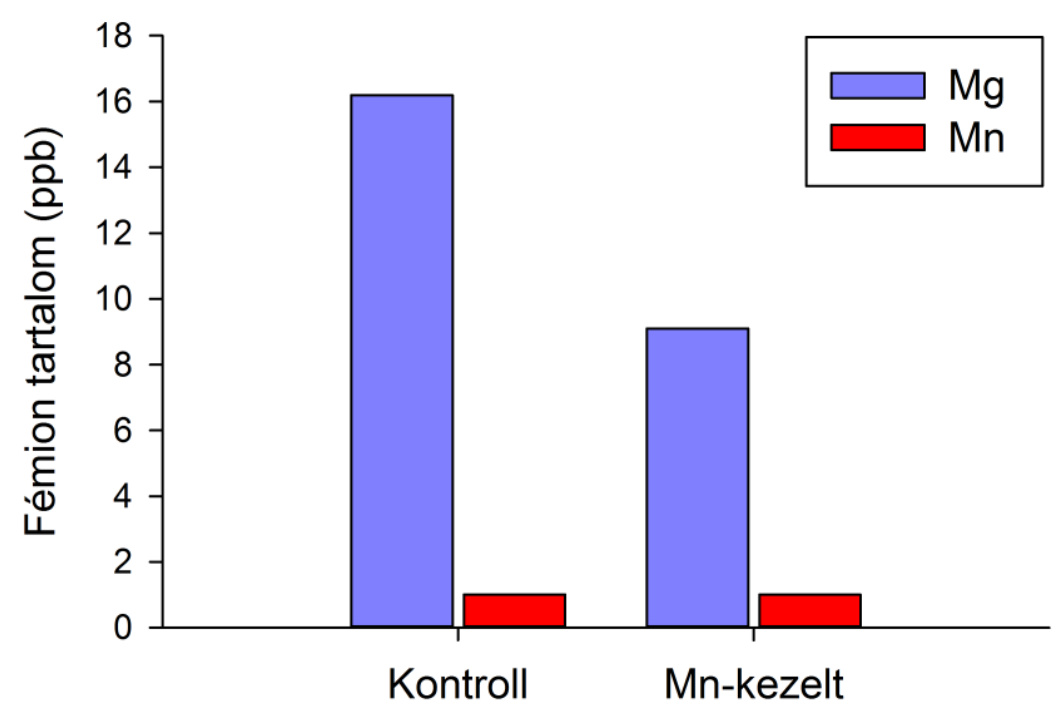

25. ábra: A kloroplasztiszban lokalizált glutamin-szintetáz fémion tartalmának változása in vitro $\mathrm{Mn}^{2+}$ kezelés hatására.

A GS2 magnéziumtartalma $\mathrm{Mn}^{2+}$ kezelés hatására a felére csökkent. A minták $\mathrm{Mn}^{2+}$-tartalma a kvantitálási határon van, különbséget nem tudtunk kimutatni.

Kontroll állapotban a magnézium stabilan kötődik az enzimhez, a mangán kezelt mintából származó GS-ben viszont a $\mathrm{Mg}^{2+}$ mennyisége a felére esett vissza. Mindkét minta esetén $1 \mathrm{ppb} \mathrm{Mn}^{2+}$-tartalmat eredményező jelet kaptunk. Ez a mennyiség az ICP-MS mérés kvantitálási határán van, tekinthetjük a mangán mérés háttérzajának. $\mathrm{A} \mathrm{Mn}^{2+}$ nem volt jelen egyértelműen detektálható mennyiségben egyik vizsgált szegmensben sem. Feltételezzük, hogy a $\mathrm{Mn}^{2+}$ az elválasztás során disszociál a fehérjéről, ahhoz csak gyengén kötődik. $\mathrm{A} \mathrm{Mg}^{2+}$ és $\mathrm{Mn}^{2+}$ közti különbséget az $\mathrm{n} 1$ és n2 kötőhelyek különbözősége magyarázhatja. 


\section{Eredmények értékelése}

\subsection{Az enzim alegység-összetételének vizsgálata}

A búzalevél GS izoenzimek alegység-összetételének homomeritását egy speciális kétdimenziós elválasztást követően protein blottal vizsgáltuk (11. ábra). A vizsgálathoz a kétdimenziós szeparálás első dimenziója natív gélelektroforézis volt, amely során a citoplazma és kloroplasztisz lokalizált izoformák natív gélen jól elkülöníthetően elváltak egymástól. Az izoenzimek ilyen módon való elválasztása, és annak hatékonysága mühelyünk korábbi közleményeiböl már ismert [12,126]. A korábbi kísérleti eredményeknek megfelelően csak 1-1 sávot kaptunk, a GS1-re, illetve a GS2-re. A második dimenzióban SDS-PAGE-et alkalmaztunk. Blottolás után a GS1 és GS2 izoenzimeket két elkülönülő folt jelölte, az izoenzimekre jellemzö molekulasúly tartományban. Az izoenzimeket tehát egyrészt azonos alegységek építik fel, másrészt nincs az alegységekhez kötve olyan molekula, amely az enzim felszíni töltését vagy molekulatömegét megváltoztatja az alkalmazott módszerek érzékenységi tartományán felül.

Eredményem ellentmondásban áll egy olyan közlemény álláspontjával, mely egy harmadik GS izoforma jelenlétét taglalja más búzafajtákban [150]. A publikációban alkalmazott mintakezelés eltér az általunk alkalmazottól, és nem veszi figyelembe a spontán degradáció lehetöségét. Emellett a hexamer alegység összetételt feltételezi, de nem veszi tekintetbe az eredmények kiértékelésekor, hogy a GS egy rendkívül kompakt multimer enzim, nagyon kevés rendezetlen régióval. Ismert, hogy a kromatográfiás eljárásokban a molekula alakja is befolyásolja annak mobilitását. Ahogyan ez előnyként kihasználható racém elegyek elválasztásánál, úgy jelenthet ez problémát a fehérjék elválasztása során. A „blue” natív elektroforetikus elválasztás során a GS holomer molekulatömegéhez képest emiatt nagyobb elektroforetikus mobilitással is rendelkezhet, mint a cikkben referenciaként alkalmazott fehérjék, melynek nem is jelölték meg az identitását. A GS3-ként azonosított fehérje szekvenciája pedig aminosavra azonos az ismert GS2-vel, de azon a poszttranszlációs módosítási helyeket máshol jelölték meg. A kutatócsoport által alkalmazott LC-MS elválasztás ugyan alkalmas információ gyüjtésére, de azok megbízhatósága kicsi. Az izoenzimet pedig fény által szabályozott folyamatokra megjelenő izoformaként emlegették. Az egyhetes 
növényekből többéves munkám során sohasem sikerült ilyen izoenzimet izolálnom. Annak lehetőségét elvetem, hogy a rendszerünkben ilyen izoforma jelen lenne.

A szakirodalomban eddig szerkezetileg leírt GS izoformákat homomer összetételüként jellemezték, eredményeink is ezt az álláspontot erősítik meg. Az alegységösszetétel heterogenitásának, vagyis a homomer szerkezetnek az ismerete modellezési szempontból igen fontos, hiszen részben ez adhatja alapját annak a feltételezésnek, hogy minden aktív hely müködése ugyanazzal az alap függvénnyel írható le.

\subsection{Kis molekulasúlyú effektor jelenlétének vizsgálata}

Az enzim alegység-összetételének vizsgálata során nem zárhattuk ki annak a lehetőségét, hogy mialatt a mintákat előkészítettük az elektroforetikus vizsgálatokra, ne veszíthettünk volna el egy esetleges lazán kötődő effektormolekulát. A különböző fehérje- és sókoncentrációjú kompartmentumok már a kivonat elkészítésekor, a minta homogenizálása során hatással vannak a fehérjekörnyezetre. Emellett a fehérjék kiemelése azok natív makromolekuláris környezetéböl szintén megváltoztathatja egymáshoz való viszonyukat. Az intracelluláris környezetre jellemző makromolekuláris zsúfoltság egészen más kölcsönhatásokat képes fenntartani, mint amiket in vitro megfigyelhetünk. Már a minta homogenizálásakor a vakuoláris és apoplasztikus szférában jelenlévő jelentős mennyiségü víz felszabadítása is hígítja az in vivo környezetet.

Lúdfüben mutatták ki az ACR11 fehérje kölcsönhatását a GS-zal. Az ACR11 in vitro kísérletekben megváltoztatta a $\mathrm{GS} \mathrm{K}_{\mathrm{s}}$ értékét a $\mathrm{V}_{\max }$ érték megváltozása nélkül. Vizsgálatainknak nem volt célja egy ilyen kölcsönható partner azonosítása, de ki kellett zárnunk annak a lehetőségét, hogy tisztított kivonatban jelen vannak az enzim müködését befolyásoló egyéb komponensek.

Egy effektor jelen lehet a nyers kivonatos rendszerekben. Amennyiben egy ilyen rendszer hígítása jelentősen eltér a lineáristól, vagyis egységnyi hígulásra nem arányos változások következnek be az aktivitásban, az utalhat egy effektor jelenlétére, vagy az enzim oligomer destabilizálódására. A rendszerünket hígítással vizsgálva (17. és 18. ábra) nem kaptunk olyan eredményt, amely egyértelműen utalna allosztérikus effektor jelenlétére, vagy a GS multimer disszociációjára. 


\subsection{Szubsztrátumszintű szabályozás vizsgálata}

A szubsztrátumszintű szabályozást számos kinetikai kísérletben vizsgáltuk, melyeket szoftveresen értékeltünk ki. Kísérleteink elsődleges célja nem az enzim részletes biokémiai karakterizálása, hanem a szubsztrátumfogyasztás kinetikai görbéinek dinamikájának vizsgálata, az azokat leíró differenciál egyenletek dimenziójának meghatározása által allosztérikus szabályozás lehetőségének, és regulátor szubsztrátum keresése.

\subsubsection{Végtermékek hatásának vizsgálata}

A biokémiai útvonalak realisztikus kinetikai modellezéséhez nélkülözhetetlen az allosztérikus szabályozás alatt álló enzimek ismerete [151]. Az egyes enzimreakciók végtermékei hatással lehetnek a reakciót katalizáló enzimre, annak müködését pozitívan vagy negatívan befolyásolhatják.

Ismert, hogy a prokariótákban felfedezték egyes aminosavak negatív feedback szabályozó hatását a nitrogén anyagcserében, mely a GS aktivitás gátlásán keresztül valósul meg. A GS-nak 3 féle katalitikus aktivitása ismert. In vivo körülmények között a GS a glutaminsavat glutaminná alakítja. In vitro pedig két eset játszódhat le az alkalmazott reakciókörülményektől függően. Leírták az enzim transzferáz aktivitását, amely egyfajta módosított reverz reakció, melynek eredményeképpen megfelelő reakciókörülmények alkalmazásával, hidroxilamin hozzáadásával GMH jön létre. In vitro rendszerünkben, ami egy módosított, de szintetikus reakció, GMH keletkezik. Nem volt fellelhető olyan szakirodalom, mely a GMH termékgátlását taglalta volna. Mivel a szakirodalomban a negatív eredmények ritkán leközöltek, bizonytalan volt, hogy a termékgátlás tényleges hiánya vagy a negatív eredmények nehézkes publikálhatósága miatt nincs a GMH, mint termék hatásáról információnk. Megvizsgáltuk tehát in vitro, hogy a módosított reakció során GMH hozzáadásával hatással lehetünk-e a reakciósebességre (15 ábra). A GMH hozzáadása nem okozott ilyen változásokat, a kontroll állapothoz képest. A mesterséges végtermék tehát nem okoz termék gátlást.

A természetes végterméknek, a glutaminnak részletesen megvizsgáltuk a reakcióra kifejtett hatását teljes kivonatban (16. ábra). A glutamin hozzáadása okozott kisebb változásokat a reakciót jellemző kinetikai görbében. A teljes kivonatban viszont 
a glutamin maga extra szubsztrátumként van jelen. Így feltételezhetően befolyásolja például akár a GOGAT müködését, ami extra glutaminsav termelést jelent a reakcióelegyben. Végeredményben nem találtunk arra vonatkozó erős és egyértelmü bizonyítékot, hogy a glutamin negatív feedback regulátor lenne in vitro közegben, a termék gátlást a glutamin esetében is kizárhatjuk.

\subsubsection{Szubsztrátumok hatásának vizsgálata}

Azzal a céllal, hogy regulátor szubsztrátumot találjunk, elvégeztük az egyes szubsztrátumok hatásának részletes analízisét. Erre vonatkozó kísérleteinkben a GS reakciósebességének változásait szubsztrátum-koncentrációsorokon vizsgáltuk.

\subsubsection{A hidroxilamin hatása}

Az enzim aktivitását a GMH Fe(II)-vel savas közegben képzett színes vegyületén keresztül tudjuk detektálni. A GMH képződéséhez, viszont hidroxilaminra van szükség nitrogén donorként. Az enzim aktivitásáról így olyan információt nyerünk, amely hủen tükrözi annak ammónia fogyasztását. Ezért tanulmányozhattuk az ammónia fogyasztás dinamikáját hidroxilamin koncentrációsoron. Ezt a dinamikát több féle glutaminsav ellátottság mellett is megvizsgáltuk (12. ábra).

A kapott hirtelen emelkedő, gyorsan telítődő kinetikai görbe alapján elmondható, hogy a GS rendkívül magas ammónia affinitással rendelkezik, mely állításunkat a kalkulált alacsony $\mathrm{K}_{\mathrm{s}}$ értékek is igazolták. Ez a rendkívüli affinitás önmagában is arra utal, hogy a hidroxilamin-fogyasztásnak nincs semmilyen autoregulációs korlátja.

A glutaminsav-ellátottság növelte a maximális sebességet, és a glutaminsav-ellátottság függvényében a $\mathrm{K}_{\mathrm{s}}$ értékek is rendre növő tendenciát mutattak. Ez alól kivétel az $1 \mathrm{mM}$ glutaminsav-ellátottság alatt mért Ks. Egyrészt a kinetikai görbék helyes felvételezéséhez elengedhetetlen a kezdeti szakaszok felvételezése megfelelően nagy pontsürüséggel. Esetünkben a rendkívül alacsony koncentrációtartományban telítődő görbe miatt meglehetősen nehézkes a $\mathrm{K}_{\mathrm{s}}$ érték meghatározása a reakcióelegy összeméréséből adódó X-irányú szórás, vagyis az esetleges apró diszturbanciák igen nagy jelentősége miatt a kezdeti szakaszon. Másrészt a mérhető aktivitások is meglehetősen alacsonyak. 


\section{Eredmények értékelése}

Bár a glutaminsav hatása a $\mathrm{K}_{\mathrm{s}}$ értékekre igen csekély, nem tudhattuk, hogy a felvételezés nehézségeiből adódik-e ez az eltérés. Ezek az eredmények felvetették annak a lehetőségét, hogy a glutaminsav regulátor szubsztrátum. $\mathrm{A} \mathrm{V}_{\max }$ értékek növekedése lehet egy reguláció következménye. Bár ez az emelkedés lehetne annak a következménye is, hogy a reakciótérben a glutaminsav mennyiségének növelésével megnöveljük a szubsztrátum és az enzim találkozásának, ezzel a szubsztrátumkötés valószínüségét.

Egyértelmü, hogy az ammónia az enzim aktivitásának szubsztrátumként nem regulátora, valamint a stabil telítődés azt is megmutatja, hogy $25 \mathrm{mM}$-os hidroxilamin koncentrációig nem valósul meg olyan spontán amináció, ami zavarná az enzim müködését. Tehát, amennyiben a reakciót tisztított enzimkivonatokon hajtjuk végre, akkor a reakcióelegy ammóniumtartalma nem lesz hatással a tisztított enzim stabilitására, müködésére.

\subsubsection{Az ATP hatásának vizsgálata}

A GS által katalizált reakció lejátszódását az ATP hasítása során felszabaduló energia biztosítja. Az ATP hatását több glutaminsav-koncentráció mellett is megvizsgáltuk (13. ábra). Minden esetben azt tapasztaltuk, hogy a glutaminsavellátottság meghatározza a maximális sebességet. A görbék fiziológiás tartományon sem szigmoid, sem gyökös függvények jellemzőit nem mutatják, ami arra utal, hogy az ATP kötődését nem jellemzi sem pozitív sem negatív allosztérikus kooperativitás.

Ezen felül az ATP kinetikai görbék felfutása mérsékelt a hidroxilamin görbékhez képest. Ez arra utal, hogy az enzim katalitikus ATP kötőhelye kisebb affinitású, mint a hidroxilamin kötőhely. Arról nincs közvetlen információnk, hogy az ATP kötődése szükséges-e a hidroxilamin kötőhely aktivációjához növényi GS-okban.

Az ATP esetében is érvényesek azok a megfigyelések, mint amiket a hidroxilamin kinetikák $\mathrm{K}_{\mathrm{s}}$ értékeinek esetében észleltünk a glutaminsav-ellátottság hatását illetően nyers enzimkivonatban. Bár az ATP nagy koncentrációban csökkenti az aktivitást, a telítődés kinetikai paramétereit a gátlás fellépéséig jellemeztük, mivel feltételeztük, hogy eddig a pontig az ATP esszenciális a reakció lejátszódása szempontjából. Másrészt nem ismert olyan széles körben alkalmazott és elfogadott differenciálegyenlet, amely ilyen típusú gátlást egyértelműen jellemez. 
Az ATP kinetikai görbék maximumukat elérve a plató fázis kitartása helyett növekvő ATP-koncentráció mellett csökkenést mutatnak. Tehát a szupraoptimális koncentráció fölött, amely bőven a fiziológiás tartomány fölött van, az ATP gátolja az enzimmüködést. Ez logikusan akkor következhet be, ha a natív enzimen vannak olyan extra ATP kötőhelyek, amelyek nem szükségesek a katalitikus aktivitáshoz. Egy korábban megjelent publikációban, ahol a Phaseolus vulgaris GS2 számítógéppel kalkulált háromdimenziós modelljét közölték, feltételezték egy ilyen kötőhely létezését, de azt kísérletes munkával nem bizonyították. Mivel a GS2-t homomer alegységszerkezet jellemzi, az extra ATP-kötőhely az aktív helyek felének reaktivitását (,half-of-the-sites reactivity” vagy „,half-site” reaktivitás) feltételezheti [71]. Ilyen ,halfsite" reaktivitást feltételeztek patkányból izolált GS enzimben is [152]. Egy rekombináns növényi GS ATP kötődését vizsgáló tanulmány arra a következtetésre jutott, hogy minden alegység képes az ATP megkötésére [3].

A fenti két állítás, miszerint minden alegység képes ATP-t megkötni, de az alegységpároknak csak az egyik fele rendelkezik katalitikus aktivitással, eredményeim tükrében nem tekinthető ellentmondónak. Az ATP hatását vizsgáló kinetikai kísérleteink egyben kizárják, hogy az ATP kötődése allosztérikusan szabályozott módon történne. Ez az eredmény egybecseng az ATP kötődését vizsgáló más organizmusban, tanulmánnyal, amely nem említ ilyen felfedezést [3]. Emellett méréseink egyben bizonyítékot is nyújtanak olyan ATP kötőhelyek létezésére, melyek a reakció sztöchiometriájához nem járulnak hozzá.

\subsubsection{A glutaminsav hatása}

A glutaminsav telítési görbéket tanulmányozva két fontos megfigyelésünk volt (14. ábra). Az egyik, hogy a telítési kinetikát széles skálán tanulmányozva a Hill egyenlettel jellemezhetjük a mérési pontok által kirajzolt függvényt. Ez arra utal, hogy a vizsgált enzim allosztérikus kooperativitással rendelkezik. A Hill egyenlet Hill koefficiense 1-nél kisebb szám, amely az allosztérikus negatív kooperativitással jellemezhető mechanizmusokra utal. A görbe jellegét csak a glutaminsav határozza meg, hiszen kizártuk mind a reakció végtermékeinek hatását, valamint sem a hidroxilamin, sem a méréshez alkalmazott ATP mennyisége nem fejt ki negatív hatást az enzim müködésére. Bármely negatív hatás esetén, mivel minden mérési pontban azonosak a reakciókörülmények (nyilván a glutaminsav koncentráció kivételével), 
vagyis a kinetikai viselkedést jellemző függvény szorzójaként értelmezhető, a dimenzióját nem érinti, vagyis csak $V_{\max }$ értékek számadatit érintené, melyet munkámnak nem volt célja pontosan meghatározni, hiszen nem a pontos biokémiai jellemzés, hanem az allosztérikus szabályozás meghatározása volt a cél.

A másik fontos megfigyelés pedig, hogy az enzim glutaminsav telítési görbéin töréspontokat találtunk, melyek nem voltak technikai hibához köthetők. A töréspontok pedig egy lépcsőzetes telítődési görbét írtak le. Ezek a töréspontok egyértelmüvé, kifejezetté váltak a tisztított enzimkivonatok tanulmányozása során. Feltételezhetjük tehát, hogy létezik egy glutaminsav-koncentrációtól függő szubsztrátumfogyasztási dinamika.

$\mathrm{Az}$ eddig elektronmikroszkóppal vizsgált nem rekombináns, kloroplasztisz lokalizált GS fehérje oktamer szerkezetünek bizonyult [70]. Egy olyan közvetlen szerkezetvizsgálat alapján létrehozott modellben, amely a növényi GS holomer összeépülését nem prokarióta modell alapján végezte, szintén arra jutott, hogy a növényi GS oktamer szerkezetű [71]. Az holoenzimet minden eddig vizsgált akár prokarióta, akár eukarióta izoformák esetén dimerek építik fel. Az aktív helyet egy N- és egy C-terminális régió felőli felszín alakítja ki. Nincs is más lehetőség, mint hogy egy alegységpár csak egyetlen katalitikusan aktív helyet tud kialakítani, mivel belátható, hogy az alegységek egyszerre kétfelé nem tudnak fordulni, és az alegységek nem egy nagy folytonos körben állnak. Az ATP kötődésének általunk leírt hatása az enzim aktivitásra és a szakirodalmi adatok [3,71] alapján tehát úgy tünik, hogy a GS-ra jellemző a „half-site” reaktivitás.

Ebből következik, hogy az általunk észlelt lépcsőzetes glutaminsav telítődési kinetika értelmezhető az alegységpárok müködési mechanizmusának eredményeként. Vagyis nem minden alegységpár müködik egyszerre, hanem a glutaminsav-ellátottság növekedésével válnak aktívvá. Ez csak akkor lehetséges, ha a glutaminsavra nézve a dimerek eltérő $K_{\mathrm{s}}$ értékkel rendelkeznek.

Tekintve, hogy a GS homomer alegység összetételü, a $\mathrm{K}_{\mathrm{s}}$ értékek megváltozása nagy valószínüséggel szubsztrátumkötődés által indukált folyamat, akárcsak a hemoglobin esetében [26]. Csakhogy a GS esetében az egyik alegység szubsztrátum kötése gátolja a többi alegység, szubsztrátum kötését, aktivitását. Ennek értelmében, ahhoz, hogy egy következő alegység is aktívvá válhasson a szubsztrátum mennyiségének el kell érnie egy adott küszöbszintet. A folyamat eredményeként a telítődésben ugrások lesznek, vagyis a kinetika lépcsőzetessé válik. A 4 katalitikusan 
aktív alegységpár telítődése esetén pedig logikusan 3 ilyen küszöbszint lesz megfigyelhető a glutaminsav telítési kinetikájában. Ezzel megmagyarázható a négy lépcsős kinetika,

A szubsztrátum-függő dinamika az alacsonyabb glutaminsav-koncentrációtartományban figyelhető meg. A növényekben a glutaminsav koncentrációja a citoszolban és a sztrómában rendre 41 és 26,4 mM [97]. Ettől magasabb értéket csak a floémben mértek [101], annak aktív feltöltődésének eredményeként. Ebböl következik tehát, hogy a GS2-nek a $30 \mathrm{mM}$ alatti glutaminsav-koncentráció-tartományban beálló változásokra kell elsősorban finoman reagálnia, amely limitált szénváz elérhetőséget jelent. A müködésnek ez a finomhangolása biztosítja a rendelkezésre álló szénváz (glutaminsav) szabályozott fogyasztását. Emellett bár csak a szénváz elérhetőségének függvényében ugyan, de az enzim ammóniumion affinitásának köszönhetően a kloroplasztiszban a GS2 nagy hatékonysággal eliminálja a citotoxikus ammóniát. Ennek a finomhangolt müködésnek köszönhetően a kloroplasztisz lokalizált GS megteremti és biokémiai avagy szubsztrátumszinten szabályozza is a kapcsolatot a nitrogén- és a szénanyagcsere között.

\subsection{Fémionok hatása a glutamin-szintetázra}

A GS két bivalens kation-kötőhellyel rendelkező enzim, melynek aktivitásához $\mathrm{a} \mathrm{Mg}^{2+}$ nélkülözhetetlen. Annak hatását már többen vizsgálták, hogy milyen hatással van az egyes növényi GS enzimek aktivitására az ionikus környezet [126,153]. Az alumínium kötődését sikerült kimutatni a búza esetében, mely növeli az enzim aktivitását [126]. Ez a kötődés csak a fémion-kötőhelyek felén valósul meg. Vagyis affinitásuk alapján a prokarióta rendszerekben azonosított $\mathrm{Mg}^{2+}$ specifikus n1 és a kisebb $\mathrm{Mg}^{2+}$-affinitású n2 bivalens kation kötőhelyek a búza GS2-ben is megvannak.

Kísérleteinkben a $\mathrm{Mg}^{2+}$ telítődését (21. ábra), az $\mathrm{Mn}^{2+}$ aktivitásra kifejtett hatását és az $\mathrm{Al}^{3+}$, és $\mathrm{Mn}^{2+}$ glutaminsav telítési kinetikára kifejtett hatását vizsgáltuk meg teljes kivonatokban $\mathrm{Mg}^{2+}$ jelenlétében. $\mathrm{A} \mathrm{Mn}^{2+}$ egyértelműen gátolta az enzim aktivitást teljes kivonatban a telítési $\mathrm{Mg}^{2+}$ koncentráció mellett (23.ábra). Ez alapján feltételeztük, hogy a $\mathrm{Mn}^{2+}$ kötődik az enzimhez. A fémionok kötődése prokariótákban megváltoztatta a GS allosztérikus viselkedését. A glutaminsav telítési kinetikát vizsgáló kísérleteink során nem találtunk arra utaló jelet, hogy a szubsztrátum-ellátottságtól függő 
glutaminsavfogyási dinamika egyértelmủen változna bármely fémion kezelés esetén (22. és 24. ábra). Nem tapasztaltuk a kinetikai görbék egyértelmű eltolódását a kezelések hatására, de a reakciósebességre a fémion ellátottság egyértelműen hatással van.

Az in vitro transzferáz reakció reakciókörülmények nélkül tehát nem valószínü, hogy a glutamin metabolizációja jelentős mértékü lenne teljes kivonatban $\mathrm{Mn}^{2+}$ jelenlétében. Ezt fontos kijelenteni, mivel a homogenizálás során a vakuólumba zárt ionraktárakat is felszabadítjuk.

A GS $\mathrm{Mn}^{2+}$ kötését megvizsgáltuk in vitro bioszintetikus reakciókörülmények között $\mathrm{Mn}^{2+}$ hozzáadásával és hozzáadása nélkül, tisztítás után, ICP-MS méréssel (25. ábra). $\mathrm{A} \mathrm{Mn}^{2+}-\mathrm{t}$ nem tartalmazó kontroll minták a mangánt nem tartalmazták egyértelmüen kimutatható mennyiségben, $\mathrm{a} \mathrm{Mg}^{2+}$ viszont nagy mennyiségben volt jelen. $\mathrm{Mn}^{2+}$-kezelés hatására viszont a $\mathrm{Mg}^{2+}$ tartalom közel a felére csökkent, így biztosan elmondhatjuk, hogy a $\mathrm{Mn}^{2+}$ biztosan hatással van az $\mathrm{n} 2$ kation kötőhely fémion kötésére. Feltételezzük, hogy a $\mathrm{Mn}^{2+}$ a szeparálás során disszociálhatott az n2 kötőhelyröl.

$\mathrm{Az}$ eredmények egyértelmüen mutatják, hogy a $\mathrm{Mn}^{2+}$ hatással van a kisebb $\mathrm{Mg}^{2+}$ affinitású n2 kötőhelyre, mivel a $\mathrm{Mg}^{2+}$ tartalom csökkent. Az viszont nem valószínü, hogy a glutaminsav koncentrációfüggő szubsztrátumfogyási dinamikát, az enzimre jellemző allosztérikus negatív kooperativitást megváltoztatja az $\mathrm{Al}^{3+}$ vagy az $\mathrm{Mn}^{2+}$ jelenléte. 


\section{7. Összefoglalás}

A búza a humán élelmezés egyik legjelentősebb gabonanövénye. Megfelelő nevelési körülmények, a helyes nitrogénellátás nagyban meghatározza a szemtermés minőségét, befolyásolja a raktározott fehérjék mennyiségét és minőségét, ezáltal malom- és sütőipari feldolgozhatóságát. A nitrogénellátás optimalizálásával, vagy hatékonyabb nitrogén-anyagcserével rendelkező növények előállításával mind a terméshozamok, mind a termésminőség növelhető. Ehhez az agrárinnovációhoz, a tudatos, felelősségteljes nemesítéshez, genomszerkesztéshez viszont elengedhetetlen az anyagcsereutak és szabályozó faktoraik mély ismerete.

A GS olyan multimer enzim, amely a GS-GOGAT-GDH ciklus részeként, mely a nitrogén asszimiláció legföbb útvonala, nélkülözhetetlen a búza növekedése és fejlődése során, különös tekintettel a szemfeltöltődés folyamatára. Emellett a GS a nitrogénasszimiláció folyamatában részt vállaló enzimek láncolatának az első olyan tagja, amely a szervetlen nitrogénformát, az ammóniumot képes szénvázhoz kötni. Az ammóniumiont energiabefektetéssel, vagyis ATP hasításával, glutaminsavhoz köti, melynek eredményeként glutamin jön létre.

A glutamin és glutaminsav a szénanyagcsere fontos biokémiai intermedierei, a floémben szállítható nitrogénformák. Emellett egyre inkább úgy tünik, hogy a glutaminsav jelátviteli szereppel bír a növényvilágban is. A GS-nak tehát kiemelkedő szerepe van az anyagcsere-térképen, és talán a metabolikus állapotról közvetítő szignalizációs útvonalakban is. A GS legnagyobb biokémiai jelentősége tehát a szén- és nitrogénanyagcsere kapcsolatlétesítésében rejlik. Ebből kifolyólag feltételeztük, hogy a GS rendelkezik egy rendkívül rövid válaszidejü, effektív, szigorú szabályozási mechanizmussal szubsztrátumszinten, melynek legjobb megfelelője biokémiai szinten az allosztérikus reguláció.

$\mathrm{Az}$ anyagcsere-útvonalakban kiemelt szereppel rendelkező enzimek általában rendelkeznek valamilyen allosztérikus szabályozási mechanizmussal. Az allosztérikus szabályozásnak egy kifinomult, önszabályozást lehetővé tevő formája az allosztérikus kooperativitás. Kooperatív allosztérikus viselkedés biztosíthatja az irányított szubsztrátum fogyasztást. A szubsztrátum jelenléte önmagában elegendő a hatás kiváltásához. A szubsztrátum hasznosítása gyorsabban vagy lassabban mehet végbe attól függően, hogy pozitív, vagy negatív kooperativitásról van szó. Pozitív 
kooperativitás esetén a több szubsztrátumkötő hellyel rendelkező fehérje még nem foglalt soron következő kötőhelyei könnyebben kötik meg a szubsztrátumot az első és rákövetkező kötőhelyek elfoglalása után. Ez lehetőséget ad adott környezetben a gyors telítődésre egy szükebb koncentráció tartományban. Negatív kooperativitás esetén a szubsztrátumkötődés gátolja a soron következő szubsztrátum kötését. Ez egy lassabb telítődést és kevésbé váltakozó ütemü termékképződést biztosít egy széles szubsztrátumkoncentráció tartományban.

Kísérleteinkben vizsgáltuk a GS alegység összetételét, a GS2 allosztérikus szabályozásának, kooperativitásának meglétére utaló bizonyítékokat kerestünk és azonosítottuk a bioszintetikus reakció regulátor szubsztrátumát. Megvizsgáltuk, hogy az alumínium $\left(\mathrm{Al}^{3+}\right)$ és a mangán $\left(\mathrm{Mn}^{2+}\right)$ hatással van-e a felfedett szubsztrátumfüggő mechanizmusokra.

A GS alegység-összetételét kétdimenziós elválasztással (natív + SDS PAGE) egybekötött western blottal vizsgáltuk. Mind a citoplazma eredetű származó GS1, mind a kloroplasztisz eredetü GS2 különálló jelet adott többszöri ismételt vizsgálatok esetén is. Az izoenzimek tehát homogén alegység szerkezettel rendelkeznek, és a GS1 és GS2 egyedi alegységekböl épül fel. Ez megegyezik az irodalomban eddig közölt eredményekkel.

A vizsgálatainkból kiderül, hogy sem a mesterséges szubsztrátum alkalmazása mellett termelődő, sem a természetes termék nem okozza az enzimaktivitás gátlását. Ez nem csak azt jelenti, hogy ezek az anyagok nem zavarják a termékképződést, de egyben azt is kizárhatjuk, hogy a glutamin esetében a termékgátlás mint szabályozási lehetőség felmerülhet.

Tanulmányoztuk a szubsztrátumok szaturációs görbéjét nyers enzimkivonatban, ahol a GS aktivitás 80\%-a a GS2-től származik. Az enzim a hidroxilaminra, vagyis az ammóniumionra nézve rendelkezik a legnagyobb affinitással. A jellegzetes hiperbolikus szaturáció viszont egyben kizárta annak lehetőségét, hogy az $\mathrm{NH}_{4}{ }^{+}$-nak szabályozó hatása lenne. Az ATP szaturációs görbe telítődése Michaelis-Menten kinetikával jól jellemezhető, ami a kooperativitás hiányát jelzi, ennek ellenére viszont a telődés utáni magas ATP koncentrációnál az aktivitás csökkenését tapasztaltuk. Nyers enzimkivonatban a glutaminsav esetén a szubsztrátum szaturációs görbe nehezen telítődött, azon ismételt kísérletekben 3 nem túl kifejezett inflexiós pontot figyeltünk meg. A szaturációs görbét a Hill egyenlettel jellemezhettük a legjobban, 1-nél kisebb Hill koefficienssel. A kinetikai görbét jellemző függvény negatív kooperativitásra utal. 
A nyers enzimkivonatban kapott ATP és glutaminsav szubsztrátumellátottsággal kapcsolatos megfigyeléseink a GS2-t tartalmazó tisztított kivonatokban még inkább kifejezettebbek lettek. Az ATP gátló hatása egyértelművé vált bizonyos ATP-koncentráció felett. Ennek hátterében egy, a reakció sztöchiometriájához nem szükséges ATP-kötőhely állhat. Ez a kísérletes eredmény tovább támogatja, egy eddigiekben nem bizonyított kötőhely létezését. Egyben saját kísérleti eredményünk, és a szakirodalmi adatok összességéből arra következtetünk, hogy az oligomert felépítő monomerek számának a felével egyenlő az aktív helyek száma.

A glutaminsav-szaturáció esetében tapasztalt inflexiós pontokat a korábban észlelt glutaminsav-koncentrációknál kaptuk vissza, melyek a relatíve alacsony, a fiziológiáshoz közeli glutaminsav-tartományra esnek. A töréspontok a görbét 4 részre osztják, mely arra utalhat, hogy 4 katalitikus hely müködését írják le. A Hill egyenlet egyértelmü illeszkedése és a szakaszos telítődés egyértelműen jelzi a negatív kooperativitást. Feltételezzük, hogy a búza GS2 oktamer szerkezetü, mint, ahogyan az eddig leírt nem rekombináns növényi glutamin szintetázok, és az enzimnek a glutamisav allosztérikus regulátor szubsztrátuma.

A fenti eredmények alapján a GS2 működése leírható egy olyan függvénnyel, amely 4 olyan függvény, azaz Hill egyenlet összege, melynek mindegyikét egy 1-nél alacsonyabb Hill koefficiens és sorra növekvő $\mathrm{K}_{\mathrm{s}}$ érték jellemzi.

A fémionok hatását elemző vizsgálataink nem adtak olyan eredményt, amely arra utalt volna, hogy a GS2 szubsztrátumfüggő telítési dinamikája megváltozna $\mathrm{Mn}^{2+}$, vagy $\mathrm{Al}^{3+}$ hatására. $\mathrm{A} \mathrm{Mg}^{2+}$ kötődése viszont esszenciális az enzim aktivitása szempontjából. Emellett bár az $\mathrm{Mn}^{2+}$ kötődését nem tudtuk közvetlenül kimutatni, de az egyértelmü, hogy a $\mathrm{Mg}^{2+}$ ionok leszorításáért az n2 kötőhelyekröl az $\mathrm{Mn}^{2+}$ tehető felelőssé, ezzel csökkentve a GS aktivitást. A fémionok tehát nem a glutaminsav kötődésének befolyásolásán keresztül vannak hatással az enzim aktivitására.

A kloroplasztiszban lokalizált GS müködését tehát a glutaminsav allosztérikusan szabályozza. A glutaminsav mint regulátor szubsztrátum felhasználását az enzim felépítéséből eredö, az alegységei között fellépő allosztérikus negatív kooperativitás vezérli. Ezáltal a GS lehetővé teszi a glutaminsav mint fontos metabolikus intermedier és jelmolekula, fokozatos felhasználását egy széles, fiziológiás koncentrációtartományon. A negatív kooperativitásnak köszönhetően a GS2 nemcsak a nitrogén asszimilációban, de egyúttal a szén-nitrogén egyensúly fenntartásában is fontos szerepet tölt be, amelyet új növényfajták létrehozásánál számításba kell vennünk. 
A dolgozatban bemutatott legfontosabb új tudományos eredmények tehát a következők:

- A búzanövény levelének kloroplasztiszban lokalizált GS2 izoenzime allosztérikusan szabályozott.

- A felfedezett allosztérikus szabályozás háttere az allosztérikus negatív kooperativitás, melynek regulátor szubsztrátuma a glutaminsav.

- A szabályozás leírására egy új, saját, közelítő matematikai modellt hoztunk létre.

- A matematikai modellt egy új GS2 müködési modellel társítottuk.

- Az ATP szupraoptimális koncentrációban gátolja a kloroplasztiszban lokalizált glutamin-szintetáz aktivitását in vitro.

- Búzában a $\mathrm{Mn}^{2+}$ a GS2 $\mathrm{Mg}^{2+}$-kötöhelyeinek feléröl, feltehetöleg a kis $\mathrm{Mg}^{2+}$-affinitású $\mathrm{n} 2$ fémionkötőhelyekröl leszorítja a $\mathrm{Mg}^{2+}$-ot. 


\section{Summary}

Wheat is one of the most important cereal of human nutrition, The proper growth conditions and nitrogen supply largely determine the yield quality, affect the protein content and the quality of grain stored protein. Optimizing the nitrogen supply or breedeing plats with mor efficient nitrogen metabolism can increase grain yields and yield quality. The deep knowledge of metabolic pathways and their regulation elements and mechanisms is essential for the implementation of this agricultural innovation, and for the conscious, responsible breeding and genome editing processes.

The glutamine synthetase is a multimeric enzyme and part of the GS GOGATGDH cycle, which is the main route for nitrogen assimilation. Hence GS is indispensable for the adequate growth and development of wheat, and extremely important for proper grain gilling process. Besides GS is the first enzyme in the concatenation of the enzymes of nitrogen uptake, which is able to bind inorganic nitrogen, ammonium, to an organic compound. GS binds the ammonium ion to glutamic acid and produces glutamine, while the cleavage of one ATP molecule covers the energy cost of the reaction.

The glutamine and the glutamic acid are important biochemical intermediates of the carbon metabolism, and also transportable nitrogen forms via the phloem. Additionally glutamic acid appears to have an emerging role in signal transduction in the kingdom of plants. Thus GS has a significant function in metabolism, and perhaps in the signaling pathways which mediate metabolic status. In summary, the greatest biological significance of GS is making the connection between the nitrogen and carbon cycle. Therefore we suggested that GS has a prompt, strict and effective regulation mechanism at the level of substrates. The most appropriate version for this kind of regulation mechanism at the biochemical level can be the allosteric regulation.

It is not outstanding, that enzymes with a prominent role in metabolic pathways possess allosteric regulatory mechanisms. A special form of allostery, which enables a more sophisticated autoregulation, is the allosteric cooperativity. The allosteric cooperative behavior can ensure the controlled substrate consumption. The presence of the substrate itself triggers the induction of the allosteric effect. The utilization of the substrate can eventuate faster or slower depending on whether positive or negative cooperativity is involved in the process. In case of positive cooperativity the binding of 
the substrate facilitates the binding of the subsequent one at an unoccupied substrate binding site on the catalytic site of a protein with multiple binding sites. This mechanism allows fast saturation in a narrower substrate concentration range. In turn, in case of negative cooperativity the binding of the substrate detain the binding of the subsequent one. This mechanism ensures a slower saturation, and a less alternating product formation rate in a wider substrate concentration range.

In this work the homogeneity of the subunit composition and the allosteric regulation, the cooperative behavior of chloroplast glutamine synthetase was studied. We investigated and identified the regulator substrate of the biosynthetic reaction. The effect of aluminum $\left(\mathrm{Al}^{3+}\right)$ and manganese $\left(\mathrm{Mn}^{2+}\right)$ on the revealed substrate dependent mechanisms was also examined.

The subunit composition of glutamine synthetase was examined by the combination of two dimensional gel electrophoresis (native + SDS) and western blot. Both GS1 and GS2 of leaves provided separate identical spots on the protein blot in multiple repeated tests. Hence the isoenzymes composed of identical, homomer subunits. This result is in accordance with the current stand of the literature.

The effect of substrates and products on GS activity in crude protein extracts of leaves was investigated. Our results show, that neither the artefactual, nor the natural product has no inhibitory effect on the enzyme activity. This does not only mean that these compounds do not interfere with product formation, but we can also exclude product inhibition as a regulatory option in case of glutamine.

The saturation curves of the substrates were studied in crude extract, where $80 \%$ of the GS activity derives from GS2. The enzyme has the highest affinity for hydroxylamine, thus ammonium ion. The typical hyperbolic saturation, however, excluded the possibility that $\mathrm{NH}_{4+}$ would have a regulatory effect. The saturation curve for ATP can be well characterized by Michaelis-Menten kinetics, which indicates the lack of allosteric cooperative effects, however after the eventuation of full saturation a decrease in activity was observed at high ATP concentrations. In crude extracts glutamic acid kinetic curves showed impeded saturation and 3 reproducible inflection points were observed. The curve was best characterized by the Hill equation with a Hill coefficient of less than 1 . This mathematical function indicates the possibility that GS2 possesses allosteric negative cooperativity.

The results of ATP and glutamic acid assays of crude extracts were more pronounced in case of the repeated experiments using purified GS2. The inhibitory 
effect of ATP has become clear. We suggest that this effect is owing to extra ATP binding sites, which are not necessary for the stoichiometry of the reaction. This experimental result supports the existence of an undetermined binding site. In addition, our own experimental results and all the literature data suggest that the number of active sites is equal to half the number of oligomer-forming monomers.

The inflection points of the glutamic acid saturation curves in case of purified GS2 extracts were the same as in case of crude extracts. The eminent glutamic acid concentrations belonging to the inflection points are in the range of physiological intracellular glutamic acid concentration range. These breakpoints divide the curve into 4 parts, which appears to indicate the existence of four catalytically active sites. The unequivocally fitting Hill equation allows determining GS2 as an enzyme possessing allosteric negative cooperativity. We suggest, that the chloroplast localized GS of wheat is an octamer, as the far described non-recombinant plant glutamine synthetase isoenzymes, and glutamic acid is its regulatory substrate.

Based on the above results, the operational mechanism of GS2 can be described by a function that is a sum of four functions, actually Hill equations, all of which are characterized by a Hill coefficient less than 1 and growing $\mathrm{K}_{\mathrm{s}}$ value.

Analysis of the effects of metal ions did not resulted in any evidence suggesting that the dependent saturation dynamics of the GS2 substrate would change in response to $\mathrm{Mn}^{2+}$ or $\mathrm{Al}^{3+}$ treatment. We clarified that the binding of $\mathrm{Mg}^{2+}$ was indispensable for enzyme activity. In addition, although we could not directly prove the binding of $\mathrm{Mn}^{2+}$, it is obvious that $\mathrm{Mn}^{2+}$ is responsible for the dissociation of $\mathrm{Mg}^{2+}$ ions from the $\mathrm{n} 2$ cation binding sites, thereby reducing GS activity. Metal ions therefore do not influence the activity of the enzyme via affecting the binding of glutamic acid.

In summary, the operation of the localized glutamine synthetase of wheat chloroplast is allosterically regulated by glutamic acid. The utilization of glutamic acid as a regulatory substrate is driven by the allosteric negative cooperativity activity, which derives from the intramolecular interactions of the subunits, the assemblage of the holoenzyme. Thus GS allows gradual utilization of glutamic acid, an important metabolic intermediate and signal molecule, in a wide range of physiological concentrations. Due to the negative cooperative behavior, GS2 plays an important role not only in the assimilation of nitrogen but also in the maintenance of carbon-nitrogen balance, which should be considered in the case of breeding or editing new plant varieties. 


\section{Summary}

The most important new scientific results presented in the thesis are as follows:

- The chloroplasts localized GS2 isoenzyme of wheat leaves is under allosteric regulation.

- The background of allosteric regulation is allosteric negative cooperativity driven by the regulatory substrate which has been identified as glutamic acid.

- To describe this regulation, we have created a new, approximate mathematical model.

- The mathematical model can be associated with our newly introduced mechanistic model of GS2.

- Supraoptimal ATP concentration inhibits the activity of GS2 in vitro.

- In case of wheat GS2 half of the bound $\mathrm{Mg}^{2+}$ can be displaced by $\mathrm{Mn}^{2+}$, presumably this change occurs at the $\mathrm{n} 2$ metal binding sites, which have lower $\mathrm{Mg}^{2+}$ affinity. 


\section{Felhasznált irodalom}

[1] T. Qiuying, L. Nana, W. Bai, L. Li, J. Chen, P.B. Reich, Q. Yu, D. Guo, M.D. Smith, A.K. Knapp, W. Cheng, P. Lu, Y. Gao, A. Yang, T. Wang, X. Li, Z. Wamg, Y. Ma, X. Han, W.-H. Zhang, A novel soil manganese mechanism drives plant species loss with increased nitrogen deposition in a temperate steppe, Ecology. 97 (2016) 65-74. doi:10.1890/15-0917.1.

[2] B.J. Miflin, D.Z. Habash, The role of glutamine synthetase and glutamate dehydrogenase in nitrogen assimilation and possibilities for improvement in the nitrogen utilization of crops, J. Exp. Bot. 53 (2002) 979-987. doi:10.1093/jexbot/53.370.979.

[3] M. Betti, A.J. Márquez, C. Yanes, A. Maestre, ATP binding to purified homopolymeric plant glutamine synthetase studied by isothermal titration calorimetry, Thermochim. Acta. 394 (2002) 63-71. doi:10.1016/S0040-6031(02)00239-3.

[4] M.S. Balakrishnan, J.J. Villafranca, J.E. Brenchley, Glutamine synthetase from Salmonella typhimurium: Manganese(II), substrate, and inhibitor interaction with the unadenylylated enzyme, Arch. Biochem. Biophys. 181 (1977) 603-615. doi:10.1016/0003-9861(77)90267-3.

[5] M. Leason, D. Cunliffe, D. Parkin, P.J. Lea, B.J. Miflin, Inhibition of pea leaf glutamine synthetase by methionine sulphoximine, phosphinotricin and other glutamate analogues, Phytochemistry. 21 (1982) 855-857.

[6] D. O’Neal, K.W. Joy, Glutamine Synthetase of Pea Leaves, Plant Physiol. 54 (1974) 773-779. doi:10.1104/pp.54.5.773.

[7] C. Guiz, B. Hirel, G. Shedlofsky, P. Gadal, Occurence and influence of light on the relative proportions of two glutamine synthetases in rice leaves, Plant Sci. Lett. 15 (1979) 271-277.

[8] D.H.P. Barratt, Method for the detection of glutamine synthetase activity on starch gels, Plant Sci. Lett. 18 (1980) 249-255. doi:10.1016/0304-4211(80)90115-7.

[9] D. Rhodes, G.A. Rendon, G.R. Stewart, The control of glutamine synthetase level in Lemna minor L., Planta. 125 (1975) 201-211. doi:10.1007/BF00385596.

[10] J.H. Peng, D. Sun, E. Nevo, Domestication evolution, genetics and genomics in wheat, Mol. Breed. 28 (2011) 281-301. doi:10.1007/s11032-011-9608-4.

[11] G. Petersen, O. Seberg, M. Yde, K. Berthelsen, Phylogenetic relationships of Triticum and Aegilops and evidence for the origin of the A, B, and D genomes of common wheat (Triticum aestivum), Mol. Phylogenet. Evol. 39 (2006) 70-82. doi:10.1016/j.ympev.2006.01.023.

[12] Z. Nagy, E. Németh, A. Guóth, L. Bona, B. Wodala, A. Pécsváradi, Metabolic indicators of drought stress tolerance in wheat: Glutamine synthetase isoenzymes and Rubisco, Plant Physiol. Biochem. 67 (2013) 48-54. doi:10.1016/j.plaphy.2013.03.001.

[13] H. Shi, B. Wang, P. Yang, Y. Li, F. Miao, Differences in sugar accumulation and mobilization between sequential and non-sequential senescence wheat cultivars under natural and drought conditions, PLoS One. 11 (2016) 1-17. doi:10.1371/journal.pone.0166155.

[14] A. Distelfeld, R. Avni, A.M. Fischer, Senescence, nutrient remobilization, and yield in wheat and barley, J. Exp. Bot. 65 (2014) 3783-3798. doi:10.1093/jxb/ert477.

[15] C. Caputo, M.V. Criado, I.N. Roberts, M.A. Gelso, A.J. Barneix, Regulation of glutamine synthetase 1 and amino acids transport in the phloem of young wheat plants, Plant Physiol. Biochem. 47 (2009) 335-342. doi:10.1016/j.plaphy.2009.01.003.

[16] R.J. Yon, A contrast in allostery: aspartate transcarbamyolases from wheat and from Escherichia coli, Biochem.Soc.Trans. 17 (1989) 564-565. doi:10.1042/bst0170564.

[17] M.A. Acaster, S. Scott-white, P.D.J. Weitzman, Carbamoyltransferase reactions in plants. A survey for enzymic diversity and the potential for herbicidal activity of transition state analogue inhibitors, J. Exp. Bot. 40 (1989) 1121-1125. doi:10.1093/jxb/40.10.1121. 
[18] M.J. Easton, R.J. Yon, Inactivation of wheat-germ aspartate transcarbamoylase by the triazinyl dye, Procion Red HE3B, Biochim. Biophys. Acta (BBA)/Protein Struct. Mol. 1118 (1992) 298-302. doi:10.1016/0167-4838(92)90288-O.

[19] J.J. Tyson, K.C. Chen, B. Novak, Sniffers, buzzers, toggles and blinkers: Dynamics of regulatory and signaling pathways in the cell, Curr. Opin. Cell Biol. 15 (2003) 221-231. doi:10.1016/S0955-0674(03)00017-6.

[20] M. Vivoli, J. Pang, N.J. Harmer, A half-site multimeric enzyme achieves its cooperativity without conformational changes, Sci. Rep. 7 (2017) 16529. doi:10.1038/s41598-017-16421-2.

[21] A.W. Fenton, Allostery: an illustrated definition for the "second secret of life," Trends Biochem. Sci. 33 (2008) 420-425. doi:10.1016/j.tibs.2008.05.009.

[22] J.P. Changeux, 50th anniversary of the word "allosteric," Protein Sci. 20 (2011) 11191124. doi:10.1002/pro.658.

[23] K. Wilson, R. Baydoun, A., K. Ohlendieck, W. Paddock, S., R. Rapley, R. Burns, M. Walker, J., A. Aitken, J. Walker, A. Hofmann, R. Slater, J. Fyffe, Principles and techniques of biochemistry and molecular biology, 7th ed., Cambridge University Press, 2010.

[24] P.A. Frey, A.D. Hegeman, Enzymatic Reaction Mechanisms., 1st ed., Oxford University Press, New York, 2007. doi:10.1002/ange.200785514.

[25] M.L. Cárdenas, Michaelis and Menten and the long road to the discovery of cooperativity, FEBS Lett. 587 (2013) 2767-2771. doi:10.1016/j.febslet.2013.07.014.

[26] A. V. Hill, The possible effects of the aggregation of the molecule of hemoglobin on its dissociation curves., J. Physiol. 40 (1910) iv-vii. doi:10.1017/CBO9781107415324.004.

[27] A.V. Hill, The combinations of haemoglobin with oxygen and with carbon monoxide. I., Biochem. J. 7 (1913) 471-480. doi:10.1042/bj0070471.

[28] D.E. Koshland, The structural basis of negative cooperativity: Receptors and enzymes, Curr. Opin. Struct. Biol. 6 (1996) 757-761. doi:10.1016/S0959-440X(96)80004-2.

[29] T.W. Becker, M. Caboche, E. Carrayol, B. Hirel, Nucleotide sequence of a tobacco cDNA encoding plastidic glutamine synthetase and light inducibility, organ specificity and diurnal rhythmicity in the expression of the corresponding genes of tobacco and tomato, Plant Mol. Biol. 19 (1992) 367-379. doi:10.1007/BF00023384.

[30] L. Michaelis, M.L. Menten, Die Kinetik der Invertinwirkung, Biochem. Z. 49 (1913) 333-369. doi:10.1021/bi201284u.

[31] J. Monod, J. Wyman, J.P. Changeux, On the nature of allosteric transitions: A plausible model, J. Mol. Biol. 12 (1965) 88-118. doi:10.1016/S0022-2836(65)80285-6.

[32] A. Levitzki, D.E. Koshland, Negative cooperativity in regulatory enzymes, Proc. Natl. Acad. Sci. 62 (1969) 1121-1128. doi:10.1073/pnas.62.4.1121.

[33] D.E. Koshland, G. Némethy, D. Filmer, Comparison of experimental binding data and theoretical models in proteins containing subunits, Biochemistry. 5 (1966) 365-385. doi:10.1021/bi00865a047.

[34] S.A. Bernhard, R.A. MacQuarrie, Half-site reactivity and the "induced-fit" hypothesis, J. Mol. Biol. 74 (1973) 73-78. doi:10.1016/0022-2836(73)90356-2.

[35] D.H. Rao, L.R. Gowda, The D-galactose specific lectin of field bean (Dolichos lablab) seed binds sugars with extreme negative cooperativity and half-of-the-sites binding, Arch. Biochem. Biophys. 524 (2012) 85-92. doi:10.1016/j.abb.2012.05.005.

[36] V.C. Sershon, B.D. Santarsiero, A.D. Mesecar, Kinetic and X-ray structural Evidence for negative cooperativity in substrate binding to nicotinate mononucleotide adenylyltransferase (NMAT) from Bacillus anthracis, J. Mol. Biol. 385 (2009) 867-888. doi:10.1016/j.jmb.2008.10.037.

[37] E.C. Bush, A.E. Clark, C.M. DeBoever, L.E. Haynes, S. Hussain, S. Ma, M.M. McDermott, A.M. Novak, J.S. Wentworth, Modeling the role of negative cooperativity in metabolic regulation and homeostasis, PLoS One. 7 (2012) 1-6. doi:10.1371/journal.pone.0048920.

[38] T. Traut, Enzyme Activity : Allosteric Regulation, ELS. John Wiley Sons Ltd, Chichester. Http//Www.Els.Net. (2014). doi:10.1002/9780470015902.a0000865.pub3. 
[39] G. Li, P. Tillard, A. Gojon, C. Maurel, Dual regulation of root hydraulic conductivity and plasma membrane aquaporins by plant nitrate accumulation and high-affinity nitrate transporter NRT2.1, Plant Cell Physiol. 57 (2016) 733-742. doi:10.1093/pcp/pcw022.

[40] P.J. Lea, J.-F. Morot-Gaudry, Plant nitrogen, 1st ed., Springer-Verlag Berlin Heidelberg, New York, 2001.

[41] J.A.A. O’Brien, A. Vega, E. Bouguyon, G. Krouk, A. Gojon, G. Coruzzi, R.A.A. Gutiérrez, Nitrate Transport, Sensing, and Responses in Plants, Mol. Plant. 9 (2016) 837-856. doi:10.1016/j.molp.2016.05.004.

[42] J. Sun, J.R. Bankston, J. Payandeh, T.R. Hinds, W.N. Zagotta, N. Zheng, Crystal structure of the plant dual-affinity nitrate transporter NRT1.1, Nature. 507 (2014) 73-77. doi:10.1038/nature13074.

[43] A. Gojon, G. Krouk, F. Perrine-Walker, E. Laugier, Nitrate transceptor(s) in plants, J. Exp. Bot. 62 (2011) 2299-2308. doi:10.1093/jxb/erq419.

[44] G. Krouk, B. Lacombe, A. Bielach, F. Perrine-Walker, K. Malinska, E. Mounier, K. Hoyerova, P. Tillard, S. Leon, K. Ljung, E. Zazimalova, E. Benkova, P. Nacry, A. Gojon, Nitrate-regulated auxin transport by NRT1.1 defines a mechanism for nutrient sensing in plants, Dev. Cell. 18 (2010) 927-937. doi:10.1016/j.devcel.2010.05.008.

[45] Y. Kanno, A. Hanada, Y. Chiba, T. Ichikawa, M. Nakazawa, M. Matsui, T. Koshiba, Y. Kamiya, M. Seo, Identification of an abscisic acid transporter by functional screening using the receptor complex as a sensor, Proc. Natl. Acad. Sci. 109 (2012) 9653-9658. doi:10.1073/pnas.1203567109.

[46] J.-J. Zhou, F.L. Theodoulou, I. Muldin, B. Ingemarsson, A.J. Miller, Cloning and functional characterization of a Brassica napus transporter that is able to transport nitrate and histidine, J. Biol. Chem. 273 (1998) 12017-12023. doi:10.1074/jbc.273.20.12017.

[47] J.H. Sherrard, J.A. Kennedy, M.J. Dalling, In Vitro Stability of Nitrate Reductase from Wheat Leaves: III. Isolation and Partial Characterization of a Nitrate Reductaseinactivating Factor., Plant Physiol. 64 (1979) 640-645.

[48] T. Schöndorf, W. Hachtel, The choice of reducing substrate is altered by replacement of an alanine by a proline in the FAD domain of a bispecific $\mathrm{NAD}(\mathrm{P}) \mathrm{H}$-nitrate reductase from birch., Plant Physiol. 108 (1995) 203-10. doi:10.1104/pp.108.1.203.

[49] A.R. Harker, K.R. Narayanan, R.L. Warner, A. Kleinhofs, NAD(P)H Bispecific nitrate reductase in barley leaves: Partial purification and characterization, Phytochemistry. 25 (1986) 1275-1279. doi:10.1016/S0031-9422(00)81271-6.

[50] M.G. Redinbaugh, W.H. Campbell, Quaternary structure and composition of squash NADH:nitrate reductase., J. Biol. Chem. 260 (1985) 3380-3385.

[51] W.H. Campbell, Structure and function of eukaryotic NAD(P)H:nitrate reductase, Cell. Mol. Life Sci. 58 (2001) 194-204. doi:10.1007/PL00000847.

[52] L.P. Solomonson, M.J. Barber, Assimilatory nitrate reductase: functional properties and regulation, Annu. Rev. Plant Physiol. Plant Mol. Biol. 41 (1990) 225-253. doi:10.1146/annurev.pp.41.060190.001301.

[53] C. Stöhr, R.U. Wolfram, A succinate-oxidising nitrate reductase is located at the plasma membrane of plant roots, Planta. 203 (1997) 129-132. doi:10.1007/s00050173.

[54] P. Rockel, F. Strube, A. Rockel, J. Wildt, W.M. Kaiser, Regulation of nitric oxide (NO) production by plant nitrate reductase in vivo and in vitro, J. Exp. Bot. 53 (2002) 103110. doi:10.1093/jxb/53.366.103.

[55] R. Sturms, A.A. Dispirito, M.S. Hargrove, Plant and cyanobacterial hemoglobins reduce nitrite to nitric oxide under anoxic conditions, Biochemistry. 50 (2011) 3873-3878. doi:10.1021/bi2004312.

[56] M. Sugiura, M.N. Georgescu, M. Takahashi, A nitrite transporter associated with nitrite uptake by higher plant chloroplasts, Plant Cell Physiol. 48 (2007) 1022-1035. doi:10.1093/pcp/pcm073.

[57] J. Rexach, E. Fernández, A. Galván, The Chlamydomonas reinhardtii Narl Gene Encodes a Chloroplast Membrane Protein involved in Nitrite Transport, Plant Cell. 12 (2000) 1441-1453. doi:10.1105/tpc.12.8.1441.

[58] D. Loqué, S. Lalonde, L.L. Looger, N. Von Wirén, W.B. Frommer, A cytosolic trans- 
activation domain essential for ammonium uptake, Nature. 446 (2007) 195-198. doi:10.1038/nature05579.

[59] S.M. Howitt, M.K. Udvardi, Structure, function and regulation of ammonium transporters in plants, Biochim. Biophys. Acta - Biomembr. 1465 (2000) 152-170. doi:10.1016/S0005-2736(00)00136-X.

[60] J.E. Johnson, J.A. Berry, The influence of leaf-atmosphere $\mathrm{NH}_{3(\mathrm{~g})}$ exchange on the isotopic composition of nitrogen in plants and the atmosphere, Plant, Cell Environ. 36 (2013) 1783-1801. doi:10.1111/pce.12087.

[61] S. Balotf, G. Kavoosi, B. Kholdebarin, Nitrate reductase, nitrite reductase, glutamine synthetase and glutamate synthase expression and activity in response to different nitrogen sources in nitrogen-starved wheat seedlings, Biotechnol. Appl. Biochem. 63 (2016) 220-229. doi:10.1002/bab.1362.

[62] J.M. van Rooyen, V.R. Abratt, H. Belrhali, T. Sewell, Crystal structure of type III glutamine synthetase: Surprising reversal of the inter-ring interface, Structure. 19 (2011) 471-483. doi:10.1016/j.str.2011.02.001.

[63] H. Unno, T. Uchida, H. Sugawara, G. Kurisu, T. Sugiyama, T. Yamaya, H. Sakakibara, T. Hase, M. Kusunoki, Atomic structure of plant glutamine synthetase: A key enzyme for plant productivity, J. Biol. Chem. 281 (2006) 29287-29296. doi:10.1074/jbc.M601497200.

[64] J.R. Almassy, C.A. Janson, R. Hamlin, N.-H. Xuong, D. Eisenberg, Novel subunitsubunit interactions in the structure of glutamine synthetase, Nature. 323 (1986) 304 309. doi:10.1038/320129a0.

[65] P. Jiang, A.J. Ninfa, Reconstitution of Escherichia coli glutamine synthetase adenylyltransferase from $\mathrm{N}$-terminal and $\mathrm{C}$-terminal fragments of the enzyme, Biochemistry. 48 (2009) 415-423. doi:10.1021/bi801775b.

[66] D. Eisenberg, H.S. Gill, M.U.P. Gaston, S.H. Rotstein, Structure-function relationships of glutamine synthetases, Biochim. Biophys. Acta. 1477 (2000) 122-145. doi:10.1016/S0167-4838(99)00270-8.

[67] E.R. Stadtman, The story of glutamine synthetase regulation, J. Biol. Chem. 276 (2001) 44357-44364. doi:10.1074/jbc.R100055200.

[68] A.R. Seabra, H. Carvalho, P.J.B. Pereira, Crystallization and preliminary crystallographic characterization of glutamine synthetase from Medicago truncatula, Acta Crystallogr. Sect. F Struct. Biol. Cryst. Commun. 65 (2009) 1309-1312. doi:10.1107/S1744309109047381.

[69] V.L. Tsuprun, T.G. Samsonidze, N.A. Radukina, A. V. Pushkin, Z.G. Evstigneeva, W.L. Kretovich, Electron microscopy of glutamine synthetase from pea leaf chloroplasts, BBA - Protein Struct. 626 (1980) 1-4. doi:10.1016/0005-2795(80)90190-7.

[70] A. V. Pushkin, L.P. Antoniuk, N.A. Solovieva, V. V. Shubin, Z.G. Evstigneeva, W.L. Kretovich, T. V. Cherednikova, T.L. Vladimir, O.N. Zograf, N.A. Kiselev, Glutamine synthetases of pea leaf and seed cytosol. Structure and properties, Biochim. Biophys. Acta. 828 (1985) 336-350.

[71] O. Llorca, M. Betti, J.M. González, A. Valencia, A.J. Márquez, J.M. Valpuesta, The three-dimensional structure of an eukaryotic glutamine synthetase: Functional implications of its oligomeric structure, J. Struct. Biol. 156 (2006) 469-479. doi:10.1016/j.jsb.2006.06.003.

[72] M. Zolkiewski, N.J. Nosworthy, A. Ginsburg, Urea-induced dissociation and unfolding of dodecameric glutamine synthetase from Escherichia coli: Calorimetric and spectral studies, Protein Sci. 4 (1995) 1544-1552. doi:10.1002/pro.5560040812.

[73] G. Mäck, R. Tischner, Glutamine synthetase oligomers and isoforms in sugar beet ( Beta vulgaris L. ), Planta. 181 (1990) 10-17. doi:10.1007/BF00202319.

[74] L. Lima, A. Seabra, P. Melo, J. Cullimore, H. Carvalho, Phosphorylation and subsequent interaction with 14-3-3 proteins regulate plastid glutamine synthetase in Medicago truncatula, Planta. 223 (2006) 558-567. doi:10.1007/s00425-005-0097-8.

[75] T. Osanai, A. Kuwahara, H. Otsuki, K. Saito, M. Yokota Hirai, ACR11 is an Activator of Plastid-Type Glutamine Synthetase GS2 in Arabidopsis thaliana, Plant Cell Physiol. 
58 (2017) 650-657. doi:10.1093/pcp/pcx033.

[76] A. Takabayashi, A. Niwata, A. Tanaka, Direct interaction with ACR11 is necessary for post-transcriptional control of GLU1-encoded ferredoxin-dependent glutamate synthase in leaves, Sci. Rep. 6 (2016) 1-10. doi:10.1038/srep29668.

[77] Y.A. Choi, S.G. Kim, Y.M. Kwon, The plastidic glutamine synthetase activity is directly modulated by means of redox change at two unique cysteine residues, Plant Sci. 149 (1999) 175-182. doi:10.1016/S0168-9452(99)00163-6.

[78] P.M. Melo, L.S. Silva, I. Ribeiro, A.R. Seabra, H.G. Carvalho, Glutamine synthetase is a molecular target of nitric oxide in root nodules of Medicago truncatula and is regulated by tyrosine nitration, Plant Physiol. 157 (2011) 1505-1517. doi:10.1104/pp.111.186056.

[79] N. Konishi, K. Ishiyama, M.P. Beier, E. Inoue, K. Kanno, T. Yamaya, H. Takahashi, S. Kojima, Contributions of two cytosolic glutamine synthetase isozymes to ammonium assimilation in Arabidopsis roots, J. Exp. Bot. 68 (2017) 613-625. doi:10.1093/jxb/erw454.

[80] A. Grabowska, J. Kwinta, W. Bielawski, Glutamine synthetase and glutamate dehydrogenase in triticale seeds: Molecular cloning and genes expression, Acta Physiol. Plant. 34 (2012) 2393-2406. doi:10.1007/s11738-012-1085-9.

[81] K. Ishiyama, E. Inoue, M. Tabuchi, T. Yamaya, H. Takahashi, Biochemical background and compartmentalized functions of cytosolic glutamine synthetase for active ammonium assimilation in rice roots., Plant Cell Physiol. 45 (2004) 1640-7. doi:10.1093/pcp/pch190.

[82] S. Timm, A. Florian, S. Arrivault, M. Stitt, A.R. Fernie, H. Bauwe, Glycine decarboxylase controls photosynthesis and plant growth, FEBS Lett. 586 (2012) 36923697. doi:10.1016/j.febslet.2012.08.027.

[83] T. Kisaki, A. Imai, N.E. Tolbert, Intracellular localization of enzymes related to photorespiration in green leaves, Plant Cell Physiol. 12 (1971) 267-273. doi:10.1093/oxfordjournals.pcp.a074620.

[84] M. Linka, A.P.M. Weber, Shuffling ammonia between mitochondria and plastids during photorespiration, Trends Plant Sci. 10 (2005) 461-465. doi:10.1016/j.tplants.2005.08.002.

[85] J.W. Edwards, G.M. Coruzzi, Photorespiration and light act in concert to regulate the expression of the nuclear gene for chloroplast glutamine synthetase., Plant Cell. 1 (1989) 241-248. doi:10.1105/tpc.1.2.241.

[86] E. Kumagai, T. Araki, N. Hamaoka, O. Ueno, Ammonia emission from rice leaves in relation to photorespiration and genotypic differences in glutamine synthetase activity, Ann. Bot. 108 (2011) 1381-1386. doi:10.1093/aob/mcr245.

[87] S.A. Robinson, A.P. Slade, G.G. Fox, R. Phillips, R.G. Ratcliffe, G.R. Stewart, G. Street, L.W.S.A. R, R.E.T. Al, The role of glutamate dehydrogenase in plant nitrogen metabolism, Plant Physiol. 95 (1991) 509-516.

[88] S.M. Bernard, A.L.B. Møller, G. Dionisio, T. Kichey, T.P. Jahn, F. Dubois, M. Baudo, M.S. Lopes, T. Tercé-Laforgue, C.H. Foyer, M.A.J. Parry, B.G. Forde, J.L. Araus, B. Hirel, J.K. Schjoerring, D.Z. Habash, Gene expression, cellular localisation and function of glutamine synthetase isozymes in wheat (Triticum aestivum L.), Plant Mol. Biol. 67 (2008) 89-105. doi:10.1007/s11103-008-9303-y.

[89] M. Lancien, P. Gadal, M. Hodges, Enzyme redundancy and the importance of 2Oxoglutarate in higher plant ammonium assimilation, Plant Physiol. 123 (2000) 817824. doi:10.1104/pp.123.3.817.

[90] P.J. Lea, B.J. Miflin, Glutamate synthase and the synthesis of glutamate in plants, Plant Physiol. Biochem. 41 (2003) 555-564. doi:10.1016/S0981-9428(03)00060-3.

[91] R. Nkoa, Y. Desjardins, N. Tremblay, Glutamine synthetase in broccoli (Brassica oleracea) is regulated in vivo by reciprocal cooperativity, New Phytol. 158 (2003) 139149. doi:10.1046/j.1469-8137.2003.00717.x.

[92] R.M. Wallsgrove, J.C. Turner, N.P. Hall, a C. Kendall, S.W. Bright, Barley mutants lacking chloroplast glutamine synthetase-biochemical and genetic analysis., Plant Physiol. 83 (1987) 155-158. doi:10.1104/pp.83.1.155. 
[93] A. Bao, Z. Zhao, G. Ding, L. Shi, F. Xu, H. Cai, The stable level of glutamine synthetase 2 plays an important role in rice growth and in carbon-nitrogen metabolic balance, Int. J. Mol. Sci. 16 (2015) 12713-12736. doi:10.3390/ijms160612713.

[94] H. Cai, Y. Zhou, J. Xiao, X. Li, Q. Zhang, X. Lian, Overexpressed glutamine synthetase gene modifies nitrogen metabolism and abiotic stress responses in rice, Plant Cell Rep. 28 (2009) 527-537. doi:10.1007/s00299-008-0665-z.

[95] M. Taniguchi, H. Miyake, Redox-shuttling between chloroplast and cytosol: Integration of intra-chloroplast and extra-chloroplast metabolism, Curr. Opin. Plant Biol. 15 (2012) 252-260. doi:10.1016/j.pbi.2012.01.014.

[96] K.C. Woo, U.I. Flugge, H.W. Heldt, A two-translocator model for the transport of 2oxoglutarate and glutamate in chloroplasts during ammonia assimilation in the light, Plant Physiol. 84 (1987) 624-632. doi:10.1104/pp.84.3.624.

[97] A. Weber, U.-I. Flügge, Interaction of cytosolic and plastidic nitrogen metabolism in plants., J. Exp. Bot. 53 (2002) 865-874. doi:10.1093/jexbot/53.370.865.

[98] M.G. Claros, M.L. Aguilar, F.M. Cánovas, Evidence for an operative glutamine translocator in chloroplasts from maritime pine ( Pinus pinaster Ait.) cotyledons, Plant Biol. 12 (2010) 717-723. doi:10.1111/j.1438-8677.2009.00274.x.

[99] C. Ávila Sáez, R. Muñoz-Chapuli, C. Plomion, J.M. Frigerio, F.M. Cánovas, Two genes encoding distinct cytosolic glutamine synthetases are closely linked in the pine genome, FEBS Lett. 477 (2000) 237-243. doi:10.1016/S0014-5793(00)01796-8.

[100] S. Dinant, J.L. Bonnemain, C. Girousse, J. Kehr, Phloem sap intricacy and interplay with aphid feeding, Comptes Rendus - Biol. 333 (2010) 504-515. doi:10.1016/j.crvi.2010.03.008.

[101] H. Hayashi, M. Chino, Collection of pure phloem sap from wheat and its chemical composition, Plant Cell Physiol. 27 (1986) 1387-1393. doi:10.1093/oxfordjournals.pcp.a077237.

[102] B.G. Forde, P.J. Lea, Glutamate in plants: Metabolism, regulation, and signalling, J. Exp. Bot. 58 (2007) 2339-2358. doi:10.1093/jxb/erm121.

[103] H.-M. Lam, J. Chiu, M.-H. Hsieh, L. Meisel, I.C. Oliveira, M. Shin, G. Coruzzi, Glutamate-receptor genes in plants., Nature. 396 (1998) 125-126. doi:10.1038/24066.

[104] C.A. Bonner, R.A. Jensen, Recognition of specific patterns of amino acid inhibition of growth in higher plants, uncomplicated by glutamine-reversible "general amino acid inhibition," Plant Sci. 130 (1997) 133-143. doi:10.1016/S0168-9452(97)00213-6.

[105] C.A. Bonner, D.S. Williams, H.C. Aldrich, R.A. Jensen, Antagonism by L-glutamine of toxicity and growth inhibition caused by other amino acids in suspension cultures of Nicotiana silvestris , Plant Sci. 113 (1996) 43-58. doi:10.1016/0168-9452(95)04284-9.

[106] P. Walch-Liu, L.H. Liu, T. Remans, M. Tester, B.G. Forde, Evidence that L-glutamate can act as an exogenous signal to modulate root growth and branching in Arabidopsis thaliana, Plant Cell Physiol. 47 (2006) 1045-1057. doi:10.1093/pcp/pcj075.

[107] B.G. Forde, P. Walch-Liu, Nitrate and glutamate as environmental cues for behavioural responses in plant roots, Plant, Cell Environ. 32 (2009) 682-693. doi:10.1111/j.13653040.2008.01927.x.

[108] D. Tapken, U. Anschütz, L. Liu, T. Huelsken, G. Seebohm, D. Becker, M. Hollmann, A plant homolog of animal glutamate receptors is an ion channel gated by multiple hydrophobic amino acids., Sci. Signal. 6 (2013) 1-10. doi:10.1126/scisignal.2003762.

[109] E. Teardo, E. Formentin, A. Segalla, G.M. Giacometti, O. Marin, M. Zanetti, F. Lo Schiavo, M. Zoratti, I. Szabó, Dual localization of plant glutamate receptor AtGLR3.4 to plastids and plasmamembrane, Biochim. Biophys. Acta - Bioenerg. 1807 (2011) 359367. doi:10.1016/j.bbabio.2010.11.008.

[110] E. Teardo, L. Carraretto, S. De Bortoli, A. Costa, S. Behera, R. Wagner, F. Lo Schiavo, E. Formentin, I. Szabo, Alternative Splicing-Mediated Targeting of the Arabidopsis GLUTAMATE RECEPTOR3.5 to Mitochondria Affects Organelle Morphology, Plant Physiol. 167 (2015) 216-227. doi:10.1104/pp.114.242602.

[111] P. Vatsa, A. Chiltz, S. Bourque, D. Wendehenne, A. Garcia-Brugger, A. Pugin, Involvement of putative glutamate receptors in plant defence signaling and NO 
production, Biochimie. 93 (2011) 2095-2101. doi:10.1016/j.biochi.2011.04.006.

[112] Y. Cheng, Q. Tian, W.-H. Zhang, Glutamate receptors are involved in mitigating effects of amino acids on seed germination of Arabidopsis thaliana under salt stress, Environ. Exp. Bot. 130 (2016) 68-78. doi:10.1016/j.envexpbot.2016.05.004.

[113] M.B. Price, J. Jelesko, S. Okumoto, Glutamate receptor homologs in plants: functions and evolutionary origins, Front. Plant Sci. 3 (2012) 235. doi:10.3389/fpls.2012.00235.

[114] B.G. Forde, Glutamate signalling in roots, J. Exp. Bot. 65 (2014) 779-787. doi:10.1093/jxb/ert335.

[115] K. Ishiyama, E. Inoue, T. Yamaya, H. Takahashi, Gln49 and Ser174 residues play critical roles in determining the catalytic efficiencies of plant glutamine synthetase, Plant Cell Physiol. 47 (2006) 299-303. doi:10.1093/pcp/pci238.

[116] E. Grygo-Szymanko, A. Tobiasz, S. Walas, Speciation analysis and fractionation of manganese: A review, Trends Anal. Chem. 80 (2016) 112-124. doi:10.1016/j.trac.2015.09.010.

[117] A. Kushwaha, N. Hans, S. Kumar, R. Rani, A critical review on speciation, mobilization and toxicity of lead in soil-microbe-plant system and bioremediation strategies, Ecotoxicol. Environ. Saf. 147 (2018) 1035-1045. doi:10.1016/j.ecoenv.2017.09.049.

[118] M. Ivarsson, C. Broman, N.G. Holm, Chromite oxidation by manganese oxides in subseafloor basalts and the presence of putative fossilized microorganisms, Geochem. Trans. 12 (2011) 1-10. doi:10.1186/1467-4866-12-5.

[119] B. Atwell, P. Kriedemann, C. Turnbull, Plants in action: adaptation in nature, performance in cultivation, MacMillan Education, 1999. $\mathrm{http} / / /$ plantsinaction.science.uq.edu.au/edition $1 /$.

[120] R. Tomioka, A. Oda, C. Takenaka, Root growth enhancement by rhizospheric aluminum treatment in Quercus serrata Thunb. seedlings, J. For. Res. 10 (2005) 319-324. doi:10.1007/s10310-005-0152-0.

[121] K.J. Mullette, Stimulation of growth in Eucalyptus due to aluminium, Plant Soil. 42 (1975) 495-499. doi:10.1007/BF00010026.

[122] T. Watanabe, S. Jansen, M. Osaki, The beneficial effect of aluminium and the role of citrate in Al accumulation in Melastoma malabathricum, New Phytol. 165 (2005) 773780. doi:10.1111/j.1469-8137.2004.01261.x.

[123] J. Navascués, C. Pérez-Rontomé, D.H. Sánchez, C. Staudinger, S. Wienkoop, R. RellánÁlvarez, M. Becana, Oxidative stress is a consequence, not a cause, of aluminum toxicity in the forage legume Lotus corniculatus, New Phytol. 193 (2012) 625-636. doi:10.1111/j.1469-8137.2011.03978.x.

[124] É. Darkó, H. Ambrus, É. Stefanovits-Bányai, J. Fodor, F. Bakos, B. Barnabás, Aluminium toxicity, $\mathrm{Al}$ tolerance and oxidative stress in an Al-sensitive wheat genotype and in Al-tolerant lines developed by in vitro microspore selection, Plant Sci. 166 (2004) 583-591. doi:10.1016/j.plantsci.2003.10.023.

[125] F. Zsoldos, Á. Vashegyi, L. Bóna, A. Pécsváradi, Z. Szegletes, Aluminium and nitrite induced alteration in potassium transport of wheat, Cereal Res. Commun. 27 (1999) 147-153. https://www.jstor.org/stable/23786278.

[126] A. Pécsváradi, Z. Nagy, A. Varga, Á. Vashegyi, I. Labdi, G. Galbács, F. Zsoldos, Chloroplastic glutamine synthetase is activated by direct binding of aluminium, Physiol. Plant. 135 (2009) 43-50. doi:10.1111/j.1399-3054.2008.01167.x.

[127] N. Yamaji, C.F. Huang, S. Nagao, M. Yano, Y. Sato, Y. Nagamura, J.F. Ma, A zinc finger transcription factor ART1 regulates multiple genes implicated in aluminum tolerance in rice, Plant Cell. 21 (2009) 3339-3349. doi:10.1105/tpc.109.070771.

[128] J. Xia, N. Yamaji, T. Kasai, J.F. Ma, Plasma membrane-localized transporter for aluminum in rice, Proc. Natl. Acad. Sci. 107 (2010) 18381-18385. doi:10.1073/pnas.1004949107.

[129] O.A. Hoekenga, L.G. Maron, M.A. Pineros, G.M.A. Cancado, J. Shaff, Y. Kobayashi, P.R. Ryan, B. Dong, E. Delhaize, T. Sasaki, H. Matsumoto, Y. Yamamoto, H. Koyama, L. V. Kochian, AtALMT1, which encodes a malate transporter, is identified as one of several genes critical for aluminum tolerance in Arabidopsis, Proc. Natl. Acad. Sci. 103 
(2006) 9738-9743. doi:10.1073/pnas.0602868103.

[130] Y. Wang, R. Li, D. Li, X. Jia, D. Zhou, J. Li, S.M. Lyi, S. Hou, Y. Huang, L. V. Kochian, J. Liu, NIP1;2 is a plasma membrane-localized transporter mediating aluminum uptake, translocation, and tolerance in Arabidopsis, Proc. Natl. Acad. Sci. 114 (2017) 5047-5052. doi:10.1073/pnas.1618557114.

[131] L. V. Kochian, O.A. Hoekenga, M.A. Piñeros, How do crop plants tolerate acid soils? Mechanisms of aluminum tolerance and phosphorous efficiency, Annu. Rev. Plant Biol. 55 (2004) 459-493. doi:10.1146/annurev.arplant.55.031903.141655.

[132] F.C.B. Zambrosi, G.L. Mesquita, P.E.R. Marchiori, F.A.O. Tanaka, E.C. Machado, R.V. Ribeiro, Anatomical and physiological bases of sugarcane tolerance to manganese toxicity, Environ. Exp. Bot. 132 (2016) 100-112. doi:10.1016/j.envexpbot.2016.08.011.

[133] M. Lou Guerinot, The ZIP family of metal transporters, Biochim. Biophys. Acta Biomembr. 1465 (2000) 190-198. doi:10.1016/S0005-2736(00)00138-3.

[134] S.A. Kim, T. Punshon, A. Lanzirotti, A. Li, J.M. Alonso, J.R. Ecker, J. Kaplan, M. Lou Guerinot, Localization of iron in Arabidopsis seed requires the vacuolar membrane transporter VIT1, Science (80-. ). 314 (2006) 1295-1298. doi:10.1126/science.1132563.

[135] P.A. Salomé, Manganese is a plant's best friend: intracellular Mn transport by the transporter NRAMP2, Plant Cell. 29 (2017) tpc.00965.2017. doi:10.1105/tpc.17.00965.

[136] J.F. Shao, N. Yamaji, R.F. Shen, J.F. Ma, The key to Mn homeostasis in plants: regulation of Mn transporters, Trends Plant Sci. 22 (2017) 215-224. doi:10.1016/j.tplants.2016.12.005.

[137] F. Zsoldos, E. Haunold, A. Vashegyi, The effects of phosphate supply on uptake of potassium ions, 2,4-D and atrazine by wheat and maize, Physiol. Plant. 68 (1986) 154158. doi:10.1111/j.1399-3054.1986.tb06611.x.

[138] M.M. Bradford, A rapid and sensitive method for the quantitation of microgram quantities of protein utilizing the principle of protein-dye binding, Anal. Biochem. 72 (1976) 248-254. doi:10.1016/0003-2697(76)90527-3.

[139] U.K. Laemmli, Cleavage of structural proteins during the assembly of the head of bacteriophage T4., Nature. 227 (1970) 680-5. doi:10.1038/227680a0.

[140] H. Schägger, G. von Jagow, Tricine-sodium dodecyl sulfate-polyacrylamide gel electrophoresis for the separation of proteins in the range from 1 to $100 \mathrm{kDa}$., Anal. Biochem. 166 (1987) 368-379. doi:10.1016/0003-2697(87)90587-2.

[141] M.J. Bennett, J. V. Cullimore, Glutamine synthetase isoenzymes of Phaseolus vulgaris L.: subunit composition in developing root nodules and plumules, Planta. 179 (1989) 433-440. doi:10.1007/BF00397582.

[142] J. V. Cullimore, B.J. Miflin, Immunological studies on glutamine synthetase using antisera raised to the two plant forms of the enzyme from Phaseolusroot nodules, J. Exp. Bot. 35 (1984) 581-587. doi:10.1093/jxb/35.4.581.

[143] V. Neuhoff, R. Stamm, H. Eibl, Clear background and highly sensitive protein staining with Coomassie Blue dyes in polyacrylamide gels: A systematic analysis, Electrophoresis. 6 (1985) 427-448. doi:10.1002/elps.1150060905.

[144] N. Lehotai, Z. Kolbert, A. Pető, G. Feigl, A. Ördög, D. Kumar, I. Tari, L. Erdei, Selenite-induced hormonal and signalling mechanisms during root growth of Arabidopsis thaliana L., J. Exp. Bot. 63 (2012) 5677-5687. doi:10.1093/jxb/ers222.

[145] G.R. Stewart, D. Rhodes, A comparison of the charecteristics of glutamine synthetase and glutamate dehydrogenase from Lemna minor L., New Phytol. 79 (1977) 257-268. doi:10.1111/j.1469-8137.1977.tb02203.x.

[146] V. De Col, P. Fuchs, T. Nietzel, M. Elsässer, C.P. Voon, A. Candeo, I. Seeliger, M.D. Fricker, C. Grefen, I.M. Møller, A. Bassi, B.L. Lim, M. Zancani, A.J. Meyer, A. Costa, S. Wagner, M. Schwarzländer, ATP sensing in living plant cells reveals tissue gradients and stress dynamics of energy physiology, Elife. 6 (2017) 1-29. doi:10.7554/eLife.26770.

[147] E. Németh, Z. Nagy, A. Pécsváradi, Chloroplast Glutamine Synthetase , the Key Regulator of Nitrogen Metabolism in Wheat, Performs Its Role by Fine Regulation of Enzyme Activity via Negative Cooperativity of Its Subunits, Front. Plant Sci. 9 (2018) 
191. doi:10.3389/fpls.2018.00191.

[148] B.M. Shapiro, E.R. Stadtman, The regulation of glutamine synthesis in microorganisms, Annu. Rev. Microbiol. 24 (1970) 501-24. doi:10.1146/annurev.mi.24.100170.002441.

[149] T.F. Deuel, S. Prusiner, Regulation of glutamine synthetase from Bacillus subtilis by divalent cations, feedback Inhibitors, and L-glutamine, J. Biol. Chem. 249 (1974) 257264.

[150] X. Wang, Y. Wei, L. Shi, X. Ma, S.M. Theg, New isoforms and assembly of glutamine synthetase in the leaf of wheat (Triticum aestivum L.), J. Exp. Bot. 66 (2015) 6827 6834. doi:10.1093/jxb/erv388.

[151] K. van Eunen, J.A.L. Kiewiet, H. V. Westerhoff, B.M. Bakker, Testing biochemistry revisited: How in vivo metabolism can be understood from in vitro enzyme kinetics, PLoS Comput. Biol. 8 (2012). doi:10.1371/journal.pcbi.1002483.

[152] S.S. Tate, a Meister, Regulation of rat liver glutamine synthetase: activation by alphaketoglutarate and inhibition by glycine, alanine, and carbamyl phosphate., Proc. Natl. Acad. Sci. U. S. A. 68 (1971) 781-785. doi:10.1073/pnas.68.4.781.

[153] W. Bielawski, Purification and partial characterization of glutamine synthetase isoforms from Triticale seedlings.pdf, Acta Biochim. Pol. 41 (1994) 397-404. 


\section{Mellékletek}

I. melléklet:

A táblázat a magyarországi (a) búzatermésre és (b) mütrágya felhasználásra vonatkozó adatokat mutatja. Az adatok rendre a Központi Statisztikai Hivatal 2017.10.20. és 2017.11.10.-i adatai, melyek a következő linkeken keresztül érhetők el:

https://www.ksh.hu/docs/hun/xstadat/xstadat_eves/i_omn001a.html

https://www.ksh.hu/docs/hun/xstadat/xstadat_eves/i_tal001b.html

(a)

\begin{tabular}{|c|c|c|c|}
\hline & $\mathbf{2 0 1 4}$ & $\mathbf{2 0 1 5}$ & $\mathbf{2 0 1 6}$ \\
\hline Termés adatok & & & \\
\hline Betakarított terület (ha) & 1112730 & 1029318 & 1044314 \\
\hline Betakarított összes termés (t) & 5261890 & 5331426 & 5603184 \\
\hline Termésátlag (kg/ha) & 4730 & 5180 & 5370 \\
\hline Felhasználás (t) & & & \\
\hline Ipari feldolgozás & 1145008 & 1172413 & 1216968 \\
\hline Takarmányfelhasználás & 1150817 & 1187686 & 1163076 \\
\hline Vetőmag-felhasználás & 258240 & 262548 & 241665 \\
\hline Kivitel & 2483431 & 1962562 & 2764795 \\
\hline
\end{tabular}

(b)

\begin{tabular}{|c|c|c|c|c|c|c|}
\hline Nitrogén bevitel (ezer t) & $\mathbf{2 0 1 1}$ & $\mathbf{2 0 1 2}$ & $\mathbf{2 0 1 3}$ & $\mathbf{2 0 1 4}$ & $\mathbf{2 0 1 5}$ & $\mathbf{2 0 1 6}$ \\
\hline műtrágyázással & 302,6 & 313,5 & 343,7 & 327,2 & 358,9 & 366,0 \\
\hline $\begin{array}{c}\text { szervestrágyázással } \\
\text { egyéb (légköri ülepedés, } \\
\text { nitrogén kötés, } \\
\text { szaporítóanyagok) }\end{array}$ & 718,9 & 118,5 & 120,0 & 123,9 & 128,8 & 129,2 \\
\hline összesen & 496,7 & 504,8 & 546,1 & 544,4 & 573,9 & 585,2 \\
\hline
\end{tabular}


II. melléklet:

A magyarországi szánóterületek, a területek belvíz kitettsége és a talajok kémhatása. Az eredeti térképek elérhetők a Nemzeti Élelmiszerbiztonsági Hatóság honlapján keresztül. A források a térképek alatt.

(a): Magyarország talajainak vízgazdálkodása:

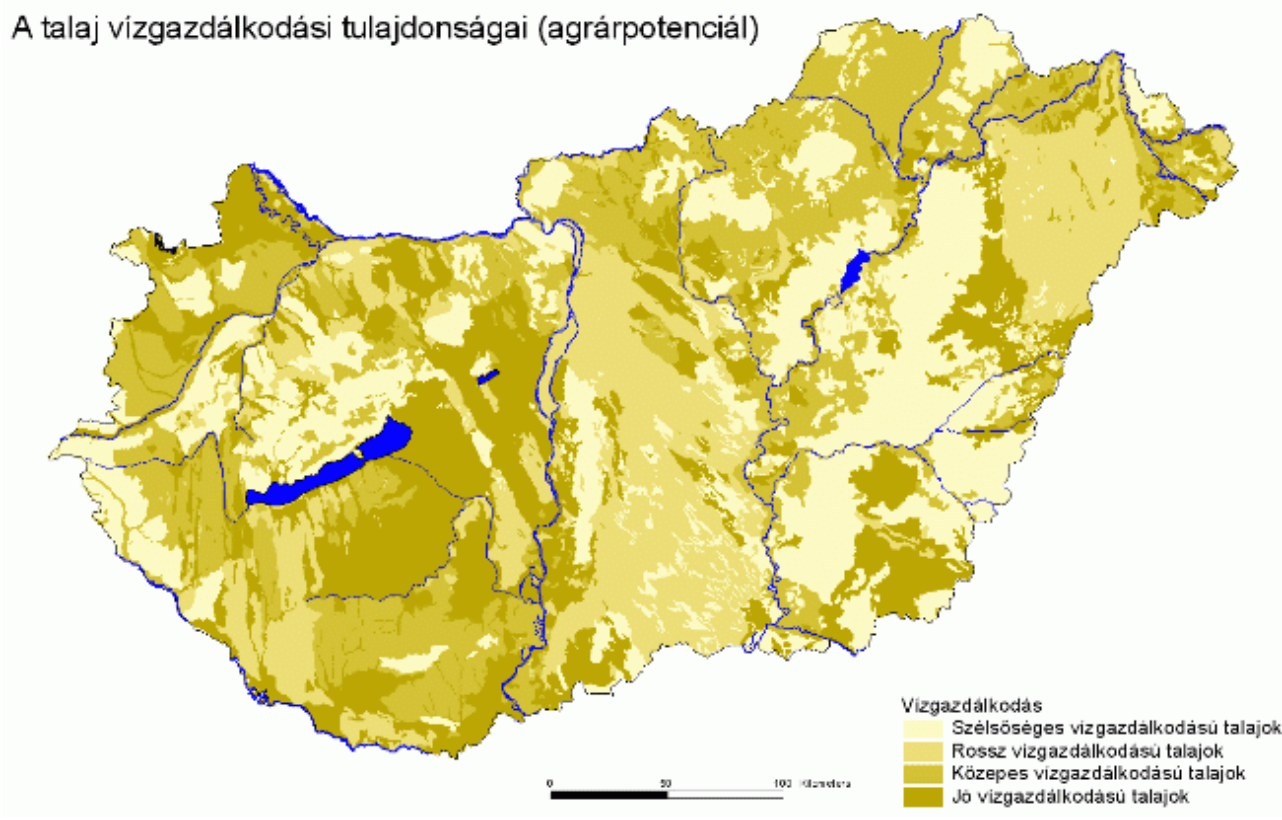

http://enfo.agt.bme.hu/drupal/sites/default/files/vízgazálkodás.gif

(b) A talajok kémhatása Magyarországon:

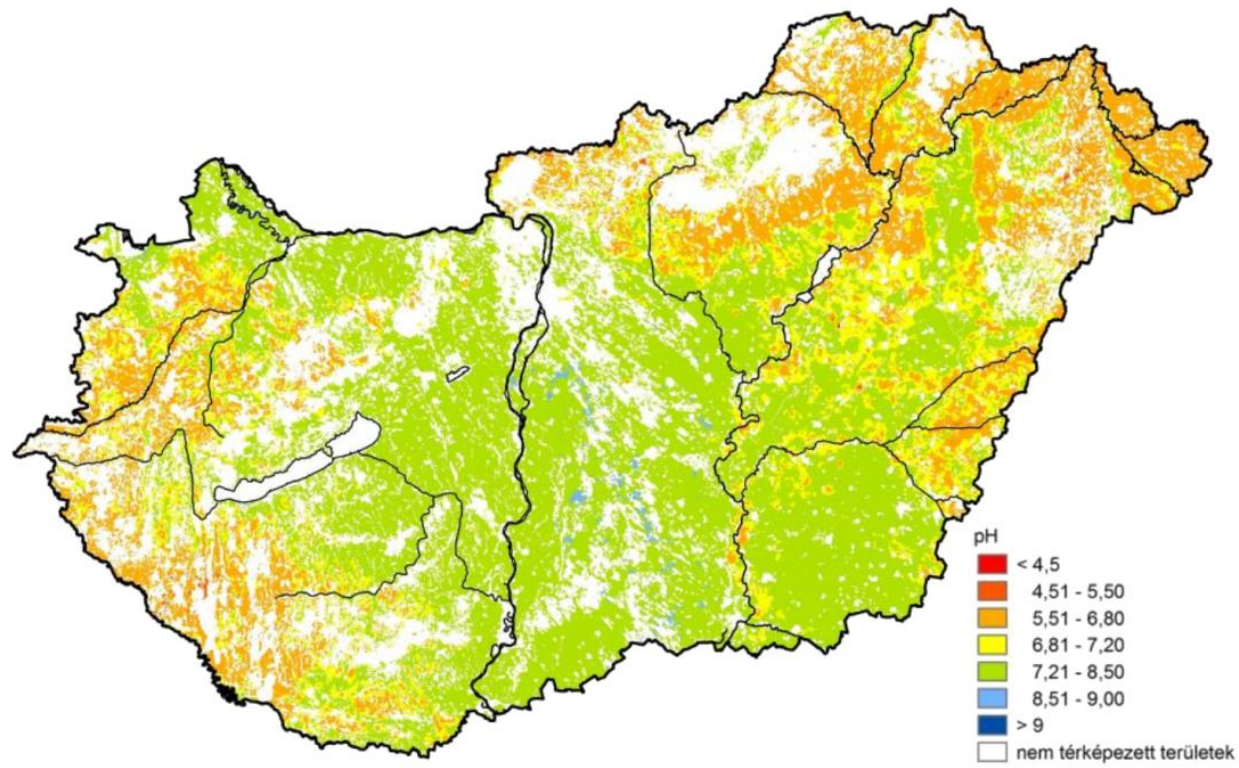

http://airterkep.nebih.gov.hu/gis_portal/talajvedelem/pdf/LB-NA-27539-HU-N_online.pdf 
(c): Magyarország területhasználata:

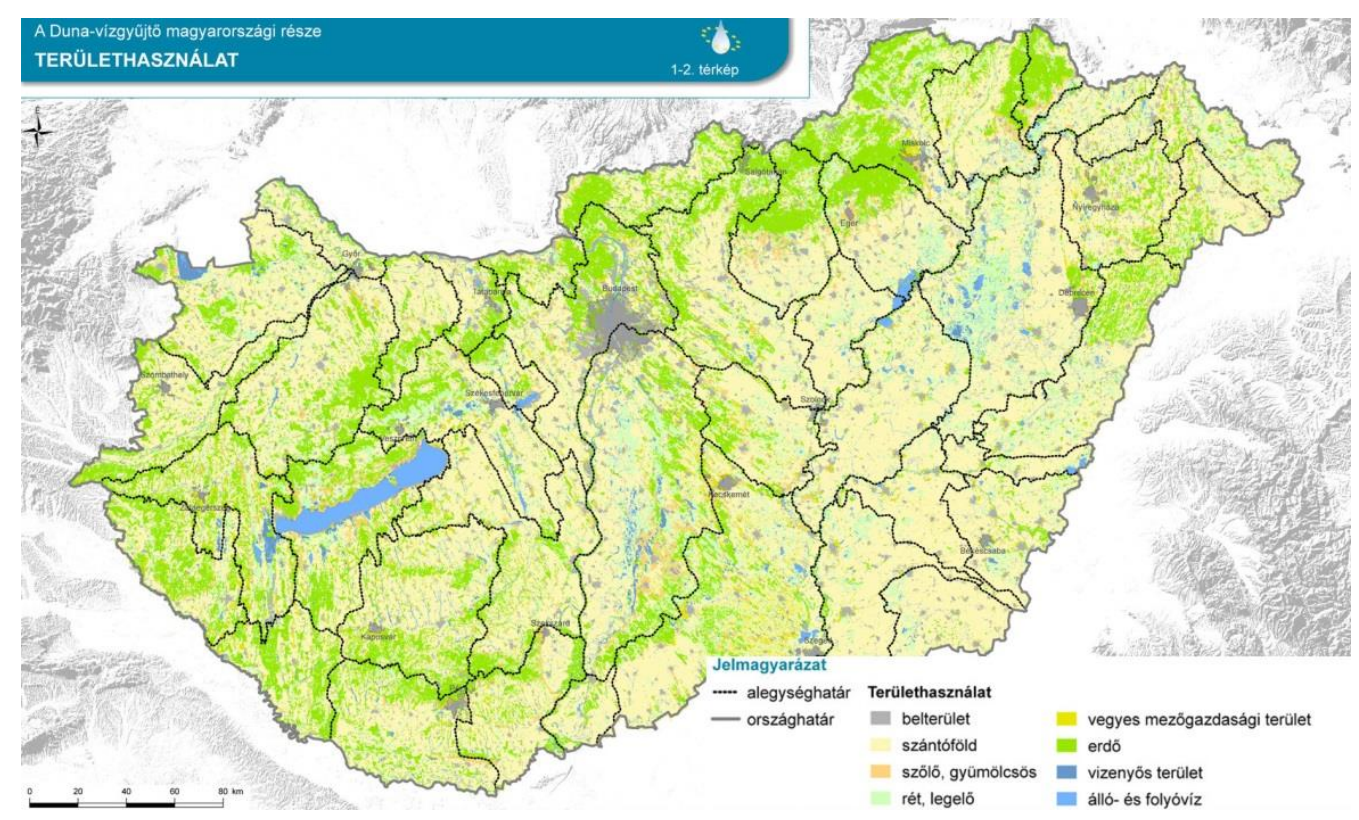

http://enfo.agt.bme.hu/drupal/sites/default/files/orsz_0102kicsibb.jpg

III. melléklet:

A 12. ábrán bemutatott hidroxilamin szaturációs görbékre illesztett Michaelis-Menten egyenlet paraméterei.

\begin{tabular}{ccc}
\hline $\begin{array}{c}\text { Glutaminsav } \\
(\mathrm{mM})\end{array}$ & $\begin{array}{c}\mathrm{V}_{\max } \pm \mathrm{SE} \\
\left(\mathrm{nkat} \mathrm{g}^{-1} \mathrm{FW}\right)\end{array}$ & $\begin{array}{c}\mathrm{K}_{\mathrm{s}} \pm \mathrm{SE} \\
(\mathrm{mM})\end{array}$ \\
\hline \hline 1 & $0,41 \pm 0,01$ & $2,00 \pm 0,27$ \\
3,5 & $0,67 \pm 0,01$ & $1,07 \pm 0,09$ \\
8 & $0,83 \pm 0,01$ & $1,23 \pm 0,11$ \\
30 & $1,41 \pm 0,03$ & $1,45 \pm 0,14$ \\
\hline
\end{tabular}

SE: „standard error” az illesztett görbétől való eltérés alapján a program által számított érték 
IV. melléklet:

A 13. ábrán bemutatott ATP szaturációs görbékre illesztett Michaelis-Menten egyenlet paraméterei. A görbeillesztést a gátlás fellépéséig illesztettük, feltételezve, hogy a telítettség eléréséig nem lép fel allosztérikus gátlás.

\begin{tabular}{ccc}
\hline $\begin{array}{c}\text { Glutaminsav } \\
(\mathrm{mM})\end{array}$ & $\begin{array}{c}\mathrm{V}_{\max } \pm \mathrm{SE} \\
\left(\text { nkat }^{-1} \mathrm{FW}\right)\end{array}$ & $\begin{array}{c}\mathrm{K}_{\mathrm{s}} \pm \mathrm{SE} \\
(\mathrm{mM})\end{array}$ \\
\hline \hline 1 & $0,32 \pm 0,02$ & $0,94 \pm 0,24$ \\
3,5 & $0,69 \pm 0,03$ & $1,44 \pm 0,23$ \\
8 & $1,09 \pm 0,03$ & $2,11 \pm 0,20$ \\
30 & $2,06 \pm 0,03$ & $3,49 \pm 0,14$ \\
\hline
\end{tabular}

SE: „standard error” az illesztett görbétől való eltérés alapján a program által számított érték

V. melléklet:

A tisztított GS2 glutaminsav szaturációs görbéjére (14. ábra) illesztett alapmodellek SigmaPlot® segítségével számított statisztikai kimenete:

\begin{tabular}{lcc}
\hline \multicolumn{1}{c}{ Egyenlet } & AICc & $\mathrm{R}_{c}$ \\
\hline \hline Hill & 5.393 & 0.99242 \\
Michaelis-Menten & 17.553 & 0.98096 \\
Szubsztrátum Aktiváció (Random) & 21.040 & 0.98096 \\
Szubsztrátum Gátlás & & \\
(Uncompetitive) & 21.041 & 0.98096 \\
Szubsztrátum Aktiváció (Ordered) & 21.153 & 0.98083 \\
\hline
\end{tabular}


VI.. számú melléklet:

Az alkalmazott tisztítási metódus hatékonyságának ellenőrzése SDS denaturáló gél elektroforézissel. A szeparálást az „Anyagok és módszerek” fejezetben ismertetett SDS PAGE módszer szerint hajtottuk végre. A mintafelvitelhez használt minta felvivő puffer összetétele a következöképpen alakult: $150 \mathrm{mM}$ Tris-HCl pH 6,8, 6,8\% SDS, $11 \%$ glicerin, $6 \% \beta$-merkaptoetanol. A minta : mintapuffer aránya $2: 1$ volt. A tisztított GS2 oldat fehérje végkoncentrációja $0.028 \mu \mathrm{g} / \mu \mathrm{l}$ volt.

A futtatás után CBBG festéssel tettük láthatóvá a fehérjéket, mely az alábbi képen látható. A molekulasúlymarkerek balról $(\mathrm{kDa})$ jelölve. A további jelölések értelmezése a következő: 1.: Minta felvivő puffer; 2.: molekulasúly marker; 3-4.: $1 \mu \mathrm{g}$ és 1,3 $\mu \mathrm{g}$ tisztított GS2; 5.:12 $\mu \mathrm{g}$ nyers fehérje kivonat levélböl.

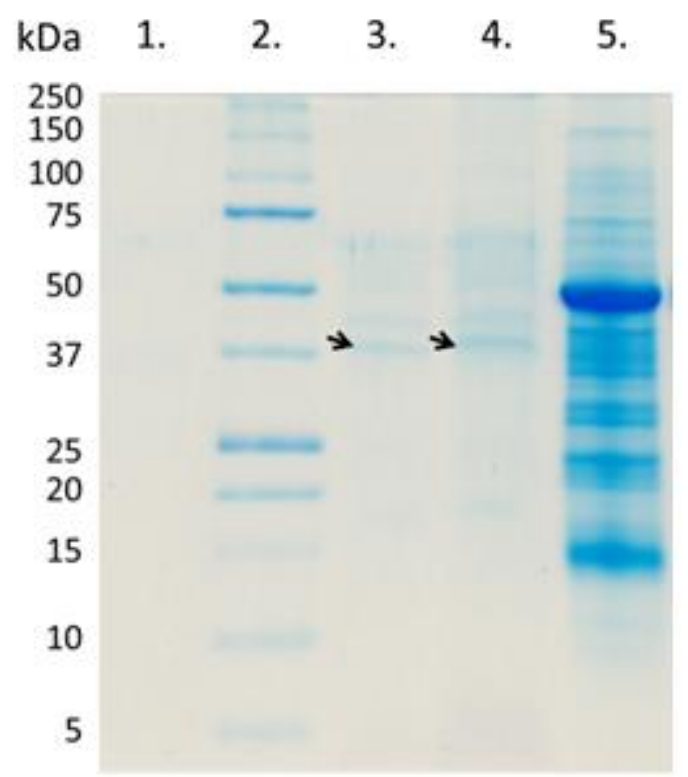

VII.: A hígítást és albumin kezelést alkalmazó kísérletek 17. ábrán feltüntetett eredményeinek kinetikai paraméterei:

\begin{tabular}{cccc}
\hline Hígítás & $\begin{array}{c}\mathrm{V}_{\max } \\
(\text { nkat g-1 } \mathrm{FW})\end{array}$ & $\begin{array}{c}\mathrm{K}_{\mathrm{s}} \\
(\mathrm{mM})\end{array}$ & $\mathrm{n}$ \\
\hline \hline $1 \mathrm{x}$ & $2.46 \pm 0.07$ & $28.97 \pm 2.21$ & $0.88 \pm 0.02$ \\
5x A- & $3.01 \pm 0.06$ & $41.15 \pm 2.43$ & $0.88 \pm 0.02$ \\
5x A+ & $3.27 \pm 0.10$ & $45.50 \pm 3.65$ & $0.87 \pm 0.02$ \\
\hline
\end{tabular}




\section{Publikációs lista}

\section{Referált folyóiratban megjelent tudományos közlemények:}

(A doktori eljárás alapját képezö közlemények *-gal jelölve))

* Németh, E., Nagy Z., Pécsváradi, A.: Chloroplast glutamine synthetase, the key regulator of nitrogen metabolism in wheat, performs its role by fine regulation of enzyme activity via negative cooperativity of its subunits. Frontiers in Plant Science (9):191 (2018) DOI: $10.3389 /$ fpls.2018.00191

$$
\mathrm{IF}_{2016}: 4,298
$$

Pál, M., Majláth, I., Németh, E., Hamow, K., Á., Szalai, G., Rudnóy, Sz., Balassa, Gy., Janda, T.: The effects of putrescine are partly overlapping with osmotic stress processes in wheat. Plant Science 268: pp. 67-76. (2018) DOI: 10.1016/j.plantsci.2017.12.011

$\mathrm{IF}_{2016}: 3,437$

Horvath, B.,M., Kourova, H., Nagy, S., Németh E., Magyar, Z., Papdi, C., Ahmad, Z., Sanchez-Perez, G.,F., Perilli, S., Blilou, I., Pettkó-Szandtner, A., Darula, Z., Meszaros, T., Binarova, P., Bogre, L., Scheres, B.: Arabidopsis RETINOBLASTOMA RELATED directly regulates DNA damage responses through functions beyond cell cycle control. EMBO Journal 36:(9) 1261-1278. (2017) DOI: 10.15252/embj.201694561

$\mathrm{IF}_{2016}: 9,792$

Pál, M., Csávás, G., Szalai, G., Oláh T., Khalilc, R., Yordanovad, R., Gell, G, Birinyi, Z., Németh, E., Janda, T.: Polyamines may influence phytochelatin synthesis during Cd stress in rice. Journal of Hazardous Materials 340: 272-280 (2017) DOI: $10.1016 /$ j.jhazmat.2017.07.016

$$
\mathrm{IF}_{2016}: 6,065
$$

Benyó, D., Horváth, E., Németh, E., Leviczky, T., Takács, K., Lehotai, N., Feigl, G., Kolbert, Zs., Ördög A., Gallé, R., Csiszár, J., Szabados, L., Erdei, L., Gallé, Á.: Physiological and molecular responses to heavy metal stresses suggest different detoxification mechanism of Populus deltoides and P. x canadensis. Journal of Plant Physiology 201: 62-70. (2016) DOI: 10.1016/j.jplph.2016.05.025

$\mathrm{IF}_{2016}: 3,121$

*Nagy, Z., Németh, E., Guóth, A., Bona, L., Wodala, B., Pécsváradi, A.,: Metabolic indicators of drought stress tolerance in wheat: Glutamine synthetase isoenzymes and Rubisco. Plant Physiology and Biochemistry 67:48-54 (2013) DOI: 10.1016/j.plaphy.2013.03.001

$\mathrm{IF}_{2013}: 2,724$ 


\section{Egyéb szakmai anyagok:}

Konferencián tartott magyar nyelvü elöadás (elöadó):

Németh, E., Bónus, L., Pécsváradi, A.: Binding of manganese to chloroplast glutamine synthetase and its effect on enzyme activity in wheat. Fiatal Biotechnológusok Országos Konferenciája (FIBOK), Budapest, március 28-29., 2018

Németh, E., Molnár, R., Nagy, Z., Pécsváradi, A.: Az alumínium aktiválja a plasztidikus glutamin-szintetázt. Tavaszi Szél Konferencia, Debrecen, március 21-23., 2014

Konferencián tartott angol nyelvü elöadás (elöadó):

Németh, E., Nagy, Z., Benyó, D., Pécsváradi, A.,:Comparison of copper treated poplar (Populus sp.) clones. HUSRB/1002/214/036 Oxidative stress tolerance in plants: from models to trees, IPA OXIT Conference, Novi Sad, Serbia, november 14-15, 2013

Nagy, Z., Németh, E., Pécsváradi, A.: Separation of protein content of stressed poplar leaves by two-dimensional polyacrylamide gel electrophoresis. HUSRB/1002/214/036 „OXIT” Characterization and oxidative stress tolerance in plants: from models to trees, Interim Conference, Szeged, Hungary November 20, 2012

Németh, E., Pécsváradi, A.: Nitrogen assimilation in plants: glutamine synthetase isoforms with special roles. HUSRB/1203/221/173 „PLANTTRAIN” Seminar and Workshops in Szeged Of the Hungary-Serbia IPA Cross-border Cooperation Programme, Szeged, Hungary August 31-september 4, 2015

\section{Konferencia elöadás (társszerzö):}

Pécsváradi, A., Nagy, Z., Németh, E.: Changes in glutamine synthetase activity and in protein pattern of wheat leaves after Fusarium infection (lecture). Third Progress Meeting Szeged-Timisoara axis for the safe food and feed SZETISA1 Hungary-Romania CrossBorder Cooperation Programme 2007-2013 HURO/0901/147/2.2.2. Timisoara, January 2627, 2012.

Nagy, Z., Németh, E., Gallé, Á., Csiszár, J., Erdei, L., Pécsváradi, A.: Changes in nitrogen metabolism of different wheat cultivars following Fusarium infection. HURO/0901/147/2.2.2 Szeged - Timişoara axis for the safe food and feed (SZETISA1) Hungary-Romania CrossBorder Co-operation Programme 2007-2013 Szeged, Hungary May $15-16,2012$

\section{Publikáció (Konferenciakötet):}

Nagy Z., Németh E., Gallé Á., Csiszár J., Erdei L., Pécsváradi A.: Changes in nitrogen metabolism of different wheat cultivars following Fusarium infection. Book of Final Riport HURO/0901/1472.2.2. Szeged - Timişoara axis for the safe food and feed SZETISA1, 2012

Németh, E., Nagy, Z., Benyó, D., Pécsváradi, A.,:Comparison of copper treated poplar (Populus sp.) clones. HUSRB/1002/214/036 Characterization and oxidative stress tolerance in plants: from models to trees „OXIT” Book of Final Report, 2013 


\section{Absztrakt (Konferenciakiadvány)}

Németh, E., Bónus, L., Pécsváradi, A.: Binding of manganese to chloroplast glutamine synthetase and its effect on enzyme activity in wheat. FIBOK - Fiatal Biotechnológusok Országos Konferenciája, 2018

Németh, E., Végh, B., Darkó, É., Majláth, I.: Impact of combined abiotic stress conditions on nitrogen metabolism of crop plants, A Magyar Növénybiológiai Társaság XII. Kongresszusa, Szeged, augusztus 30.-szeptember 1., 2017

Majláth I, Darko E, Végh B, Németh E., Nagy Z.: The response to moderate drought on the light utilisation of crop plants at suboptimal temperature, A Magyar Növénybiológiai Társaság XII. Kongresszusa, Szeged, augusztus 30.-szeptember 1., 2017

Németh, E., Nagy, Z., Benyó, D., Pécsváradi, A.,:Comparison of copper treated poplar (Populus sp.) clones. HUSRB/1002/214/036 Oxidative stress tolerance in plants: from models to trees, IPA OXIT Conference, Book of abstracts, Novi Sad, Serbia, 2013

Nagy, Z., Németh, E., Pécsváradi, A.: Separation of protein content of stressed poplar leaves by two-dimensional p olyacrylamide gel electrophoresis. HUSRB/1002/214/036 „OXIT” Characterization and oxidative stress tolerance in plants: from models to trees, Programme and interim Conference, Book of abstracts, Szeged, 2012

\section{Konferencián bemutatott poszterek:}

Németh, E., Végh, B., Darkó, É., Majláth, I.: Impact of combined abiotic stress conditions on nitrogen metabolism of crop plants, A Magyar Növénybiológiai Társaság XII. Kongresszusa, Szeged, augusztus 30.-szeptember 1., 2017

Majláth I, Darko E, Végh B, Németh E., Nagy Z.: The response to moderate drought on the light utilisation of crop plants at suboptimal temperature, A Magyar Növénybiológiai Társaság XII. Kongresszusa, Szeged, augusztus 30.-szeptember 1., 2017

Németh, E., Nagy, Z., Pécsváradi, A.: Copper treatment induced alterations in poplar leaf proteom. A Magyar Növénybiológiai Társaság XI. Kongresszusa, 2014. augusztus 27.-29., Szeged, Magyarország

Nagy, Z., Péter Szabó, K., Németh, E., Pécsváradi, A.: Glutamine synthetase isoenzymes of Nicotiana tabacum callus of leaf origin, A Magyar Növénybiológiai Társaság X. Kongresszusa, 2011. augusztus 31. - szeptember 2., Szeged, Magyarország 


\section{Köszönetnyilvánítás}

Rendkívül hálás vagyok témavezetőmnek, Dr. Pécsváradi Attilának. Köszönöm a segítségét, a türelmét, valamint azt a tudást, nyitott gondolkodásmódot, amit az Ö tudományos műhelyében elsajátíthattam, mely végigkísérhet szakmai utamon.

Köszönettel tartozom Dr. Nagy Zoltánnak, hogy segítette első szárnypróbálgatásaimat a laboratóriumban.

Nagyra értékelem rendkívül tehetséges, lelkes egykori szakdolgozónk, Bónus Lilla munkáját, aki megbízható és pontos munkájával az én munkámat is segítette.

Mindig hálás leszek Dr. Avissar Yael önzetlen segítségéért, hogy finomította első kéziratom nyelvi esetlenségeit, és hogy mindig a rendelkezésemre állt.

Köszönöm az MTA-ATK Növényélettani Osztály minden munkatársának támogatását, odaadó segítségét.

Köszönöm az SZTE Növénybiológiai Tanszék volt és jelenlegi dolgozóinak a segítséget, és azt a családias légkört, amiben a doktorandusz éveimet tölthettem.

Köszönöm Dr. M. Horváth Beatrixnak első angol nyelvü kéziratom elkészítésekor nyújtott kritikai szakmai hozzászólásokat, mely emelhette bemutatott munkám színvonalát. De ettől még többre értékelem a barátságát, lelki támogatását és páratlan példamutatását.

Hálás vagyok szüleimnek és a páromnak a támogatásukért és a belém vetett hitükért, bizalmukért. Köszönöm szeretett barátaim népes táborának, Dugmonits Krisztinának, Farkas Gabriellának, Hajba Nikolettnek, Gál Erzsébetnek, Zakar Tamásnak és párjaiknak, valamint Bakacsy Lászlónak, a „Bernula családnak”, Takács Zoltánnak, Bela Krisztinának, Borbély Péternek és meg nem nevezett barátaimnak, akik a legnehezebb időkben is mellettem álltak, meghallgattak, kitartásra ösztökéltek, buzdítottak és számíthattam a segítségükre. Ök külön fejezetet érdemelnének. 


\section{Nyilatkozat}

Mint az alább felsorolt tudományos publikációk felelős szerzője hozzájárulok ahhoz, hogy Németh Edit a PhD fokozatszerzési eljárásában felhasználja azokat, első szerzőként, ill. társszerzőként.

* Németh, E., Nagy Z., Pécsváradi, A.: Chloroplast glutamine synthetase, the key regulator of nitrogen metabolism in wheat, performs its role by fine regulation of enzyme activity via negative cooperativity of its subunits. Frontiers in Plant Science (9):191 (2018) DOI: $10.3389 /$ fpls.2018.00191

*Nagy, Z., Németh, E., Guóth, A., Bona, L., Wodala, B., Pécsváradi, A.,: Metabolic indicators of drought stress tolerance in wheat: Glutamine synthetase isoenzymes and Rubisco. Plant Physiology and Biochemistry 67:48-54 (2013) DOI: 10.1016/j.plaphy.2013.03.001

Mindkét felhasználni kívánt publikációban, a kutatási eredmények elérésében, a kézirat elkészítésében a jelöltnek igen jelentős szerepe volt.

Szeged, 2018. május 24.

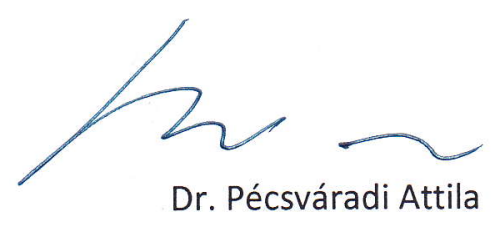

